\title{
WestVirginiaUniversity
}

THE RESEARCH REPOSITORY @ WVU

Graduate Theses, Dissertations, and Problem Reports

2021

\section{Three Essays in Regional Economics}

\author{
Zachary Keeler \\ West Virginia University, ztk0001@mix.wvu.edu
}

Follow this and additional works at: https://researchrepository.wvu.edu/etd

Part of the Agricultural and Resource Economics Commons, and the Environmental Studies Commons

\section{Recommended Citation \\ Keeler, Zachary, "Three Essays in Regional Economics" (2021). Graduate Theses, Dissertations, and Problem Reports. 8112.}

https://researchrepository.wvu.edu/etd/8112

This Dissertation is protected by copyright and/or related rights. It has been brought to you by the The Research Repository @ WVU with permission from the rights-holder(s). You are free to use this Dissertation in any way that is permitted by the copyright and related rights legislation that applies to your use. For other uses you must obtain permission from the rights-holder(s) directly, unless additional rights are indicated by a Creative Commons license in the record and/ or on the work itself. This Dissertation has been accepted for inclusion in WVU Graduate Theses, Dissertations, and Problem Reports collection by an authorized administrator of The Research Repository @ WVU.

For more information, please contact researchrepository@mail.wvu.edu. 


\title{
Three Essays in Regional Economics
}

\author{
Zachary Thomas Keeler \\ Dissertation submitted \\ to the Davis College of Agriculture, Natural Resources and Design \\ at West Virginia University \\ in partial fulfillment of the requirements \\ for the degree of \\ Doctor of Philosophy in \\ Natural Resource Economics \\ Heather Stephens, Ph.D., Chair \\ Xiaoli Etienne, Ph.D. \\ Brad Humphreys, Ph.D. \\ Peter Schaeffer, Ph.D. \\ Division of Resource Economics and Management
}

Morgantown, West Virginia

2021

Keywords: regional and urban economics, applied econometrics, housing, natural resources, urban development

Copyright 2021 Zachary Keeler 


\title{
ABSTRACT \\ Three Essays in Regional Economics
}

\author{
Zachary Thomas Keeler
}

This dissertation consists of three essays that use applied econometric analysis and other analytical methods from various economic fields, including regional and urban economics, natural resource economics, housing economics, and sports economics. In all three essays, I use housing data to value various amenities and disamenities. Using several variations on the hedonic method, I am able to uncover the values based on the capitalization effect. I consider the effect of natural resource development by examining shale gas development, as well as the effect of urban development projects, including public transportation and sports facilities.

In the first essay of my dissertation, I assess the how shale gas development affects property values in West Virginia. Overall, my paper makes at least three contributions to the literature: 1) examining the impact of new shale development in a region with a long history of resource extraction and economic distress, 2) studying later periods than in other related research, and 3) using a methodology that deals with using hedonic pricing methods in a sparse housing market. I find that the price of nearby houses decreases as the number of surrounding wells increases. I also find some evidence that this effect varies over time and that the negative capitalization effect attenuates over space.

In my second essay, I analyze how new metro lines in Los Angeles are capitalized into nearby house prices. The complex housing markets of Los Angeles allow me to assess this effect in different neighborhoods that may not value access to metro lines the same. Using a hedonic difference-in-differences approach, I find that the capitalization effect does vary. Some residents value living near new metro stations, especially those in lower/middle income areas who are more likely to use public transportation, while others do not.

In the third and final essay of my dissertation, I assess the amenity value of sports facilities. Specifically, I examine the capitalization effect on housing values of proximity to the Staples Center in Los Angeles, which is the most intensely utilized professional sports venue in the United States. Results indicate that the arena opening increased nearby house prices and that there were also positive "anticipation" effects, where nearby housing prices increased following the announcement of the new arena location and local government approval. 


\section{Acknowledgements}

I have many people to thank for supporting me throughout this journey. First, I would like to thank my advisor, Heather Stephens. I am extremely grateful for all of the guidance, mentorship, and opportunities that you have provided. Thank you for your patience during all of the learning curves and helping me shape my research identity. You truly went above and beyond the role of an advisor. Your willingness to lend a hand in any way that you could did not go unnoticed.

I would also like to thank the other members of my dissertation committee - Brad Humphreys, Peter Schaeffer, and Xiaoli Etienne. To Brad, thank you for all of your help and contributions in developing my research. I look forward to continuing to work together in the future. Also, thank you for helping me navigate the job market. Your advice provided clarity for many difficult decisions. To Peter, thank you for providing me with teaching opportunities. I learned so much from our experience teaching together. You are a big part of my development as an instructor and I plan to use the passion and skills that you shared with me to continue to grow as an educator. To Xiaoli, thank you for your constructive comments and feedback. Your insights are enlightening and extremely valuable for helping me conduct high quality research.

To all of my friends who have supported me during my time at WVU, thank you. Your friendship has made this journey incredible. Specifically, I would like to thank Alex, Fahad, Ritika, Shishir, Sam, Collin, Caleb, Elham, Mike O., Mike E., Lane, Jake, and Dan.

To my parents and brother, thank you for all of your love and encouragement. I would not be where I am today without you. Thank you always being there for me and providing me with the tools and support necessary to not only be a successful professional, but an even better person. I am fortune and blessed to have you as my family.

Lastly, I would like to thank my wife, Alanna. You have been with me every step of the way. There have been many early mornings, late nights, and stressful days in-between, and you never wavered. You have been my rock throughout this process and my daily reminder that together, we can accomplish anything. I love you and I am very blessed to have you in my life. 


\section{Table of Contents}

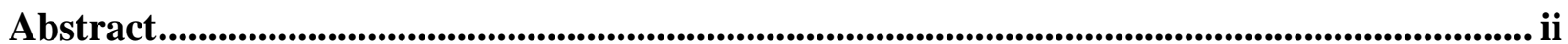

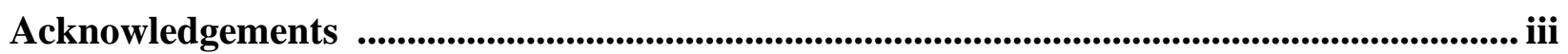

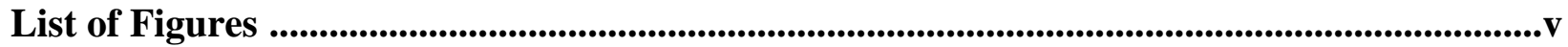

List of Tables ................................................................................................................................ vi

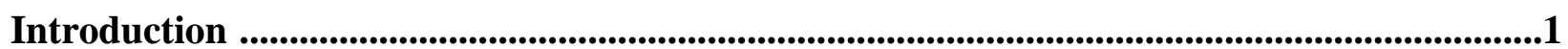

Chapter 1. Valuing Shale Gas Development in Resource Dependent Communities ................3

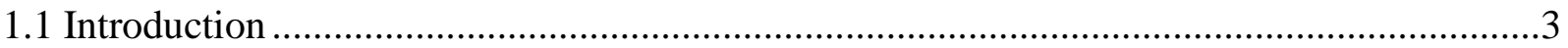

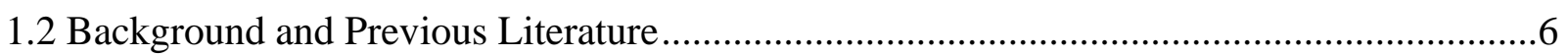

1.3 Conceptual Framework and Empirical Methodology ……..................................................12

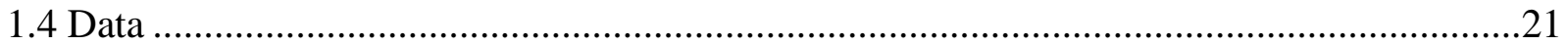

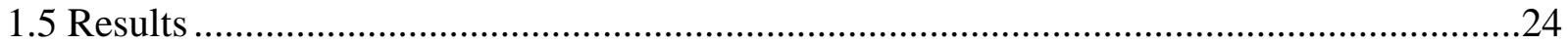

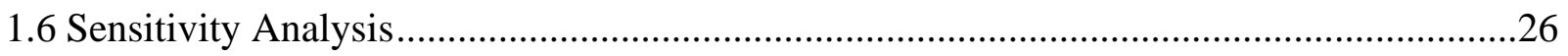

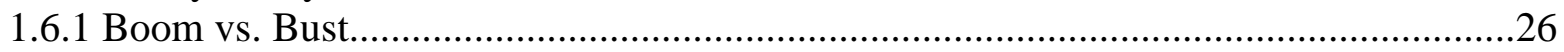

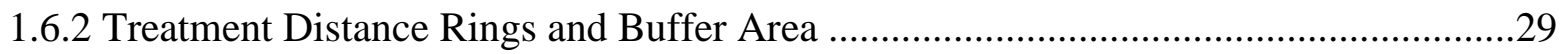

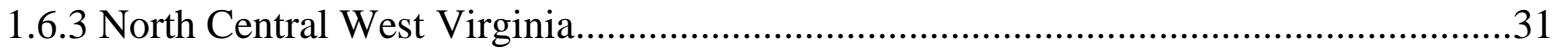

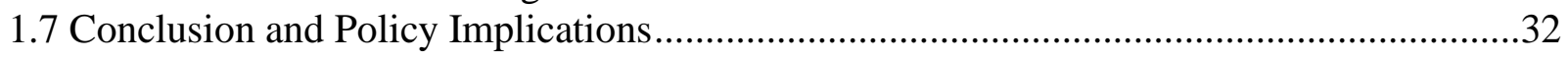

Chapter 2. The Capitalization of Metro Rail Access in Urban Housing Markets ..................36

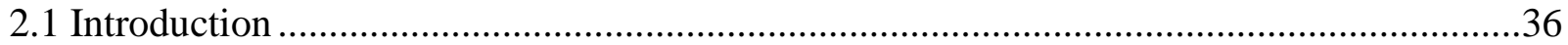

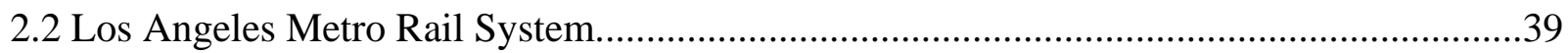

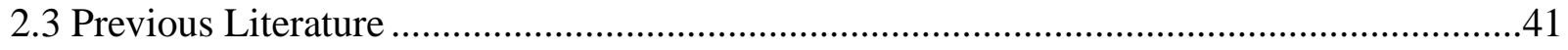

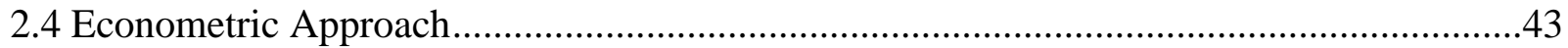

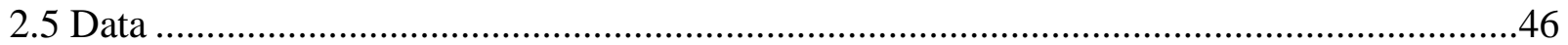

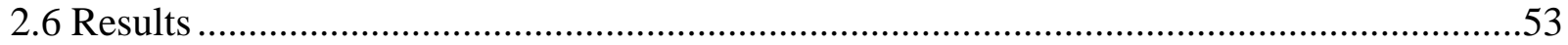

2.7 Sensitivity Analysis.....................................................................................................5

2.7.1 Robustness Check: Alternative Control Group ……....................................................57

2.7.2 Quantile Regression.............................................................................................6

2.7.3 Further Anticipation Analysis ..........................................................................62

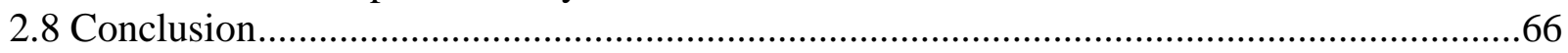

\section{Chapter 3. The Amenity Value of Sports Facilities: Evidence from the Staples Center in}

Los Angeles .................................................................................................................................................68

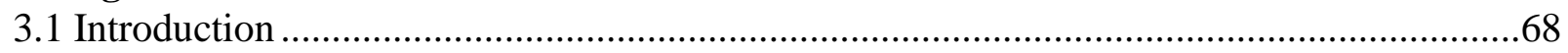

3.2 Existing Literature ..................................................................................................

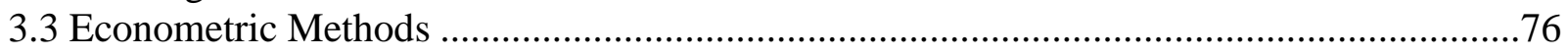

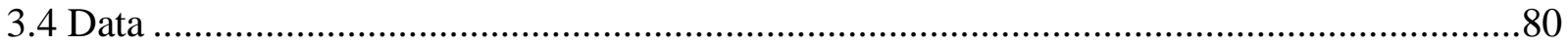

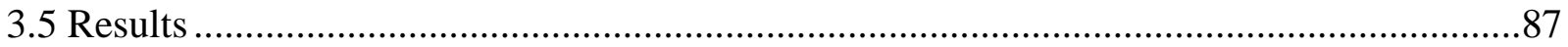

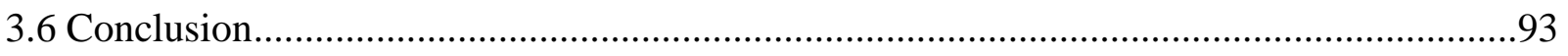

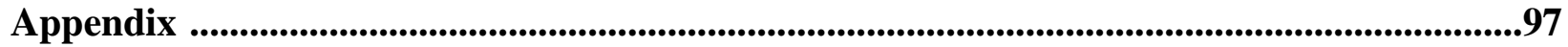

References ….............................................................................................................................105 


\section{List of Figures}

1.1. Shale Gas Production in West Virginia $(2005$ - 2015)................................................

1.2. Housing Transactions and Horizontal Wells in West Virginia $(2006-2015)$.....................23

2.1. Gold and Expo Stations Included in the Analysis ...................................................47

2.2. Parallel Trends Plot: Houses Near Gold Line Eastside Extension Stations ........................51

2.3. Parallel Trends Plot: Houses Near Expo Stations ............................................................52

3.1. Local Polynomial Regression (LPR) and Treatment Zone ..............................................79

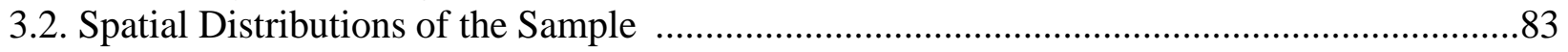

3.3. Parallel Trends Plot for Average House Transaction Prices $(1995$ - 2004) .......................87 


\section{List of Tables}

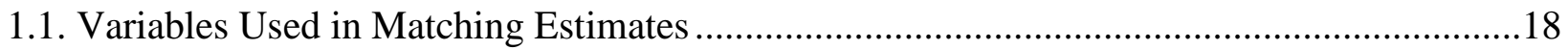

1.2. Means of Key Variables for Treated and Control Groups ..................................................20

1.3. CEM Results: Effect of Drilling Activity on Log Housing Prices in West Virginia (2006 -

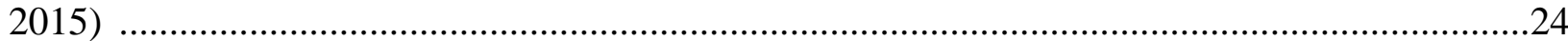

1.4. CEM Boom vs. Bust Results: Effect of Drilling Activity on Log Housing Prices in West

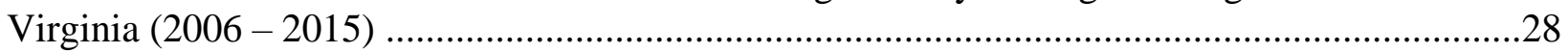
1.5. CEM Treatment Distance Rings Results: Effect of Drilling Activity on Log Housing Prices in West Virginia (2006 - 2015) …………………….....................................................

1.6. CEM Results: Effect of Drilling Activity on Log Housing Prices in North Central West

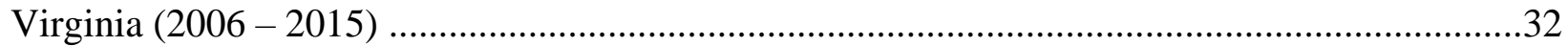

2.1. Means of Key Characteristics for Gold and Expo Station Areas (2010) ...............................40

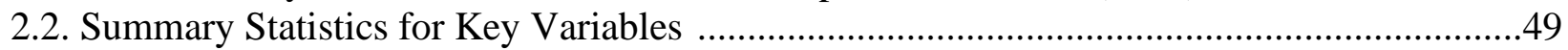

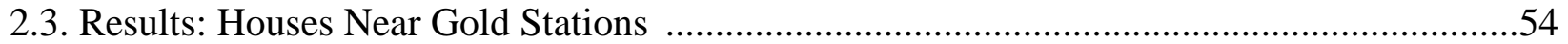

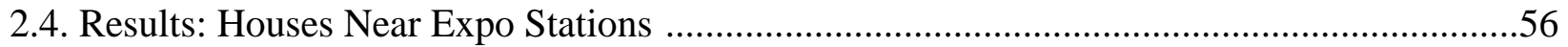

2.5. Alternative Control Group Results: Houses Near Gold Stations ...........................................58

2.6. Alternative Control Group Results: Houses Near Expo Stations ........................................59

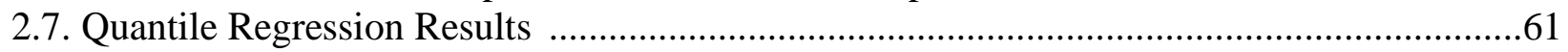

2.8. "Announcement” Results: Houses Near Gold Stations ........................................................63

2.9. “Announcement” Results: Houses Near Expo Stations ............................................................65

3.1. Means of Key Variables for Treated and Control Groups .....................................................8

3.2. Results: Effect of the Staples Center on Log Housing Prices in Los Angeles .......................89

3.3. Combined Models Results: Effect of the Staples Center on Log Housing Prices in Los

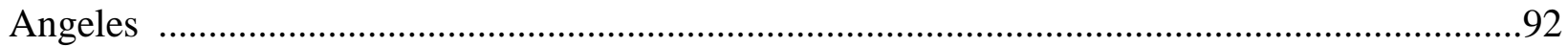

A1. Example House and Matching Strata ...............................................................................

A2. Hedonic Results: Effect of Drilling Activity on Log Housing Prices in West Virginia (2006 -

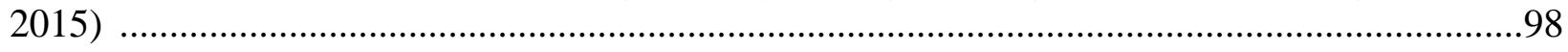

A3. CEM County and Year-of-Sale Interaction Results: Effect of Drilling Activity on Log Housing Prices in West Virginia (2006 - 2015) ...................................................................99 A4. CEM Census Tract Fixed Effect Results: Effect of Drilling Activity on Log Housing Prices in West Virginia (2006 - 2015) ……………………............................................................ 100 A5. CEM Two Year Lags Results: Effect of Drilling Activity on Log Housing Prices in West

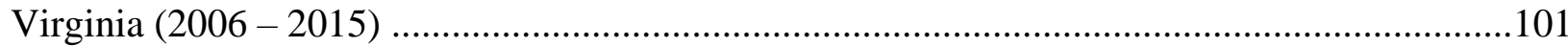
A6. Full Results: All Houses Combined (Both Gold and Expo Stations) ..................................102 A7. Full Results (Continuous Distance): All Houses Combined (Both Gold and Expo Stations)

A8. Full Results: Effect of the Staples Center on Log Housing Prices in Los Angeles 104 


\section{Introduction}

In this dissertation, I examine how proximity to an amenity or disamenity impacts house prices. One thing that is common in all of my essays is the use of hedonics. Hedonics is a common non-market valuation technique that has been used to estimate the value of various environmental amenities and disamenities. Hedonic valuation was introduced by Rosen (1974) and states that the price of a property is a function of its various attributes. For example, a bathroom of a house cannot be necessarily sold by itself. A house is a collection of attributes that each provides their own value to homeowners. In other words, the price of a house is a function of bedrooms, bathrooms, square feet, and other characteristics, including the surrounding environment and proximity to amenities and disamenities. In my research, I examine how proximity to shale gas development and urban development projects impact house prices, while controlling for other characteristics of the house. Through a hedonic model, I determine how proximity to the amenity/disamenity is capitalized into house prices and therefore give insight into the value that residents place on the amenity/disamenity.

In each chapter of my dissertation, I expand on the basic hedonic model. In Chapter 1, I use a matching technique and in Chapters 2 and 3, I use a hedonic difference-in-differences model as my main econometric approach. The matching approach that I use in Chapter 1 is Coarsened Exact Matching (CEM). I use this method to reduce the imbalance between the treated and control houses to obtain a reliable counterfactual. The main variable of interest in the hedonic difference-in-differences models that I use in Chapters 2 and 3 is an interaction term between those houses sold post-announcement/opening of the amenity/disamenity (Post) and those houses in close proximity (Treated). Or in other words, the impact of living in close proximity to an ameneity/disamenity after it was announced/opened. 
This research stems from spatial equilibrium theory, which predicts that if people can move across places, the value of amenities or disamenities will be capitalized into property values (Roback, 1982). Assuming that people choose their locations based on the interaction between supply conditions and preferences, then free migration creates a spatial equilibrium where welfare levels are equalized across space. Therefore, factors such as income and employment heterogeneity across space, as well as local amenities and disamenities, will affect migration and thus housing prices. New shale development and urban development projects have a number of competing forces, or benefits and costs, which could drive changes in house prices. For example, shale development can come with income and employment opportunities, but it is also associated with potential groundwater contamination. With urban development projects, residents have the benefit of increased access to the amenities, but they are also associated with negative externalities such as noise and crime. Therefore, differences in house prices will be reflective of the net valuation that residents have for the benefits as well as the costs. If the benefits outweigh the costs, then house prices should increase. And, we would expect house prices to decrease if the negative externalities outweigh the benefits.

The rest of this dissertation is structured to discuss each essay in detail. 


\section{Chapter 1}

\section{Valuing Shale Gas Development in Resource-Dependent Communities}

\subsection{Introduction}

Innovations in oil and gas drilling technologies have substantially altered energy perspectives throughout the United States. The expansion of unconventional drilling methods such as hydraulic fracturing and horizontal drilling have made the extraction of natural gas from shale (shale gas $^{1}$ ) and shale oil economically viable. These innovations have led to a great deal of investment in several regions, including the Marcellus and Utica regions, which underlies West Virginia and several surrounding states. ${ }^{2}$ Shale gas is now a major contributor to U.S. natural gas production; while Marcellus Shale accounts for a majority of this production (Rahm et al., $2013)^{3}$

In this paper, we examine how the benefits and costs of shale development are capitalized into housing prices in West Virginia, a state with a long history of resource extraction, which may result in residents valuing shale gas development differently than in other regions. For example, residents in West Virginia may be optimistic about the potential income and employment opportunities based on their prior history with extraction-based industries (Betz et al., 2015), especially since the areas prone to drilling are generally rural and economicallylagging places where residents could benefit greatly from more economic activity. At the same

\footnotetext{
${ }^{1}$ Shale gas is natural gas and liquids found in shale formations that date back hundreds of million years (DOE, 2013).

2 It is estimated that the Marcellus Shale contains over 84 trillion cubic feet of untapped natural gas reservoirs (USGS, 2018). The other states are Ohio, Pennsylvania and New York. However, while New York also contains the Marcellus Shale Formation, it has a moratorium on drilling (Kargbo et al., 2010).

${ }^{3}$ Shale gas accounted for 1.6 percent of U.S. natural gas supply in 2000, a figure that rose to 23.1 percent by 2010 (Wang and Krupnick, 2013).
} 
time, extraction-based industries are subject to booms and busts. A study by Douglas and Walker (2016) measures the effects of resource-sector dependence on long-run income growth in 409 Appalachian counties. They find that a "one standard deviation increase in resource dependence is associated with $0.5-1$ percentage point long-run and a 0.2 percentage point short-run decline in the annual growth rate of per capita personal income" (Douglas and Walker, 2016: 568). Thus, it may be the case that residents with experience of resource extraction are even more aware of the negative externalities and the potential for the busts associated with this type of activity. At the same time, the presence of resource extraction may also deter people from locating in those areas. For these reasons, the capitalization effect of drilling in resource-dependent communities may differ from that in areas where residents are less familiar with resource extraction and/or where there are other economic development opportunities.

Previous research on the capitalization of drilling into housing values in the Marcellus region has mostly focused on Pennsylvania (i.e. Gopalakrishnan and Klaiber, 2013; Muehlenbachs et al., 2015; Delgado et al., 2016). However, these results may not reflect how drilling may be valued in West Virginia given its history with resource extraction and economic distress. Other national studies related to the employment and income effects from shale development have included West Virginia (such as Feyrer et al., 2017), however, the results of these studies are averages across the nation, and again may not reflect the impacts on regions with a history of resource extraction and economic distress.

We also contribute to the literature by considering the impact of shale development over both boom and bust cycles. Other similar studies that consider the capitalization effect of drilling only do so during the initial ramp-up period of the shale boom that begin in earnest in 2009. For example, Muehlenbachs et al. (2015) only includes observations through 2012. While 
unconventional drilling was becoming popular during this time period, residents may not have experienced the negative externalities. Also, given the boom and bust nature of resource extraction (Akbar et al., 2013), residents purchasing a house during this timeframe may have been willing to pay more to live near drilling activity because they had not yet experienced the economic post-boom downturn or slowdown. We examine the impact through 2015, as drilling begins to taper off, thus we are able to assess the capitalization effect when residents experience both the boom and the bust.

In addition to examining the impact of shale development on a resource-dependent region and over both the boom and bust cycles, our research makes an important methodological contribution to the overall non-market valuation literature by using a methodology that addresses the challenges of sparse housing markets with a relatively small number of housing transactions. Since the West Virginia housing market has a relatively small number of housing transactions, traditional hedonic methods for valuing the effects from shale development (Rosen, 1974) may not be appropriate. For example, in a community where only a few houses sell in a year, other nearby houses that sell may not be comparable. To address this, we use coarsened exact matching $(\mathrm{CEM})$, to impute counterfactual observations by pairing treated homes with similar homes from a control group. CEM, which is described in detail by Iacus et al. $(2011 ; 2012)$ and Blackwell et al. (2009), is an underutilized technique that temporarily coarsens the data and matches on strata comprised of similar covariates from the treated and control groups. CEM ensures that each characteristic of matched houses will be substantively similar, rather than houses being matched that may have very different characteristics. When there are few transactions, other methods may match houses that are similar in some ways, but completely 
different in others and thus may not necessarily be comparable. Once houses are matched, we are more accurately able to estimate the average effect of being located near drilling activity.

Our results suggest that even in places with few other economic prospects, residents more familiar with local resource extraction negatively value shale gas development near their homes, or at least do not perceive it positively. We also find some evidence that the price of all houses (regardless of water source) decreases as the number of surrounding wells increases. This is in contrast to the results from Muehlenbachs et al. (2015) who find a positive impact for houses with a public water source. However, we do find some evidence of a positive capitalization effect during the initial ramp up period when drilling was increasing and for houses located in drilling communities but not directly next to wells (which is consistent with the previous studies). At the same time, as drilling has tapered off (in the later time period), the decrease in prices near wells suggests that people who live close to wells are no longer benefiting from increases in jobs and income, but are only experiencing the negative externalities.

In what follows, we further motivate the research and review the previous literature. We then discuss our method, our data, and our results. Finally, we conclude and discuss the implications for policy.

\subsection{Background and Previous Literature}

West Virginia has a long history of resource extraction, beginning with timber in the early $20^{\text {th }}$ Century, continuing with coal mining, and now natural gas. Coal has been especially important to the state's economy for more than a century, with West Virginia long having been the second-largest coal producer in the nation (EIA-B, 2018). In 2016, West Virginia provided approximately $4.5 \%$ of the nation's total energy, a majority from coal and natural gas (EIA-B, 
2018). As shown in Figure 1.1, given its location overlying the Marcellus and Utica Shale formations, since the beginning of the shale boom around 2010, West Virginia saw shale gas production in the state increase dramatically. In 2016, 1,375,108 million cubic feet of natural gas were extracted from West Virginia, with shale gas accounting for almost $90 \%$ of the state's total production (EIA-A, 2017; EIA-B, 2018). In 2016, West Virginia was the seventh-largest natural gas producing state in the nation with shale gas reserves exceeding 23 trillion cubic feet (EIA-B, 2018).

Figure 1.1. Shale Gas Production in West Virginia (2005 - 2015)

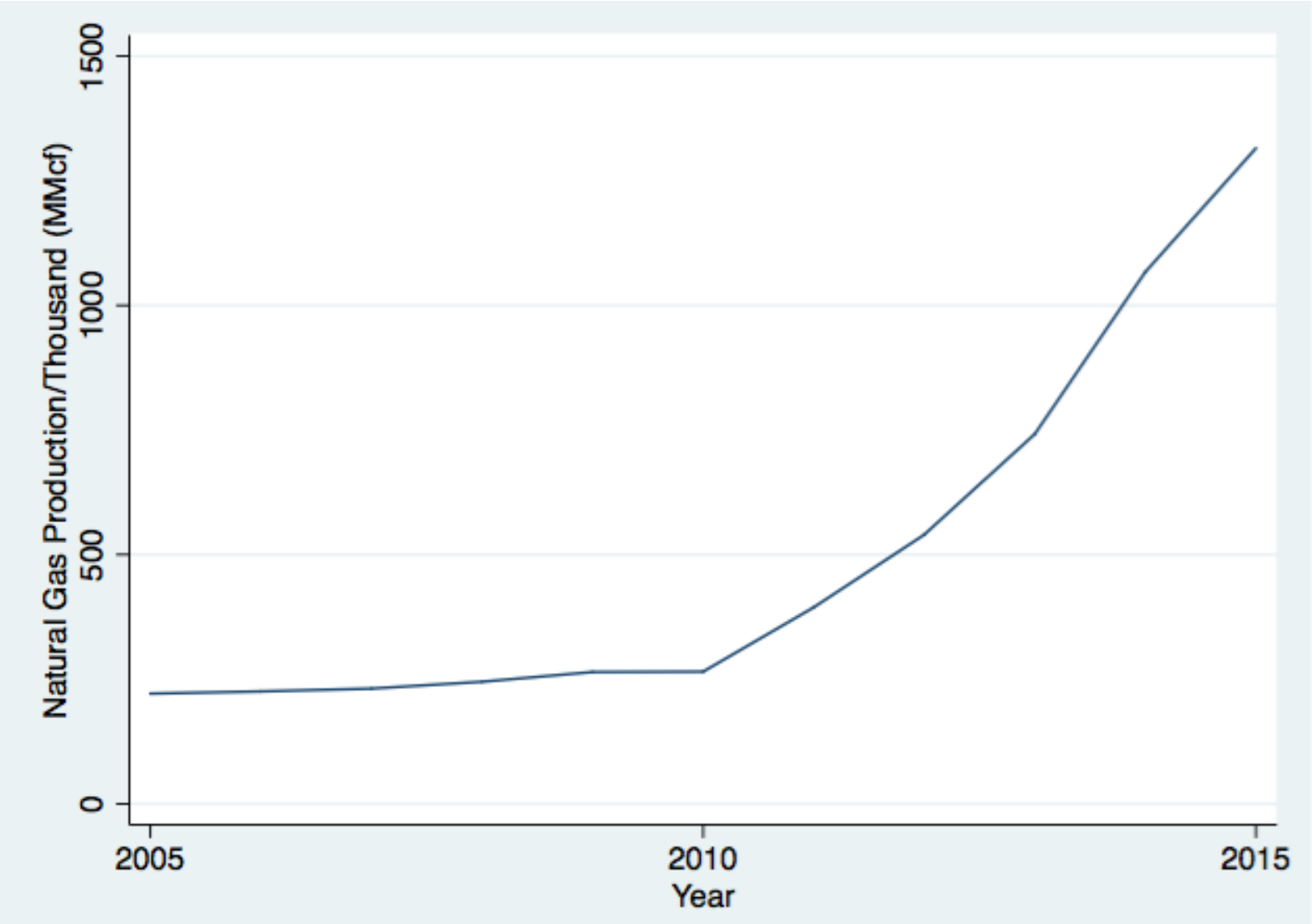

Notes: The figure shows shale gas production in West Virginia from 2005 to 2015 (EIA-A, 2017).

Despite the wealth of natural resources, West Virginia has generally not benefited economically from resource extraction. As the resources (from timber to coal to natural gas) 
have left the state, the companies with corporate headquarters elsewhere have profited, but West Virginia has lagged economically. West Virginia is the only state entirely within the U.S. federally-designated Appalachian Regional Commission (ARC) region, which was designated in the 1960s due to its persistent poverty and economic distress (Stephens and Partridge, 2011). Today, despite some gains, labor force participation in the state continues to be chronically low (Stephens and Deskins, 2018) and most counties in the state have lower levels of education, higher unemployment, and poverty rates below the national average. For example, the average unemployment rate in West Virginia in 2017 was 5.2\%, which was considerably higher than national average of $4.4 \%$ (BLS, 2018). Given its economic distress, shale gas development may be a welcomed addition to the region given the benefits from employment and income opportunities. Hajkowicz et al. (2011) find that resource extraction has positive effects on incomes, housing affordability, communication access, education, and employment in rural regions of Australia whose economies are very resource-dependent. However, drilling activity can also "transform a previously pristine and quiet natural region, bringing increased industrialization" and the associated unwanted negative externalities (Barth, 2013: 92). Additionally, Haggerty et al. (2014) find that long-term oil and gas specialization can have negative effects on change in the per capita income, crime rate, and education rate. Thus, West Virginias may recognize this given their history with resource extraction.

Increased shale gas development activity and other resource extraction may benefit local areas through increases in employment and income, business activity, government revenues, and public financing (Brown, 2014; Fetzer, 2014; Feyrer et al., 2017; Gerton et al., 2017; Hartley et al., 2015; Marcos-Martinez et al., 2019; Munasib and Rickman, 2015; Paredes et al., 2015; Tsvetkova and Partridge, 2016; Weber, 2012; Weber et al., 2016; Weinstein, 2014; Weinstein 
and Partridge, 2011). For example, employment in oil and gas extraction in West Virginia in 2016 exceeded 15,000 jobs, more than double the number of jobs in 2006 (BEA, 2018).

However, there is some evidence that many of these jobs may go to individuals outside the area. For example, Kelsey et al. (2011) find that 37\% of Pennsylvania oil and gas jobs went to nonresidents. Additionally, Weinstein et al. (2018) find that oil and gas earnings multipliers are modest and the widespread use of in-migrant workers presents evidence of leakages and positive spillovers from nearby counties. This suggests that "energy workers may prefer to live in metro counties and commute to nonmetro counties where the extraction mostly takes place" (Weinstein et al., 2018: 205). Thus, it will be important to consider the impacts of commuting.

Another way that residents may benefit is from lease and royalty payments. Prior to drilling, owners of sub-surface mineral rights may sign a mineral lease contract that grants energy production companies the right to drill on their property. A number of previous researchers have considered the size of these benefits (Brown et al., 2016, Fitzgerald and Rucker, 2016; Harleman and Weber, 2017). Brown et al. (2016) estimates that the six major shale plays in the U.S. generated $\$ 39$ billion in royalties in 2014. The payments vary based on acreage and amount of production, and although there is uncertainty regarding the size and regularity of payments, the potential income opportunity could be quite substantial for nearby residents and will affect nearby housing prices. However, in many cases, the ownership of mineral rights is different than the ownership of surface rights ("split estate"), thus homeowners may or may not benefit from royalty payments from nearby shale gas extraction. And, these homeowners still have to deal with the potential negative impacts of drilling on their property. In a survey of landowners, Collins and Nkansah (2015: 688) find that "split estate owners had a statistically greater number of reported problems with drilling." 
Although residents may recognize the benefits from shale gas development, the inevitable "bust" usually follows the "boom" (Esposito and Wimmer, 2003). Shale gas wells are typically assumed to have a minimum life of thirty years, but most of the production occurs in the initial years (Hughes, 2014). At the same time, most resource extraction is subject to wide variation in production. Economic decline due to lack of investments in resource-rich areas known as the Resource Curse (Papyrakis, 2017) may even lead resource-dependent regions to be worse off after a boom. And, residents in West Virginia who have experienced previous resource booms (and busts) may realize this. While Weber (2014) finds little evidence of an emerging resource curse from natural gas production in the south-central United States, that study ends in 2010 and does not consider West Virginia or anywhere in the Marcellus Region. And, West Virginia's previous experience with resource extraction has not benefited the state's economy long term.

Beyond the economic effects, shale development is also associated with negative externalities and other negative spillovers, including increased traffic, road damage, noise pollution, crime (Lim, 2018; Komarek, 2018), reductions in high school and college attainment (Rickman et al., 2017), and negative effects on well-being (Maguire and Winters, 2017). There are also environmental concerns including air pollution (Litovitz et al., 2013; Rich et al., 2014; Mckenzie et al., 2012), forest fragmentation (Drohan et al., 2012), seismicity (Ferreira et al., 2018; Frohlich, 2012), and water contamination (Abdalla et al., 2012). Jackson et al. (2013) find evidence of increased levels of methane contamination in groundwater from shale development, while Olmstead et al. (2013) find contamination in surface water from waste disposal and management processes. At the same time, natural gas extraction has led to an increase in wastewater management needs (Rahm et al., 2013) and regional wastewater generation (Lutz et al., 2013). In addition to the negative social and environmental externalities, shale wells may be 
aesthetically unappealing and may drive individuals to live away from these sites, driving down housing values in proximity of drilling. If groundwater contamination is an issue, residents in rural areas who are reliant on groundwater (well water) are the most at risk of losing a reliable water source which may further drive down housing values.

Much of the prior research in the Marcellus Shale region has focused on Pennsylvania and on the early years of the shale boom. For example, Gopalakrishnan and Klaiber (2013) utilize a hedonic framework to examine the impact of shale development on house prices in the relatively urbanized areas near Pittsburgh, Pennsylvania, including Washington County, in the first few years of the shale gas boom. Analyzing the intensity and proximity to shale activity, they find that nearby shale gas development activity has a small negative impact on all house prices, but houses close to major highways and sourced with private (well) water are affected more. In a study of a similar area, Muehlenbachs et al. (2013) show there is a larger negative effect, but only for houses sourced with private water. In follow up work, Muehlenbachs et al. (2015) use a more comprehensive dataset of 36 Pennsylvania counties and matching techniques using housing transactions through 2012 - when drilling was still booming. Their results indicate that shale gas development activity decreases prices of houses that are groundwater dependent (prices decrease by 9.9. to 16.6 percent) but that prices for houses on public water are slightly increased. Other related research, such as that by Delgado et al. (2016) finds weak evidence that shale gas development decreases house prices in the north central counties of Lycoming and Bradford, Pennsylvania. Additionally, a study that uses properties in Pennsylvania as counterfactuals finds that the moratorium on drilling activity in New York decreased property values for those homes with a private water source, suggesting that there is a positive net valuation from shale gas development (Boslett et al., 2016). However, Boslett and Hill (2019) 
find that the announcement of a proposed pipeline to transport hydraulically-fractured natural gas decreased property values in New York.

Several other studies have also looked at the impact of new drilling activity on property values in other regions. For example, findings from a study in Alberta, Canada, suggest that property values are negatively correlated with the number of sour gas wells (Boxall et al., 2005) ${ }^{4}$ and from a study in Tarrant County, Texas, it appears that properties in closer proximity to hydraulically fractured natural gas wells sell for less (Balthrop and Hawley, 2017). Finally, multiple studies in Colorado (Boslett et al., 2019; James and James, 2014; and Stephens and Weinstein, 2019) find that drilling activity has a negative impact on housing values regardless of water source.

The disparities in findings between these studies suggest there is heterogeneity in how residents can value shale gas development.

\subsection{Conceptual Framework and Empirical Methodology}

The spatial equilibrium economic theory predicts that if people can move across places, the value of amenities (or disamenities) will be capitalized into property values (Roback, 1982). Assuming that people choose their locations based on the interaction between supply conditions and preferences, then free migration creates a spatial equilibrium where welfare levels are equalized across space (Glaeser and Gottlieb, 2009). Therefore, factors such as income and employment heterogeneity across space, as well as local amenities and disamenities, will affect migration and thus housing prices.

\footnotetext{
${ }^{4}$ While not a study of shale gas, sour gas is a natural gas containing large amounts of acidic gases such as hydrogen sulfide and carbon dioxide that can be considered an environmental hazard.
} 
New shale development has a number of competing forces that could drive changes in house prices and reveal the value that residents place on nearby drilling. New shale development activity can create income and employment opportunities for local residents and drive up housing prices. However, higher wages and job opportunities in drilling communities do not imply that those residents are better off. Instead, higher incomes may go to outsiders or may be offset by the negative externalities associated with shale development activity, especially for houses closest to the wells.

Therefore, differences in house prices will be reflective of the net valuation that residents have for the benefits as well as the costs of shale development activity in the area. If residents who live close to shale gas wells value the income and employment opportunities more than the negative externalities, then houses in closer proximity to drilling should sell for more. Alternatively, house prices may decrease if the costs outweigh the benefits. The net capitalization effect (i.e. higher or lower prices) will reflect these tradeoffs. Thus, our study attempts to quantify the capitalization effect of new shale drilling activity on housing values.

Introduced by Rosen (1974), hedonic models have become a common tool for economists to determine how an amenity or disamenity is capitalized into house prices (i.e. Clark et al., 1997; Cohen and Coughlin, 2009; Heintzelman and Tuttle, 2012). Such indirect valuation methods allow us to infer the value of housing characteristics from market transactions (Taylor, 2003). In other words, house prices are reflective of the attributes of the house (i.e. bedrooms, bathrooms, square footage, etc.) as well as the attributes of their surrounding location (i.e. amenities and disamenities). 
Following the guidance in the previous literature (e.g., Black, 1999; Palmquist, 2005; Kuminoff et al., 2010) to address omitted factors and minimize omitted variable bias, a hedonic model for this setting is shown in Equation (1).

$$
\log (\text { Price })_{i j t}=\beta_{0}+\beta_{1} X_{i j t}+\beta_{2} D_{i j t-1}+\beta_{3} N_{i j t}+\theta_{j}+\eta_{t}+w+\varepsilon_{i j t}
$$

$\log (\text { Price })_{i j t}$ is the natural $\log$ of the price of house $i$ in county $j$ in time $t$, which minimizes the impact of outliers and allows changes in characteristics to have percentage or relative effects on housing prices. $X_{i j t}$ is a set of house characteristics (number of bedrooms, number of bathrooms, building square feet, acres of land, age, groundwater dependency, distance to the closest MSA, distance to the closest major city, and distance to the closest interstate). $D_{i j t-1}$ measures drilling activity, or the number of producing wells in the previous year within certain distances. ${ }^{5}$ Other community characteristics are included in $N_{i j t}$. For all models, $N_{i j t}$ includes one-year lagged mining employment in the county where the house was sold to account for the changes in mining employment that also take effect in these areas during this time period. In some model specifications, $N_{i j t}$ also includes tract-level characteristics, including population density and the average number of bedrooms, bathrooms, square feet, acres, and age for all single-family houses in the tract in which the house is located. We also include a county fixed effect, $\theta_{j}$, a year-of-sale fixed effect, $\eta_{t}$, and a commuting zone fixed effect, $w .{ }^{6}$ County fixed effects should help control for any time-invariant spatial components, including school quality, as the previous literature (Black, 1999) has shown that residents pay a premium to live in better

\footnotetext{
${ }^{5}$ Unfortunately, we do not have access to the production data for each well. Therefore, we are unable to include this in our analysis.

${ }^{6}$ After exact matching on commuting zone, the commuting zone fixed effect drops out in the models using matching.
} 
school districts and school districts in West Virginia follow county boundaries. Year-of-sale (time) fixed effects should control for changes in overall market conditions. We also interact $D_{i t}$ and groundwater dependency in some models to see if places on well water are more affected by drilling activity (as has been found in the previous literature).

Hedonic estimation, however, should be used cautiously in places with few transactions, such as in West Virginia. The assumptions of the hedonic pricing model may not be valid in these areas. For example, in a community where only a few houses sell in a year, other nearby houses that sell may not be comparable. Thus, the non-treated houses (those farther away from drilling) may not be a good control group for measuring the effect of drilling on housing values because they may be very different in a number of ways. Especially with a small number of transactions, there are additional concerns with hedonics, related to role of uncertainty and risk aversion (Mense, 2017), and misspecified spatial effects (McMillen and Redfearn, 2010).

To address the challenges of hedonics in this setting, we use an underutilized matching method, CEM, to reduce the imbalance in covariates between treated and control groups and obtain a more reliable counterfactual (Iacus et al., 2011; Iacus et al., 2012; Blackwell et al., 2009; Patrick and Mothorpe, 2017). ${ }^{7}$ It is a type of data pre-processing that has certain advantages over other techniques, such as entropy balancing (Hainmueller, 2012) and propensity score matching (King and Nielsen, 2019). For example, while entropy balancing requires the means of the covariates to be equal, CEM only requires that the covariates for the matches for each treated observation are similar. This helps ensure that we have good counterfactuals to our treated houses while also retaining an adequate number of matches in a market with a small number of transactions. Additionally, propensity score matching only matches on a predicted probability of

\footnotetext{
${ }^{7}$ Coarsened Exact Matching is implemented using the 'cem' command in STATA.
} 
treatment, not on individual housing characteristics, and thus, as shown in King and Nielsen

(2019), can actually increase imbalance, inefficiency, model dependence, and bias.

Before any matching begins, the comparison group is comprised of all non-treated

observations included in the dataset. CEM then temporarily places each characteristic (or potential matching variable) into strata based on similar values based on natural breaks in the distribution of the variables. For example, in our specification of CEM, a treated house with three bedrooms and three bathrooms will only be matched to non-treated houses that have three to four bedrooms and three to four bathrooms. Houses are then matched on all characteristics simultaneously. For houses to match, they must be in the same strata for every variable included in the matching algorithm. ${ }^{8}$ This ensures that every characteristic will be substantively similar for the houses that are matched, rather than houses being matched that may have very different characteristics.

In our main analysis, a house is considered to be treated if there is a producing well within four miles. ${ }^{9}$ However, since houses that are only slightly more than four miles away may be across the street from our "treated" houses, we only consider houses more than five miles from a producing well as controls. ${ }^{10}$ In other words, potential control houses have no producing well within a five-mile area of the house. This one-mile buffer allows for a distinct difference in

\footnotetext{
${ }^{8}$ For additional details on how houses are matched using the CEM approach, see Appendix A1.

${ }^{9}$ We considered a house to be treated if there is a well within 4 miles because only a small number of houses had wells in closer proximity. For example, there were only 116 houses that had a well within 1 mile before matching. This figure jumps to 2,570 when using a treatment distance of 4 miles, which represents a 47 percent change increase from a treatment distance of 3 miles. Therefore, 4 miles may be the most appropriate treatment distance because it is the closest distance we can use while still having an ample number of transactions for our estimation. However, we also estimate models (not shown) with treatments of 2 and 3 miles and the results are similar, though less robust due to the small number of treated houses.

${ }^{10}$ For example, if a house 4 miles away from a well is considered treated and a house in the same neighborhood that is 4.01 miles away is considered a control, we may not be isolating the effect because the houses are in close proximity to each other. A one-mile buffer ensures a distinct difference between treated and control houses. Additionally, we only lose a very small portion of observations before matching, so we do not believe there is any sample selection issue. However, we also use a larger buffer of 2 miles (not shown) and the results are similar.
} 
the effect of drilling activity between the treated and control groups. Our goal is to find the difference between the price of a treated house, an observable quantity, and the counterfactual price of that house had the house not been affected by drilling. The problem is that the price of a treated house when it is not treated (or if farther away from a well) is not observed. Simply comparing the differences in the price of a treated house to a random untreated house will likely produce biased estimates, especially in a rural region with few house sales. Thus, we use CEM to get a control group of untreated homes that are similar to our treated homes (those near drilling).

As with any matching approach, the variables used for matching will determine which houses will be considered matches. To control for confounding variables that affect both the treatment and price of a house, we match on a variety of covariates and try several matching specifications to ensure our results are not sensitive to our matching specification. Each specification matches on the attributes of the house: the number of bedrooms, number of bathrooms, square feet, acres, and age. We also exactly match on commuting zone, since previous research has found that shale-related jobs may go to people outside the area and some residents may live outside of the county where they are employed. This also ensures that each house will be in the same labor market. In Specification 1, we also match on the neighborhood (census tract) characteristics. We match on these neighborhood characteristics to achieve a better counterfactual because these averages are representative of the surrounding houses and may confound the treatment and price of the house. ${ }^{11}$ While this specification may be preferred, we lose over half of our treated sample after matching. Thus, in Specification 2 we only match on housing attributes and commuting zone in order to retain more of the treated houses.

\footnotetext{
${ }^{11}$ For example, a large house near small houses would most likely sell for less than the same house surrounded by other large houses.
} 
After matching, we estimate Equation (1) using our treated and matched samples. In addition to controlling for the matched houses, we also include the house-specific variables we matched on in our regressions to minimize measurement error. To account for the tract-level characteristics that are not used in matching in Specification 2, we control for them in the model. The covariates we match on are included in Table 1.1. Figure 1.2 shows the treated and control houses included in our analysis from Specification 2.

\section{Table 1.1. Variables Used in Matching Estimates}

\begin{tabular}{ll}
\hline \multicolumn{1}{c}{ Specification 1 } & \multicolumn{1}{c}{ Specification 2 } \\
House Specific Variables & House Specific Variables \\
Bedrooms & Bedrooms \\
Bathrooms & Bathrooms \\
Square Feet & Square Feet \\
Acres & Acres \\
Age & Age \\
Neighborhood Characteristics (Tract-Level) & Spatial Control \\
Population Density & Commuting Zone (Exact match) \\
Average Price & \\
Average Bedrooms & \\
Average Bathrooms & \\
Average Square Feet & \\
Average Acres & \\
Average Age & \\
Spatial Control & \\
Commuting Zone (Exact match) & \\
Notes: The table presents the variables used in the matching algorithm for each specification.
\end{tabular}

As previously mentioned, the West Virginia housing market has a fairly limited number of transactions (as does the market in many rural areas) and there may be systematic differences between houses located near drilling activity and those that are not. As shown in Table 1.2, treated houses before using matching are much different from the control homes. Thus, hedonic 
estimation without matching may not be appropriate because there may be factors that affect the assignment of treatment, as well as the outcome, that bias the estimates. After matching, Table 1.2 shows that our treated and untreated homes appear to be similar, suggesting that the matches provide a reliable counterfactual to help isolate the effect of being located near drilling activity. 
Table 1.2. Means of Key Variables for Treated and Control Groups

\begin{tabular}{|c|c|c|c|c|c|c|c|c|c|}
\hline & \multicolumn{3}{|c|}{ Sample Before Matching } & \multicolumn{3}{|c|}{ Specification 1} & \multicolumn{3}{|c|}{ Specification 2} \\
\hline & $\begin{array}{c}\text { Treated } \\
(\mathrm{n}=2,570)\end{array}$ & $\begin{array}{c}\text { Control } \\
(\mathrm{n}=12,595)\end{array}$ & $\operatorname{Pr}(|\mathrm{T}|>|\mathrm{t}|)$ & $\begin{array}{l}\text { Treated } \\
(\mathrm{n}=721)\end{array}$ & $\begin{array}{l}\text { Control } \\
(\mathrm{n}=657)\end{array}$ & $\operatorname{Pr}(|\mathrm{T}|>|\mathrm{t}|)$ & $\begin{array}{c}\text { Treated } \\
(\mathrm{n}=2,178)\end{array}$ & $\begin{array}{c}\text { Control } \\
(\mathrm{n}=4,246)\end{array}$ & $\operatorname{Pr}(|\mathrm{T}|>|\mathrm{t}|)$ \\
\hline House Price & $149,218.20$ & $139,920.20$ & 0.0001 & $147,765.00$ & $159,713.70$ & 0.0191 & $147,361.90$ & $153,468.40$ & 0.0253 \\
\hline Bedrooms & 2.88 & 2.96 & 0.0000 & 2.78 & 2.80 & 0.4936 & 2.83 & 2.86 & 0.1382 \\
\hline Bathrooms & 1.91 & 1.97 & 0.0026 & 1.81 & 1.88 & 0.1286 & 1.86 & 1.91 & 0.0177 \\
\hline Square Feet & $1,608.00$ & $1,705.22$ & 0.0000 & $1,481.41$ & $1,510.89$ & 0.3329 & $1,559.13$ & $1,595.49$ & 0.0313 \\
\hline Acres & 0.85 & 0.84 & 0.8560 & 0.32 & 0.39 & 0.0783 & 0.47 & 0.47 & 0.9972 \\
\hline $\begin{array}{c}\text { Age } \\
\text { No. Wells }\end{array}$ & 57.37 & 51.13 & 0.0000 & 53.26 & 48.26 & 0.0065 & 57.04 & 46.66 & 0.0000 \\
\hline Within 4 mi. & 6.90 & 0 & 0.0000 & 3.31 & 0 & 0.0000 & 7.06 & 0 & 0.0000 \\
\hline
\end{tabular}

Notes: The table presents the means of the treated (houses with a well within 4 miles) and control (houses more than five miles from a well) groups for the sample before matching and both specifications. Also included is the p-value for a t-test for difference in means between the treated and control groups for each sample. 
We recognize that our empirical approach may not solve all endogeneity issues. For example, our county fixed effects may not capture enough of the local variation in unobservables. Thus, after our initial analysis, we test the robustness of our results. First, we estimate models in which we interact the county and year-of-sale fixed effects to control for local factors that may change over time. We also try using smaller geographic fixed effects by using census tract fixed effects. We also estimate models where we measure the presence of producing wells two years previously.

We conduct further robustness checks by varying the treatment - considering a house to be treated if a well is within treatment rings of 0 to 4 miles and 4 to 8 miles, with a buffer of 2 miles such that untreated houses are 10 or more miles away from a well. We also consider different buffers around our treated houses as nearby (but untreated) houses may see the benefits but not the costs. Because after 2011, the boom started to fade out, we also split our sample by boom and bust periods to see if there is a difference. ${ }^{12}$ Finally, we limit our analysis to a single labor market. Additional details on these analyses are provided below. ${ }^{13}$

\subsection{Data}

For our analysis, we use West Virginia housing data from 2006 to 2015 purchased from Corelogic. ${ }^{14}$ The data include traditional housing characteristics such as bedrooms, bathrooms, square feet, acres, year built, and year sold. Also included are the location (latitude and

\footnotetext{
${ }^{12}$ Ideally, we could have explored the effect by year, however, given the small number of transactions we did not have sufficient data to do so.

${ }^{13}$ We also explored a possible falsification test, though we were unfortunately unable to conduct such analysis in this setting.

${ }^{14}$ The housing data used in our analysis were purchased under a license from Corelogic through their university data portal, https://www.corelogic.com/solutions/university-data-portal.aspx.
} 
longitude) and sale price of the house. ${ }^{15}$ In order to adjust for inflationary and deflationary periods, housing prices are normalized in 2015 dollars. To ensure market transactions, we only include single-family houses that were considered an arms-length transaction. ${ }^{16} \mathrm{We}$ also remove observations with missing or zero values for our key variables, as well as observations with outliers. We use approximately the $1^{\text {st }}$ and $99^{\text {th }}$ percentiles as the limits of the bounds for each characteristic of those transactions we retain, as suggested by Klaiber (2008). We also remove observations from areas of the state that are not in the same labor markets as the drilling activity. Our final dataset before matching includes 15,165 transactions.

Data on shale gas wells were accessed from Drillinginfo.com and include the latitude, longitude, and active dates of the wells. ${ }^{17}$ For the purpose of this study, we only use data for horizontal producing wells. This allows us to isolate the effect of unconventional drilling methods, especially since these methods are the major contributor of the growth of natural gas development in this region.

Using ArcGIS and STATA software, we were able to determine the proximity of horizontal producing wells to houses. Since housing markets may need time to adjust to changes in the physical environment (Case and Shiller, 1989; Wheaton, 1990; McMillen and McDonald, 2004) and to avoid simultaneity, we consider a well to be active if it was producing the year prior to the sale of the house (however, we also remove observations where drilling began in the year

\footnotetext{
${ }^{15}$ Information on whether or not the owner of the house had mineral rights or was receiving royalty and lease payments is not included in our data. Therefore, we are unable to examine the effect of these potential income sources on house prices.

${ }^{16}$ An arms-length transaction is one in which a buyer and seller act independently and in their own self-interest. This allows for a more homogenous sample of houses in which buyers and sellers are motivated to sell at a market price.

17 The drilling data used in our analysis were obtained under a license through the university outreach program at Drillinginfo.com.
} 
of the sale to avoid confounding our results). ${ }^{18} \mathrm{We}$ were also able to determine proximities of houses to the center of the closest metropolitan statistical area (MSA) such as Morgantown, WV, major city ${ }^{19}$, and interstate highway. We also know whether the house is groundwater dependent (in other words, whether it uses well water rather than being on a public water system). ${ }^{20}$ Figure 1.2 displays the housing transactions and horizontal producing wells included in this study.

Figure 1.2. Housing Transactions and Horizontal Wells in West Virginia (2006 - 2015)

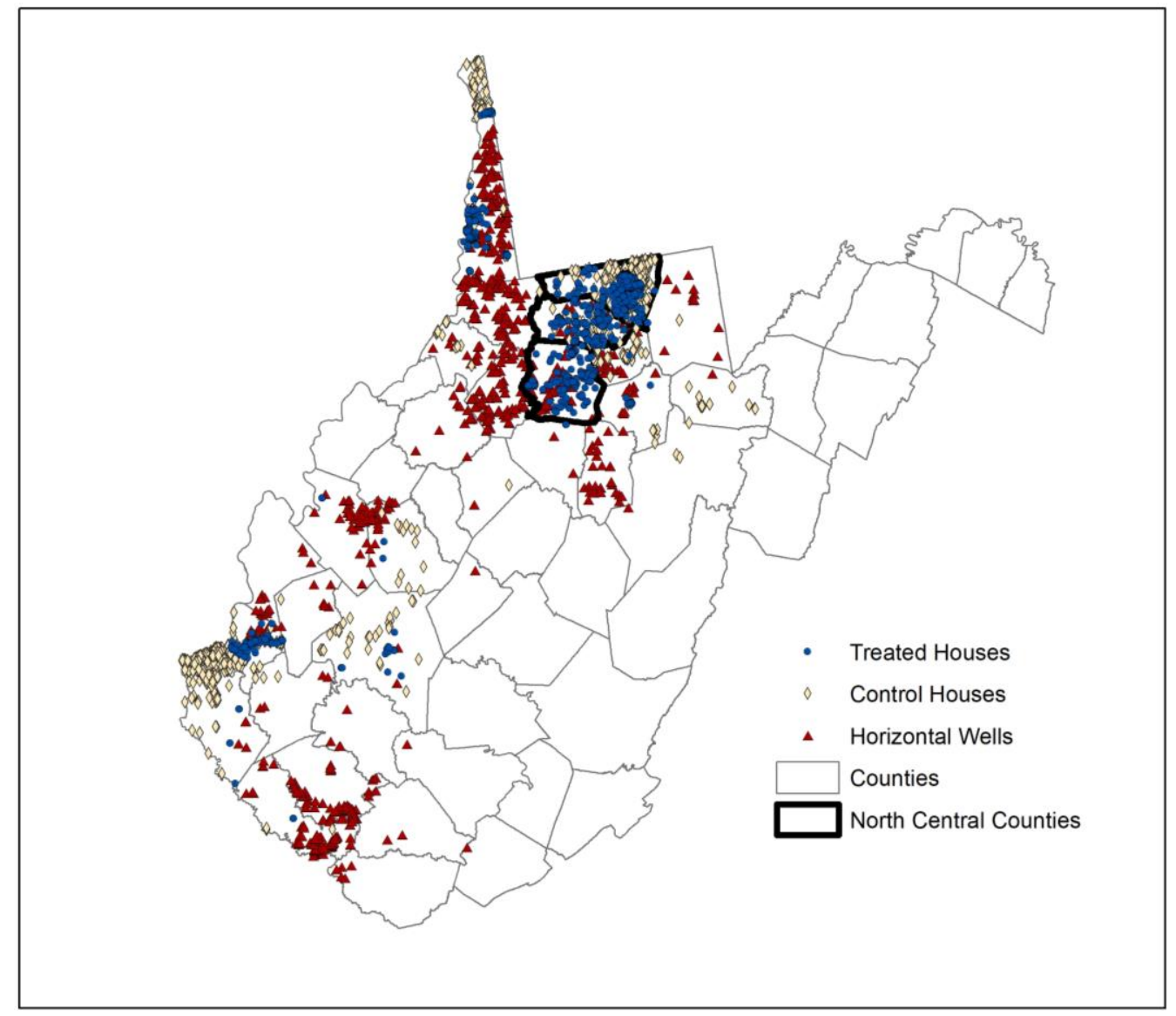

Notes: The figure shows treated and control houses from Specification 2 (as described above). Observations from areas of the state that are not in the same labor markets as the drilling activity, as well as observations where drilling began in the year of the sale, are excluded.

\footnotetext{
${ }^{18}$ In sensitivity analysis, we also consider a well active if there was drilling activity two-years before the sale.

${ }^{19}$ In our dataset, these major cities consist of Pittsburgh, PA, and Columbus, OH.

${ }^{20}$ ArcGIS shapefiles from the WV Water Development Authority, WV Infrastructure and Jobs Development Council, and the WV Office of GIS Coordination allowed us to determine if a house was located in a public water district.
} 


\subsection{Results}

The results of our estimation using the matched, pre-processed data for each specification are included in Table 1.3. We use two models to examine the impact of nearby drilling. Model 1 examines the marginal impact of having an additional well within 4 miles, and Model 2 includes an interaction term with groundwater dependency, which examines additional effects from being on well water due the potential impact from groundwater contamination. For comparison, we present hedonic models using our full, cleaned sample before matching in Appendix A2.

Table 1.3. CEM Results: Effect of Drilling Activity on Log Housing Prices in West Virginia (2006-2015)

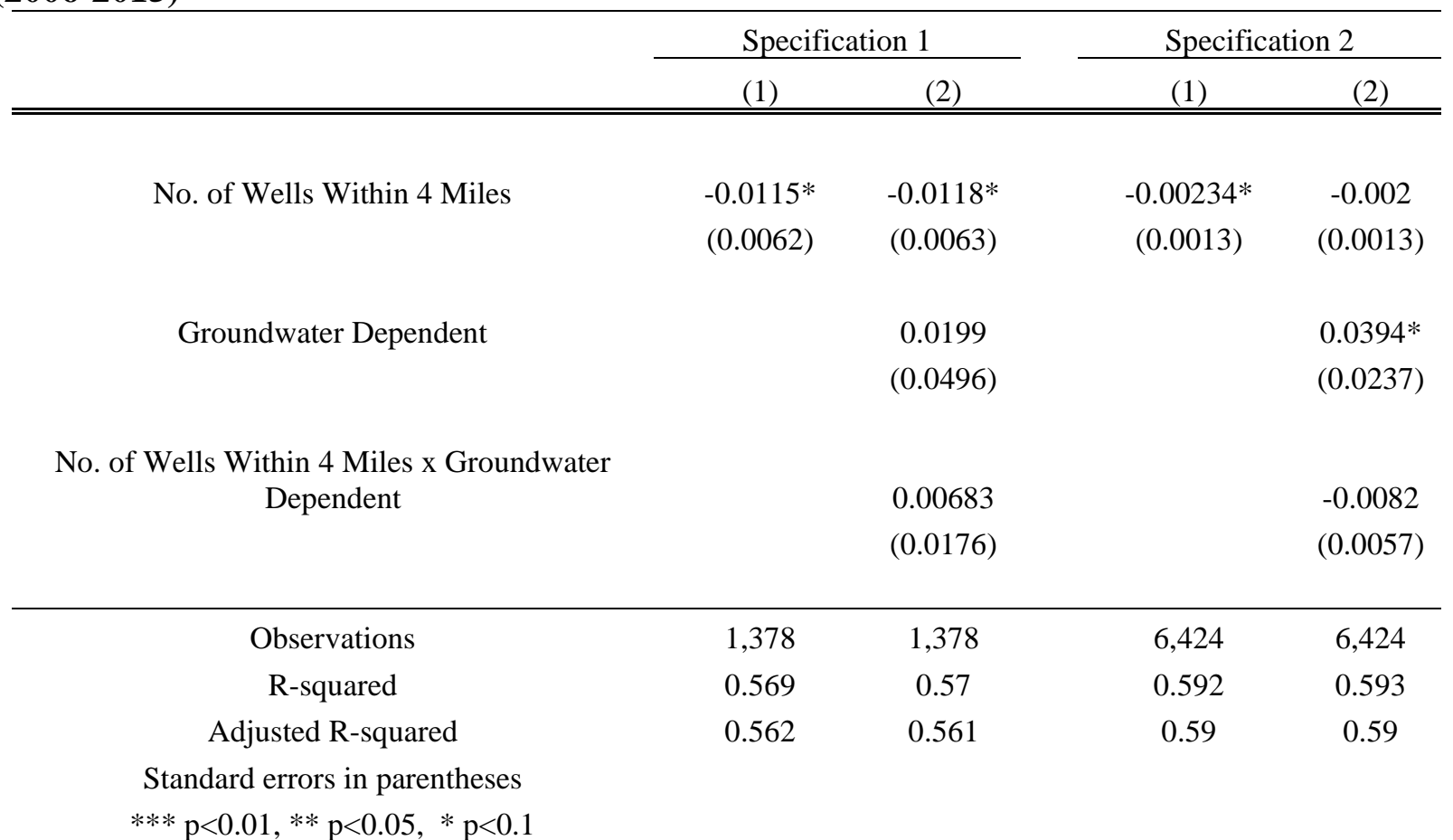

Notes: All models include housing characteristics; miles to the closest MSA, major city, and interstate; mining employment; county fixed effects and year fixed effects. Additionally, the Specification 2 models control for tract-level characteristics, including population density and the average number of bedrooms, bathrooms, square feet, acres, and age for all single-family houses in the tract in which the house is located, since these variables were not used in matching. To control for the matched pairs, CEM weights are also included in the regressions. 
The drilling activity measures in Table 1.3 suggest that there is a negative impact on price from being close to wells. In Model 1, using matching Specification 1, the results show that for every additional well within 4 miles, the price of a house decreases by $1.15 \%$, but there may be concerns about the sample size in this model. However, after making our matching less restrictive (Specification 2), we find similar results for Model 1, though of smaller magnitude. In this case, it appears that for every additional well within 4 miles, the price of a house decreases by $0.234 \%$. Overall, we find consistent results that the price of a house is reduced by nearby drilling activity.

Since previous studies suggest that groundwater dependency in Pennsylvania was an important determinant in whether shale development affected house prices, we also include an interaction term between groundwater dependency and the measure of the number of nearby wells. The estimates in both specifications are statistically insignificant, suggesting that there is not a differential effect from nearby drilling based on whether or not a house is on public or private water. It appears that all residents are concerned about nearby drilling activity regardless of water source. It also could be due to the fact that in local areas of West Virginia, residents have few alternatives when house searching, such that all "candidate" houses are either on public water or not.

When we use interacted county and year-of-sale fixed effects, we find similar results for Specification 2, but the estimates are no longer statistically significant in Specification 1 . When we use census tract fixed effects (and year fixed effects), only the interaction term between proximity to drilling and groundwater dependence in Specification 2 is statistically significant. ${ }^{21}$ However, for both of these additional analyses, the number of observations and the variation

\footnotetext{
${ }^{21}$ We also test using city fixed effects (based on mailing address) and find similar results.
} 
within the fixed effects is more limited. Nevertheless, they suggest that even with limited variation there are some negative capitalization effects from proximity to drilling. For completeness, we present these results in Appendix A3 and Appendix A4, respectively. It also does not appear that the timing of our drilling measure is affecting our results, as the results in Appendix A5, using two-year lags and contemporaneous measures are similar to Table 1.3.

\subsection{Sensitivity Analysis}

\subsubsection{Boom vs. Bust}

As previously mentioned, we use more updated housing data than previous studies, with housing sales through 2015. Given the boom and bust nature of resource extraction, this allows us to examine how house prices are impacted during both the boom and the bust, or slowdown, periods. For example, during the boom period, housing prices may have reflected the capitalization effects of the benefits during a time of growth. Alternatively, houses purchased as new shale gas development tapered off (the bust or slowdown period) may have sold for less because residents recognized the post-boom downturn or were more exposed to the negative externalities associated with shale development.

As indicated in Figure 1.1, shale gas production in West Virginia increased dramatically starting in 2010. However, the growth in shale gas withdrawals increased at a decreasing rate after 2011. For example, withdrawals were 113,773 million cubic feet in 2010 and 227,012 million cubic feet in 2011, representing an increase of almost 100 percent (EIA-A, 2017). In 2012, shale gas withdrawals were 344,847 million cubic feet, which represents a much lower 52 percent increase from 2011 (EIA-A, 2017). The increase has continued to decrease year over year since 2012. Residents that purchased houses in 2011 or before may have only been 
experiencing the boom, whereas residents purchasing houses in 2012 or after may be experiencing the bust. Therefore, we split our sample into boom and bust periods, using 2011 as the final year of the boom.

The results of splitting our sample into boom and bust periods are included in Table 1.4. We only include the results from Specification 2, since we have too few observations using the stricter matching specification after we split the sample. During the period up to 2011, in Model 1, there appears to be no effect from drilling. However, the estimate for overall drilling intensity during the boom period is positive and significant in Model 2, suggesting that local drilling is (overall) positively capitalized into house prices during this period. Consistent with the results found in Pennsylvania (conducted around the same time), houses with producing wells nearby that relied on a private water source still sold for less. It appears that residents on well water are negatively impacted by nearby shale development due to concerns with water quality, but residents as a whole may be indifferent to the development or positively inclined to it, driving up prices for those houses near drilling due to the employment and income opportunities in a time of shale gas production growth.

The results from the bust period tell a different story. In this case, nearby wells are negatively capitalized into housing prices in both specifications. Specifically, in Model 1, each additional well within 4 miles decreases the price of all houses (not just those on well water) by approximately $0.282 \%$. Unlike during the boom period, the interaction term between proximity to drilling and groundwater dependence is statistically insignificant. This suggests that when the production slows down and the drilling is not as intense, all residents negatively value being close to drilling, regardless of water source. 
Comparing the results from the boom and bust periods provide further insight into how residents value shale gas development. Residents may be indifferent to or even positively inclined toward drilling activity during a boom when they may be receiving other positive benefits (such as jobs) from local drilling. However, even during this time, residents who rely on well water appear to be concerned about water quality. As companies slow production, however, house prices are lower closer to drilling suggesting that the negative externalities associated with drilling activity outweigh the benefits.

Table 1.4. CEM Boom vs. Bust Results: Effect of Drilling Activity on Log Housing Prices in West Virginia (2006-2015)

\begin{tabular}{|c|c|c|c|c|}
\hline & \multicolumn{2}{|c|}{ Boom Period (2011 and Before) } & \multicolumn{2}{|c|}{ Bust Period (2012 and After) } \\
\hline & \multicolumn{2}{|c|}{ Specification 2} & \multicolumn{2}{|c|}{ Specification 2} \\
\hline & $(1)$ & (2) & $(1)$ & (2) \\
\hline \multirow[t]{2}{*}{ No. of Wells Within 4 Miles } & 0.0112 & $0.0173 * *$ & $-0.00282 * *$ & $-0.00288^{* *}$ \\
\hline & $(0.0068)$ & $(0.0071)$ & $(0.0013)$ & $(0.0013)$ \\
\hline \multirow[t]{2}{*}{ Groundwater Dependent } & & -0.0508 & & -0.0234 \\
\hline & & $(0.0592)$ & & $(0.0351)$ \\
\hline \multirow[t]{2}{*}{$\begin{array}{l}\text { No. of Wells Within } 4 \text { Miles } \\
\text { x Groundwater Dependent }\end{array}$} & & $-0.0404 * * *$ & & 0.00651 \\
\hline & & $(0.0143)$ & & $(0.0098)$ \\
\hline Observations & 1,086 & 1,086 & 3,231 & 3,231 \\
\hline R-squared & 0.6 & 0.605 & 0.593 & 0.594 \\
\hline $\begin{array}{l}\text { Adjusted R-squared } \\
\text { Standard errors in } \\
\text { parentheses } \\
* * * \mathrm{p}<0.01, * * \mathrm{p}<0.05, * \\
\mathrm{p}<0.1\end{array}$ & 0.589 & 0.593 & 0.589 & 0.589 \\
\hline \multicolumn{5}{|c|}{$\begin{array}{l}\text { Notes: All models include housing characteristics; miles to the closest MSA, major city, and interstate; mining employment; } \\
\text { county fixed effects and year fixed effects. Additionally, the Specification } 2 \text { models control for tract-level characteristics, } \\
\text { including population density and the average number of bedrooms, bathrooms, square feet, acres, and age for all single-famil } \\
\text { houses in the tract in which the house is located, since these variables were not used in matching. To control for the matched } \\
\text { pairs, CEM weights are also included in the regressions. }\end{array}$} \\
\hline
\end{tabular}




\subsubsection{Treatment Distance Rings and Buffer Area}

Our initial analysis considers a house to be treated if there was an active producing well within 4 miles. However, residents that live barely beyond 4 miles may benefit from the employment and income opportunities but do not experience the disamenities associated with living directly next to a well. For example, a resident that lives 6 miles away from a well may be employed in the oil and gas industry but not have to experience groundwater contamination. To ensure that we capture both the positives and negatives of nearby shale development, we use treatment distance rings of 0 to 4 miles and 4 to 8 miles. For example, a treatment ring of 4 to 8 miles would consider a house to be treated if there was an active well between 4 and 8 miles away from the house. Treatment distance rings should also help us observe a potential distance decaying effect.

We also use a different buffer. In our main analysis, we use a one-mile buffer area between the treated and control houses to ensure that there is a distinct difference between the two groups. To further ensure that we are isolating the effect of living close to drilling, in our models with distance rings, we use a larger buffer area of 2 miles. With a larger buffer area requiring potential control houses to be further away from well locations, it becomes less likely that these residents could potentially be affected by nearby drilling (either positively or negatively). For example, a buffer area of 2 miles using the treatment ring of 4 to 8 miles would require potential control houses to be at least 10 miles away from the closest active well.

Residents this far away from a well (but still within the spatial confinement of the matching specification) are less likely to be impacted by the drilling, which may make for a better control group. 
Table 1.5. CEM Treatment Distance Rings Results: Effect of Drilling Activity on Log Housing Prices in West Virginia (2006-2015)

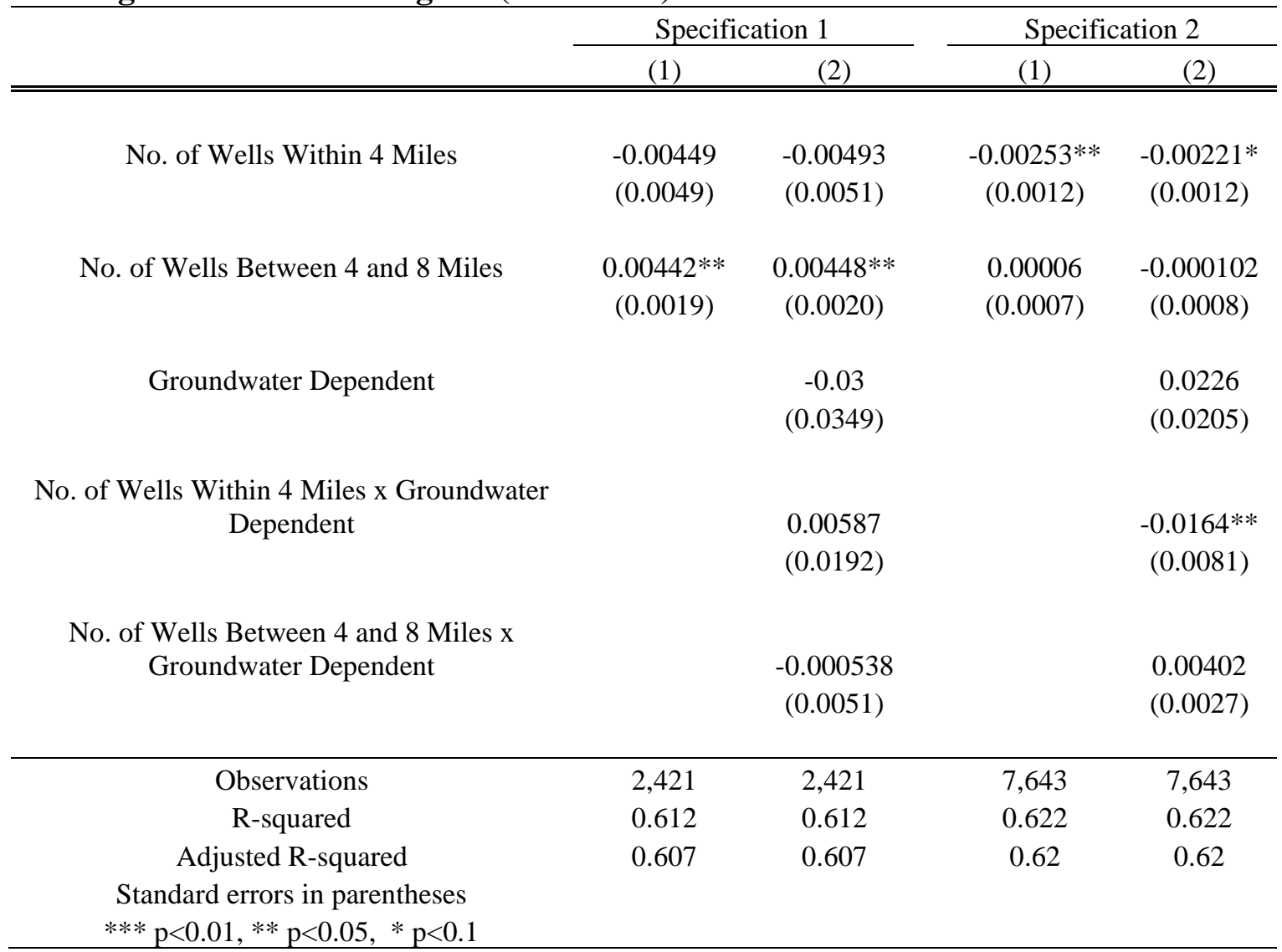

Notes: All models include housing characteristics; miles to the closest MSA, major city, and interstate; mining employment; county fixed effects and year fixed effects. Additionally, the Specification 2 models control for tract-level characteristics, including population density and the average number of bedrooms, bathrooms, square feet, acres, and age for all single-family houses in the tract in which the house is located, since these variables were not used in matching. To control for the matched pairs, CEM weights are also included in the regressions.

The results from using the treatment distance rings and a larger buffer area are included in Table 1.5. The results using Specification 2 indicate that houses that have a well within 4 miles sell for less. Specifically, each additional well within 4 miles will decrease the price of a house by less than 1 percent. Also, there are additional negative effects for those houses with a private water source.

Using matching Specification 1, our results suggest that houses located between 4 and 8 miles away may be benefiting from nearby drilling. For each additional well within 4 to 8 miles, it appears that the price of a house will increase by less than 1 percent. 
Overall, this suggests that the negative effect from shale development may be very localized, especially affecting houses closest to active wells. Residents of houses closest to wells may be disproportionately experiencing the negative externalities. Comparatively, other residents located nearby, but not directly next to a well, do not have to experience the negative externalities but may still receive the benefits. Therefore, the benefits of shale development appear to dominate. However, this result is only statistically significant using Specification 1, where we have only a very small number of treated houses.

\subsubsection{North Central West Virginia}

Monongalia, Marion, and Harrison Counties in north central West Virginia contain a large amount of the drilling activity in the state. For example, 17 percent of the wells in operation in 2014 were in these three counties. These counties are also more urbanized, have more housing transactions than much of the state, and comprise a single labor market. This is important because valuing amenities or disamenities using housing prices is more complicated when crossing labor markets where wages could also vary. Finally, these counties have more employment opportunities, comprising 20 percent of total employment in West Virginia in 2016 (BEA, 2018), and higher wages, suggesting that the impact of drilling may be different as there may be lower economic distress. Thus, we examine this region separately. The counties in this region are indicated by the bold outline in Figure 1.2.

The results for Monongalia, Marion, and Harrison Counties are presented in Table 1.6. We find similar results to that of our previous estimates for drilling activity. Specifically, we infer that residents prefer to have fewer wells nearby. Results from Model 1 using matching Specification 1 indicate that for every additional well within 4 miles, the price decreases by 
4.07\%. Specification 2 provides similar results, though of smaller magnitude. Consistent with our findings for the entire state, the interaction terms with drilling activity and groundwater dependency are statistically insignificant in both specifications. Again, unlike many of the previous studies in Pennsylvania (some of which focused on areas close by to this region), we find a negative capitalization of nearby shale gas development for all houses, not just those on groundwater.

Table 1.6. CEM Results: Effect of Drilling Activity on Log Housing Prices in North Central West Virginia (2006-2015)

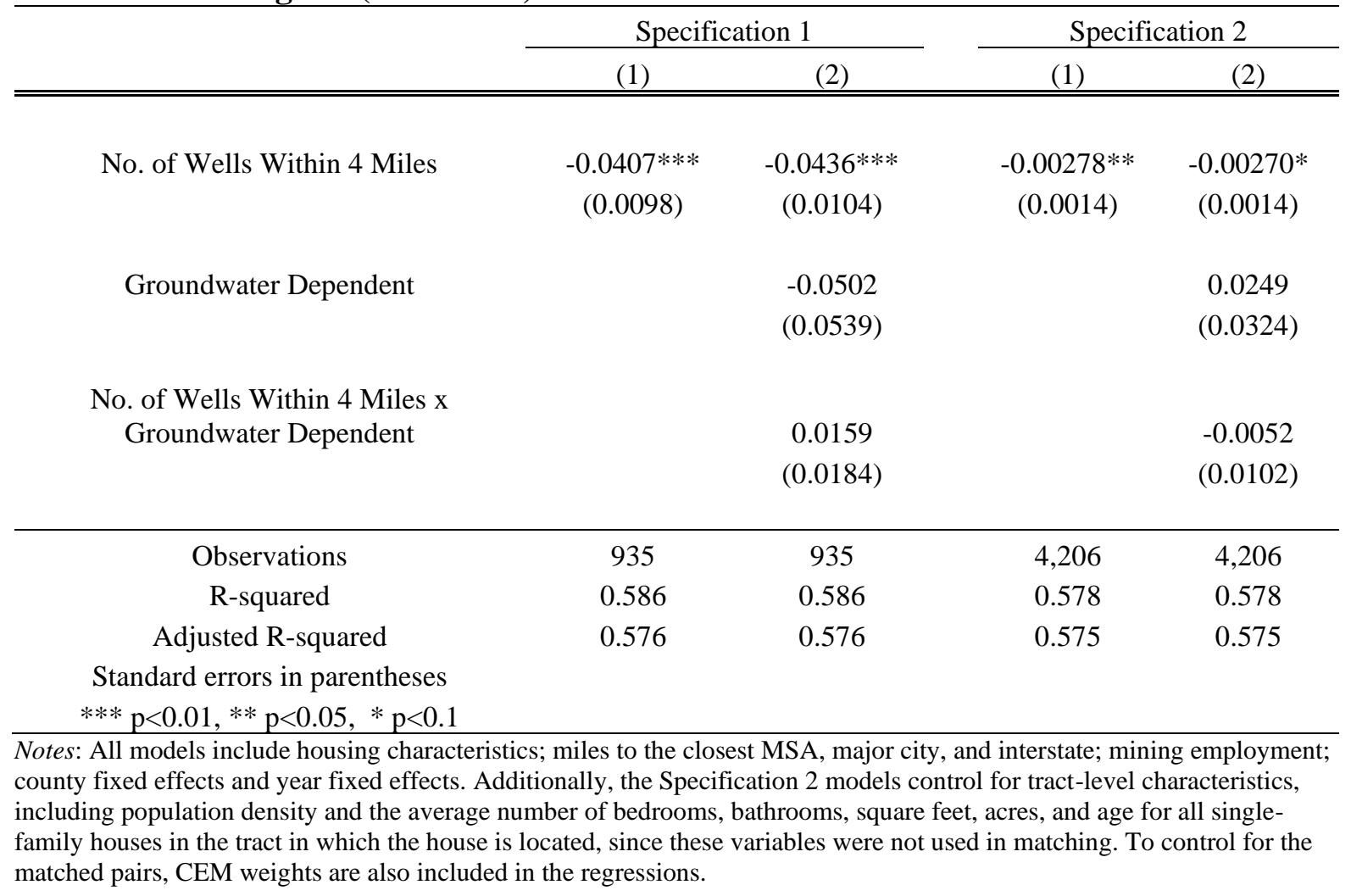

\subsection{Conclusion and Policy Implications}

The deployment of new technologies in drilling have led to increases in oil and natural gas development throughout the United States. In some cases, the development is taking place in regions with a long history of resource extraction and with experience with the associated boom 
and bust economies, which has been ignored by previous research. This experience may affect how households in these communities value the new drilling activity. If the resource-dependence has led to lower economic prospects, then new drilling activity may be a welcome source of employment and income. However, experience with the negative economic repercussions related to resource development may also may residents wary of new development. And, since new shale development also comes with negative externalities and other impacts, these may affect households' net valuation. In other words, people who have seen past resource extraction may also be more or less favorable to these impacts. Our findings contribute to the body of knowledge on the impacts of drilling activity, recognizing that these impacts vary regionally. Since we also use a longer period of time during which there was both drilling expansion and contraction, our results may also provide insight into how people value drilling activity beyond the initial boom period. Finally, we contribute to the overall hedonic literature by using an underutilized matching method, CEM, that addresses the limitations of traditional methods in housing markets with few transactions by creating a better counterfactual.

Using data from West Virginia, with its long history of resource extraction, we examine the impact of shale natural gas development on nearby housing prices. We find evidence that nearby shale development lowers housing prices, suggesting that, even in places with a history of resource extraction, residents are willing to pay a premium to live farther from the negative externalities and unappealing aesthetics of wells. Based on the mean price and number of wells within four miles for treated houses (using Specification 2), we find that houses near active wells sell for approximately $\$ 2,434$ less. This is a significant amount of West Virginia's median income of $\$ 41,751$ (Census, 2018). Also, given the inclusion of the lagged mining employment 
variable, our findings can be interpreted as net of the potential labor demand effects due to mining.

We also find some evidence that the negative capitalization effect varies over time and attenuates over space. For example, for houses on public water, we find a positive capitalization effect for houses that were sold during the boom period when there was a time of rapid growth. However, during that same time, there was a negative effect for houses with a private water source, suggesting concerns about groundwater contamination and water quality. As the drilling boom slowed down and turned to a bust, there appears to be a negative capitalization effect on all houses (regardless of water source). Additionally, our results indicate that houses that have a well within 4 to 8 miles sell for more, suggesting that shale gas development may drive up prices for homes in drilling communities where people experience the employment and income benefits, but are not directly next to wells (thus they do not experience the negative externalities).

While short-term models may not fully inform the long-term impacts of shale gas development, our results suggest that there may be a role for policy. For example, some states have started adopting per-well impact fees associated with shale activity (Gopalakrishnan and Klaiber, 2013; Black et al., 2017). Black et al. (2017) use Pennsylvania, Ohio, and West Virginia lease data and find that leasing by energy firms declined dramatically after a fee was enacted. Policymakers may also want to consider policies that address permanent environmental damage from shale gas development. For example, to deal with groundwater contamination concerns, they might enact more formal water testing regulations and potential remediation. Having policies in place to limit environmental impacts may change the value residents place on shale gas development. For example, residents' willingness to live near shale gas development may 
change if they have little concern over the negative externalities associated with unconventional drilling. Such policies will also help maintain the integrity of the nearby property into the future when the shale gas has been extracted. Otherwise, contaminated properties may hamper the ability of these regions to diversify into other industries, resulting in lower long-term economic prospects.

While the results of this study are based on analysis in West Virginia, they provide insights into how households in similar regions may value future energy development. For example, as shown in Stephens et al. (2013), factors that affect growth in Appalachia (of which West Virginia is a part) are similar to those that affect growth in other lagging U.S. regions. Additionally, Papyrakis and Gerlagh (2007) find that resource-dependent states grew slower than other states, and James and Aadland (2011) find the same for U.S. counties. Thus, we might expect households in other resource-dependent regions to worry about the long-term impacts of new energy development, despite the potential short-term income and employment gains. 


\section{Chapter 2}

\section{The Capitalization of Metro Rail Access in Urban Housing Markets}

\subsection{Introduction}

Metro rail systems (also known as subways or metros) have become increasingly popular in many U.S. cities. This type of transportation can provide numerous benefits to local residents, such as providing affordable and sustainable transportation, increased connectivity to jobs and amenities, reduced traffic congestion and emissions, and increased economic activity (Mohammad et al., 2013). These benefits often justify the use of public funds to finance new transit development. However, metro rail systems are also associated with negative externalities, such as noise and crime (Bowes and Ihlanfeldt, 2001), especially for residents who live close to them.

One way to assess the impact of metro rail access is to examine if proximity to metro lines is capitalized into house prices (Diao et al., 2017; Gibbons and Machin, 2005; Li et al., 2016; McMillen and McDonald, 2004; Redfearn, 2009; Sadayuji, 2018; Wagner et al., 2017). In Los Angeles, California, billions of dollars are being spent on metro rail development, thus, it is important to understand the value that residents place on this development. Additionally, there is significant demographic heterogeneity in the populations along the Los Angeles metro lines. Thus, there may be differences in preferences and other factors, which may lead to heterogeneous valuations of proximity to rail access and the value of rail access may vary among communities (McMillen and Redfearn, 2010).

Using data from before and after the construction and opening of the Gold and Exposition (Expo) Lines in Los Angeles, California, we estimate hedonic spatial difference-in-differences models to assess how the new metro rail lines are capitalized into nearby house prices. If the 
benefits of living near a metro station outweigh the costs, then house prices should increase.

However, house prices may decrease if the negative externalities imposed on living near a metro station outweigh the benefits from public transit access.

This paper contributes to the empirical literature on intra-city urban metro and subway lines and housing prices in a number of important ways. First, we examine the impact of multiple new metro lines in which the capitalization effect may vary across neighborhoods. Most related research using hedonic spatial difference-in-differences models primarily contain case studies focusing on one metro line in a single community. By examining the impact among different communities, we are able to provide a more complete picture of the value of metro rail development throughout a region.

Second, we provide further insight into potential heterogeneity in the valuation of metro rail access between communities that many other studies have overlooked. Understanding how different populations value metro rail access may help promote public transportation infrastructure in areas that positively value access and are more likely to use metro rail systems.

Lastly, we examine the impact of proximity to stations in a relatively new metro rail system. Most previous related studies assess the capitalization effect of metro rail lines that have been around for a long time. For example, the first metro line in Chicago opened in 1943, whereas the first line in Los Angeles did not open for almost another 50 years. Additionally, because Los Angeles does not have a long history of public transportation, this may result in residents valuing metro rail access differently. We also use more updated housing data than previous studies, thus our results may be more reflective of current attitudes towards rail access. For example, residents may value proximity to metro stations differently if there are new 
transportation alternatives that were not available during the timeframes of previous studies (i.e. Uber or other ride-share services).

Our results indicate that there is indeed heterogeneity in terms of the value that residents place on proximity to metro lines. For houses near Gold stations, there appears to be an overall positive capitalization effect. While there does not appear to be any effect from the "announcement" of the new line, houses in close proximity to a station sold for approximately 3$4 \%$ more after the opening. Additionally, our results indicate that the positive capitalization effect is being driven by the lower/middle class communities along the line, suggesting that infrastructure in these areas may be important for the future success of metro rail, and public transit in general.

For houses near Expo stations, the results are a bit more mixed. Some residents prefer to live near the new line, while others do not. Some residents in the lower income communities along this line positively value the benefit of affordable public transportation, and the access it provides to travel to downtown Los Angeles or to other areas along the line. However, others appear not to benefit from this proximity, experiencing only the negative externalities associated with living close to stations. Additionally, unlike the Gold Line, we find evidence of positive "announcement" effects, where house prices appreciated well in advance of the actual opening with little to no impact once the stations opened.

In what follows, we provide some background on the Los Angeles metro rail system and an overview of the previous literature. Next, we describe our econometric approach and the data used in the analysis. Finally, we discuss our results, and conclude with some implications of our analysis. 


\subsection{Los Angeles Metro Rail System}

Providing an alternative to its congested freeways, the Los Angeles metro rail system provides low-cost public transit to many residents; over 9.7 million people rode the metro in 2014 (L.A. Metro - a). The Los Angeles metro rail system is also relatively new, with the addition of the Gold and Expo Lines in 2003 and 2012, respectively. The new lines run to the downtown area and connect communities throughout the region. For example, the stations included in this analysis which are along the Gold Line extend from the San Gabriel Valley to East Los Angeles, as shown in Figure 2.1, and the Expo Line runs from Culver City to the North University Park neighborhood of Los Angeles. None of these communities had rail access prior to the opening of the lines.

Expansions of the Gold and Expo Lines continue, with the most recent extensions bringing the total costs of the lines to $\$ 2.8$ billion and $\$ 2.4$ billion, respectively (L.A. Metro - b). It is expected that the Los Angeles metro network will continue to expand based on the voterapproved half-cent sales tax called Measure R (Boarnet et al., 2015). With billions of dollars being spent on metro rail development, it is important to understand the value that residents place on this development. Additionally, differences in preferences and other factors may lead to heterogeneous valuations of proximity to rail access and the value of rail access may vary among communities, differing based on income levels, demographics, and other factors (McMillen and Redfearn, 2010).

As suggested by Boarnet et al. (2015), the characteristics of areas surrounding the Gold and Expo Line stations are different in a number of ways from areas that previously got metro line access. For example, neighborhoods surrounding major parts of the Expo Line fall under the category of "very low income" (Boarnet et al., 2015). This is in contrast to the neighborhoods 
around other lines where the median household income is considered "low income" (Boarnet et al., 2015). Additionally, the Gold Line which passes through Little Tokyo and Chinatown has large non-Hispanic Asian populations (Boarnet et al., 2015). Table 2.1 presents demographic information for the areas surrounding the Gold and Expo stations, providing further descriptive evidence that these areas are quite different. ${ }^{22}$ For example, the mean household income for Gold station areas is nearly $\$ 20,000$ more than Expo station areas. Additionally, the population around Gold station areas is higher educated, more white, and has a higher labor force participation rate, and a lower unemployment rate.

Table 2.1. Means of Key Characteristics for Gold and Expo Station Areas (2010)

\begin{tabular}{cccc} 
& Gold Station Areas & & Expo Station Areas \\
\cline { 2 - 2 } Household Income & 62,245 & & \\
Percent White & 51.06 & & 33,709 \\
Percent Bachelor's Degree or Higher & 28.57 & & 34.28 \\
Labor Force Participation Rate & 60.63 & 23.03 \\
Unemployment Rate & 9.44 & 55.34 \\
\end{tabular}

Overall, the population that lives along the Gold and Expo Lines is more racially diverse and lower income than in areas where the access to metro rail lines has been previously studied. Therefore, the value residents place on low-cost public transportation in these communities may be different than in other regions. For example, residents in very low income areas may positively value the opening of a line more than those in higher income areas due to the added benefit of cheap, accessible public transportation. However, it may also be the case that residents

\footnotetext{
${ }^{22}$ These characteristics are based on the census tracts that the stations are located in.
} 
in relatively higher income areas value it more because they may be more likely to use the new lines to travel to their jobs in downtown Los Angeles or to other areas accessible by these lines.

\subsection{Previous Literature}

A number of previous studies have examined the impact of metro rail access on property values. For example, McMillen and McDonald (2004) consider the impact of a new rapid transit line in Chicago. They find that the new line is positively capitalized into house prices.

Additionally, they provide evidence that house prices were already being affected by proximity to the stations soon after the announcement of the new line, suggesting that residents anticipated the opening. Examining the opening of the Circle Line in Singapore, Diao et al. (2017) also find anticipation effects, with their results suggesting that house prices began increasing as early as one year prior to the opening. Another study in Singapore also provides evidence that apartment prices increase in response to the expansions of the mass rapid transit system (Fasselmayer and Liu, 2018).

Numerous other studies also find that metro rail access increases house prices. For example, Gibbons and Machin (2005) examine the impact of new metro rail stations in London. Their results suggest that the new stations are positively capitalized into house prices and metro rail access is a valued amenity for nearby residents. Li et al. (2016) quantify the capitalization of subway construction in Beijing, China, and provide evidence of a positive impact of subway proximity on property values. Evidence of positive capitalization effects from metro rail development can also be shown across many other different regions and countries, including Atlanta (Bowes and Ihlanfeldt, 2001; Nelson, 1992), San Francisco (Landis et al., 1995), Washington, D.C. (Damm et al., 1980), Miami (Gatzlaff and Smith, 1993), Toronto (Bajic, 1983; 
Dewess, 1976), Seoul (Bae et al., 2003), Taipei (Lin and Hwang, 2003) and three metropolitan areas in the Netherlands (Debrezion et al., 2011). Baum-Snow and Kahn (2000) show that metro rail transit upgrades increase house prices in five major U.S. cities.

However, there are several studies that suggest that intra-city rail access may not always be perceived as a net benefit or that the negative externalities may outweigh the benefits. Using a proposed light rail line that was ultimately not built as a counterfactual, Wagner et al. (2017) assess the impact of the Tide light rail on nearby property values in Virginia. In contrast to the results of other studies, they find that proximity to light rail decreased housing prices. CaminsEsakov and Vandegrift (2018) find no statistically significant impact of a New Jersey light rail extension on house prices. Relevant to the current study, Redfearn (2009) examines the impact of the opening of the Red and Gold metro rail Lines on house prices in Los Angeles. Using a locally-weighted regression, his results suggest there is no capitalization effect of access to these transit lines. While Redfearn (2009) examines the capitalization effect of metro rail access in Los Angeles, we examine different areas (the Gold Line examined in Redfearn (2009) does not include the Eastside Extension), use more recent data, and assess the impact of each line individually. Additionally, the demographics along these lines are quite different.

Other previous research suggests that heterogeneity between regions could explain these findings due to residents valuing metro rail access differently. For example, Los Angeles is comprised of complex local housing markets in which house prices may be less or more responsive to increased access (Redfearn, 2009). Additionally, McMillen and Redfearn (2010) find that the effect of access to rapid transit lines varies across neighborhoods within Chicago. Collectively, previous research suggests that income levels, demographics, and other factors, may result in residents valuing metro rail access differently. 


\subsection{Econometric Approach}

A common non-market valuation technique, which can be used to assess the value of metro rail access, is the hedonic pricing method. Introduced by Rosen (1974), hedonic models have been used extensively to examine how amenities and disamenities are capitalized into house prices. Since individual characteristics of a house cannot be sold separately, the hedonic method disaggregates the attributes of the house to reveal the marginal willingness to pay for each specific characteristic (Taylor, 2003). For example, house prices are a function of the attributes of the house (bedrooms, bathrooms, square feet, etc.) as well as the surrounding area (i.e. amenities and disamenities), including proximity to a metro rail station.

To estimate this effect, we follow Wagner et al. (2017) and use a hedonic difference-indifferences model, which helps mitigate the potential bias due to the presence of observable and unobservable locational characteristics that are correlated with proximity to metro stations. Using transactions data before and after the lines opened should help generate a causal effect by examining how proximity to a specific metro station is capitalized into house prices, controlling for other factors that could affect the price of a house, including spatial fixed effects to mitigate omitted variable bias (Kuminoff et al., 2010; Kuminoff and Pope, 2014). Therefore, we estimate the following hedonic spatial difference-in-differences model:

$$
\log (\text { Price })_{i t}=\beta_{0}+\beta_{1} \text { Post }+\beta_{2} \text { Treated }+\beta_{3}(\text { Post } x \text { Treated })+\beta_{4} H_{i t}+\theta_{j}+\eta_{t}+\omega_{s}
$$


Where $\log (\text { Price })_{i t}$ indicates the natural $\log$ of the normalized house price ${ }^{23}$, and $H_{i t}$ are the attributes of the house. We also include an indicator variable, $\theta_{j}$, for the elementary school attendance zone of the house. Elementary school attendance zone fixed effects should help control for any time-invariant spatial components, including school quality, as the previous literature (Black, 1999) has shown that residents pay a premium to live in better school districts. Additionally, the elementary school attendance zones are relatively small and houses that are near each other may be in different attendance zones. We also include an indicator variable for the year the house was sold, $\eta_{t}$, to address any temporal concerns. Since our descriptive analysis indicates that the areas where each specific station are located differ on income levels, demographics, and other factors, a station fixed effect, $\omega_{s}$, is also included.

A house is considered Treated if it is within the treatment distance. To examine possible distance decaying effects, we consider houses to be treated using several different distances, including 0.25 miles, 0.5 miles and 0.75 miles. To ensure a distinct difference between the treated and control groups, we exclude houses from our analysis that are within a 0.25 -mile buffer around each treatment distance. For example, using a treatment distance of 0.25 miles, houses that are within one-quarter a mile of a station would be considered treated, and only houses that are farther than 0.5 miles away would be potential controls. This buffer area ensures that we are not including houses that are across the street from a treated house and barely outside of the treatment distance in our control group. The variable Post indicates those houses that were sold after the treatment was received. To ensure that a house was sold either before or after treatment, observations in the same year as the treatment are excluded.

\footnotetext{
${ }^{23}$ The natural log of the price minimizes the impact of outliers and allows changes in characteristics to have percentage effects on housing prices.
} 
The variable of interest is the interaction term between Post and Treated. A positive and statistically significant estimate would suggest that households perceive living in proximity to a metro station to be a net benefit. In contrast, a negative and statistically significant estimate would suggest that residents find that the negative externalities from the station outweigh the convenience of the proximity to public transit and its benefits.

We consider several types of treatment. In addition to examining how the opening of the metro lines impacts house prices, we also use the start of construction to assess whether residents anticipated the opening. For example, house prices may begin to increase (or decrease) once construction starts if residents recognize the potential benefit (or cost) of living in proximity to the line in the future. By using the start of construction as well as the opening of the lines, we examine how house prices were impacted at every stage of the process. Additionally, since the areas that each specific line travels to are likely to be different in a number of ways, we examine the Gold and Expo stations separately.

As we further explain below, we also conduct several sensitivity analyses to explore additional heterogeneity in terms of the capitalization effects. First, we use a different set of control houses to verify that the effect of living in close proximity to the physical locations of the stations is not sensitive to the control group to which we are comparing our treated houses. Second, we use quantile regression to assess how the capitalization effect differs based on different ranges of house prices. Lastly, we extend our anticipation analysis by using the formations of the Gold and Expo Line Construction Authorities as our treatment years (1999 and 2003, respectively). 


\subsection{Data}

For our analysis, we use data on single-family homes sold in Los Angeles from 1995 to 2014 from DataQuick. The data include characteristics of the house, such as bedrooms, square feet, year built, year sold, location (latitude and longitude), and the sale price. In order to adjust for inflationary and deflationary periods and make prices comparable across time, housing prices are normalized in 2000 dollars. We also only include houses that were considered an arms-length transaction to ensure that each sale is a market transaction. Additionally, we remove observations with missing or zero values for key variables, as well as observations with outliers. As suggested by Humphreys and Nowak (2017) and others, we use approximately the $1^{\text {st }}$ and $99^{\text {th }}$ percentiles as the limits of the bounds for each characteristic of those transactions we retain.

Data on the Gold and Expo Lines in Los Angeles come from Metro Primary Resources and include information on when construction started and when the lines opened (Metro Primary Resources). Data on the location of the stations come from Metro Developer (Metro Developer). The stations along the Gold Line that are included in this analysis opened in two different time periods. For the Gold Line that runs from Union Station to the Sierra Madre Villa Station in the San Gabriel Valley (Phase 1), construction began in 2000 and the line opened in 2003. For the Eastside Extension, which runs from Union Station to the East L.A. Civic Center Station, construction began in 2004 and the line opened in 2009. For the stations along the Expo Line, which extends from Culver City to the LATTC/Ortho Institute Station in the North University Park neighborhood of Los Angeles, construction began in 2006 and the line opened in 2012. Figure 2.1 displays the Gold and Expo stations used in this analysis, as well as a few well-known Los Angeles locations to use as reference points. 
Figure 2.1. Gold and Expo Stations Included in the Analysis

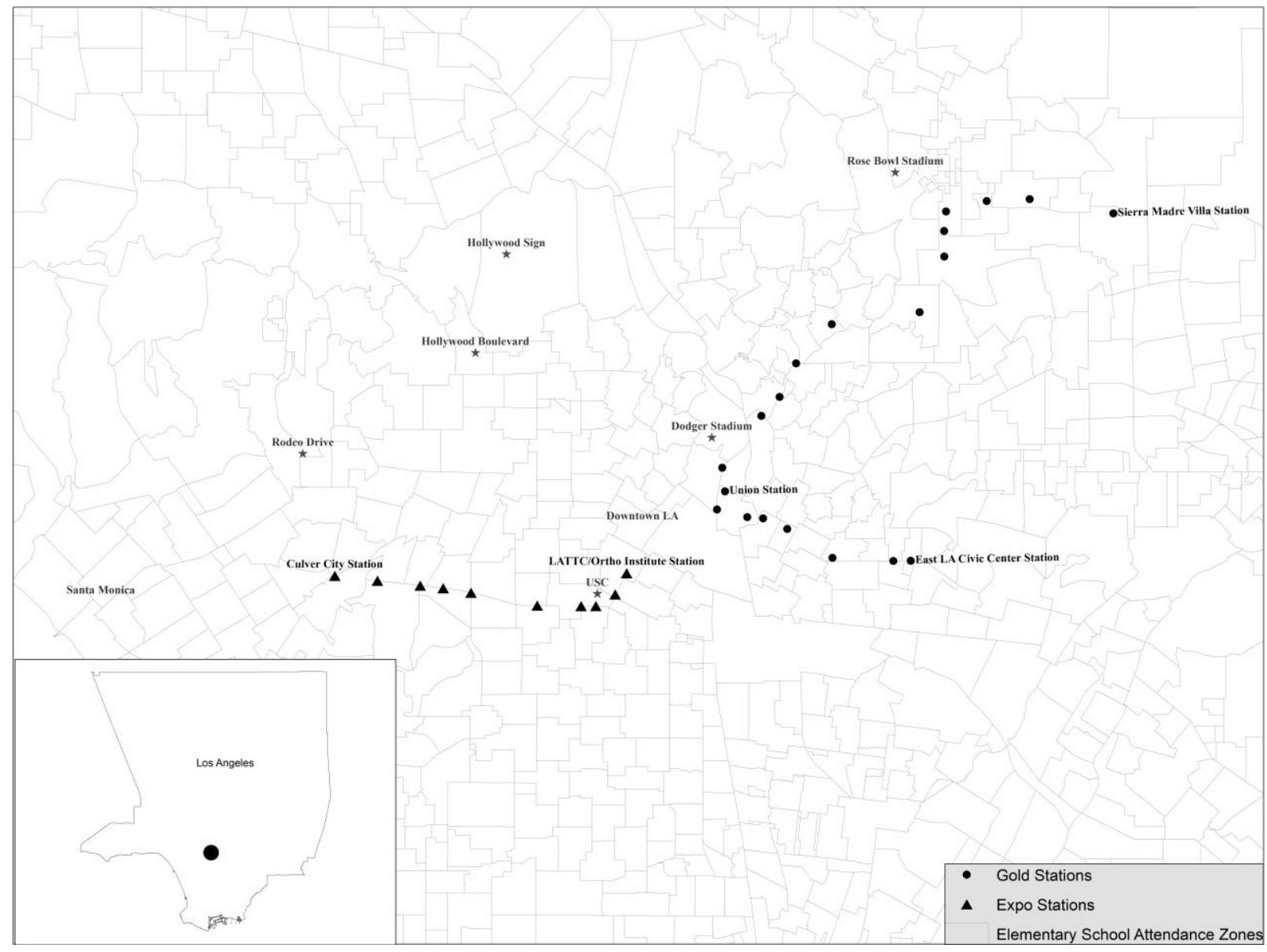

Using ArcGIS and STATA, we determined the proximity of houses to metro stations.

Once the distance to the closest station was determined, we followed McMillen and McDonald (2004) and Diao et al. (2017) and removed any observations that are farther than 1.5 miles from any station. These observations are removed to avoid any boundary discontinuity issues, since this distance is what is typically considered walking distance (Diao et al., 2017). ${ }^{24}$

Table 2.2 includes the means of key variables for the treated and control houses using a treatment distance of 0.25 miles. We separate the summary statistics into different subsamples based on when the houses were sold to show how the price and characteristics of the houses

\footnotetext{
${ }^{24}$ We also limit our control group to houses sold within 2 miles, and find similar results.
} 
changed over time. Specifically, we present the means for only those houses sold pregroundbreak, those sold post-groundbreak but still pre-open, and those sold post-open. We also separate the sample into houses near Gold Line stations and houses near Expo Line stations to show how the houses differ between the areas. 
Table 2.2. Summary Statistics for Key Variables

\begin{tabular}{|c|c|c|c|c|c|c|c|c|c|c|c|c|}
\hline & \multicolumn{6}{|c|}{ Houses Near Gold Stations } & \multicolumn{6}{|c|}{ Houses Near Expo Stations } \\
\hline & \multicolumn{2}{|c|}{ Pre-Groundbreak } & \multicolumn{2}{|c|}{$\begin{array}{l}\text { Post-Groundbreak/Pre- } \\
\text { Open } \\
\end{array}$} & \multicolumn{2}{|c|}{ Post-Open } & \multicolumn{2}{|c|}{ Pre-Groundbreak } & \multicolumn{2}{|c|}{ Post-Groundbreak/Pre-Ope } & \multicolumn{2}{|c|}{ Post-Open } \\
\hline & $\begin{array}{c}\text { Treated } \\
(\mathrm{n}=1,124) \\
\end{array}$ & $\begin{array}{c}\text { Control } \\
(\mathrm{n}=19,099) \\
\end{array}$ & $\begin{array}{l}\text { Treated } \\
(\mathrm{n}=479) \\
\end{array}$ & $\begin{array}{c}\text { Control } \\
(\mathrm{n}=8,178) \\
\end{array}$ & $\begin{array}{c}\text { Treated } \\
(\mathrm{n}=1,476) \\
\end{array}$ & $\begin{array}{c}\text { Control } \\
(\mathrm{n}=23,245) \\
\end{array}$ & $\begin{array}{c}\text { Treated } \\
(\mathrm{n}=1,007) \\
\end{array}$ & $\begin{array}{c}\text { Control } \\
(\mathrm{n}=21,701) \\
\end{array}$ & $\begin{array}{l}\text { Treated } \\
(\mathrm{n}=291) \\
\end{array}$ & $\begin{array}{c}\text { Control } \\
(\mathrm{n}=5,885) \\
\end{array}$ & $\begin{array}{l}\text { Treated } \\
(\mathrm{n}=102)\end{array}$ & $\begin{array}{c}\text { Control } \\
(\mathrm{n}=2,194) \\
\end{array}$ \\
\hline House Price & $178,982.10$ & $237,118.50$ & $273,322.01$ & $322,819.10$ & $335,133.6 c$ & $415,728.90$ & $202,115.40$ & $263,780.60$ & $225,779.80$ & $327,131.30$ & $264,417.70$ & $359,310.90$ \\
\hline Bedrooms & 3.31 & 3.07 & 2.92 & 2.93 & 2.69 & 2.85 & 3.15 & 3.22 & 2.96 & 3.10 & 3.14 & 3.04 \\
\hline Square Feet & $1,651.74$ & $1,666.93$ & $1,501.86$ & $1,611.89$ & $1,456.59$ & $1,606.80$ & $1,592.65$ & $1,903.58$ & $1,461.52$ & $1,817.45$ & $1,580.50$ & $1,825.37$ \\
\hline $\begin{array}{l}\text { Age } \\
\text { Mi. to Closest }\end{array}$ & 67 & 56.97 & 62.57 & 59.71 & 55.50 & 63.19 & 71 & 68.55 & 78.05 & 74.94 & 83.94 & 76.67 \\
\hline Station & 0.18 & 0.97 & 0.18 & 0.97 & 0.17 & 0.97 & 0.19 & 1.03 & 0.19 & 1.03 & 0.19 & 1.02 \\
\hline
\end{tabular}


As Table 2.2 shows, the houses near the Gold and Expo stations are quite different. For example, houses near the Gold stations were cheaper than those near Expo stations pregroundbreak. However, once construction started and after the stations eventually opened, houses near Gold stations were substantially more expensive. Additionally, houses near the Expo stations have more bedrooms on average, and are older. These differences in house characteristics may be reflective of income levels and other factors that may result in residents valuing low-cost public transportation differently.

The summary statistics table also shows that for both lines, treated houses were purchased for less, regardless of when they were sold. Figures 2.2 and 2.3, which present parallel trends plots for average house prices of the treated and control groups (using a 0.25-mile treatment distance), provide further descriptive evidence.

Figure 2.2 displays the parallel trends plot for houses near the Gold Line Eastside Extension stations with vertical lines at the groundbreak year (2004) and open year (2009). ${ }^{25}$ Although we are unable to find an exact announcement date, the Metro Gold Line Construction Authority (also currently known as the Foothill Gold Line Construction Authority) was formed in 1998 and was tasked with designing and building Phase 1 of the Gold Line stations in 1999, including the Eastside Extension. ${ }^{26}$ Therefore, since it is reasonable to assume that an announcement would have been made around this time, we also include a vertical line at 1999 to assess further any "announcement" effects.

\footnotetext{
${ }^{25}$ We show the vertical lines based on the Gold Line Eastside Extension stations so that the later years of our parallel trends plot do not include the houses that are near stations that have already been opened in Phase 1.

26 This independent transportation planning, design, and construction agency was created by the California State Legislature, SB 1847 (later updated in 2011-AB706 and 2012-AB1600). More information can be found at: https://foothillgoldline.org/construction_authori/construction-authority/
} 


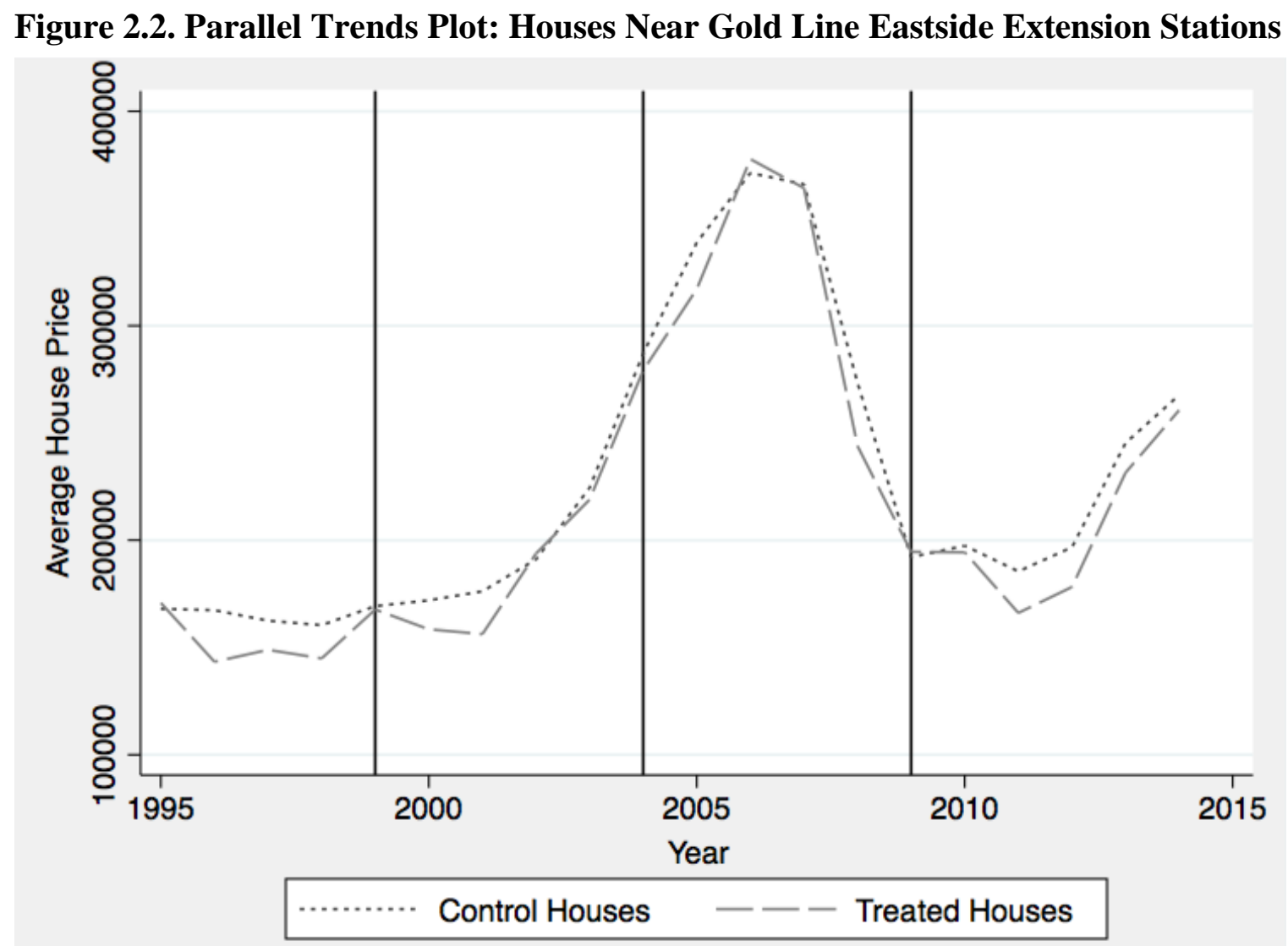

Figure 2.2 indicates that the house price gradients for the treated and control houses in the areas surrounding what are now the Gold Line Eastside Extension stations followed similar trends pre-“announcement"/pre-groundbreak and pre-open with a divergence in trends apparent in the "announcement" and opening years. For example, there was a slight decrease in treated house prices once the "announcement" was made, followed by prices well surpassing pre"announcement" levels once construction started. After the lines opened, there was an immediate price decrease for those near the stations, with a steady increase a few years after the openings. Overall, the figure provides descriptive evidence that the parallel trends assumption for a difference-in-differences analysis is satisfied, and the "announcement"/groundbreak and opening of the Gold Line Eastside extension stations are driving the changes in house prices. 
Figure 2.3 presents a parallel plot for the treated and control houses in the areas near the Expo stations with vertical lines at the groundbreak year (2006), open year (2012), and three years prior to the groundbreak year (2003). The trends are similar, although the impact on prices from the "announcement"/groundbreak and opening is less clear. ${ }^{27}$

\section{Figure 2.3. Parallel Trends Plot: Houses Near Expo Stations}

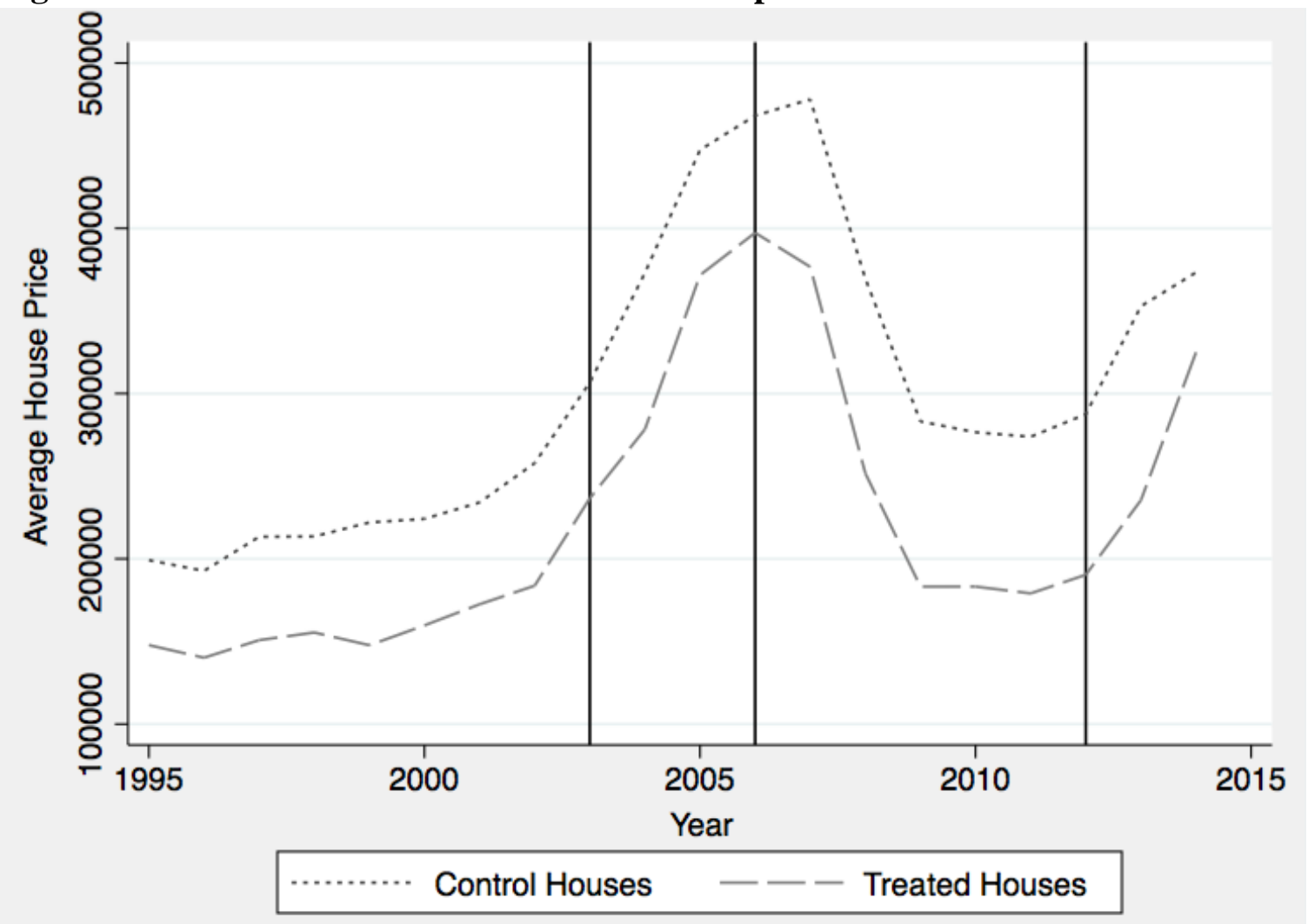

${ }^{27}$ The Exposition Metro Line Construction Authority was formed in 2003 (California State Legislature, SB 504). 


\subsection{Results}

Since the areas the lines travel to and the timing of the station's openings are different in a number of ways, we examine the Gold and Expo lines individually. ${ }^{28}$ Table 2.3 shows the results of only including houses in which the closest station is on the Gold Line. We use three models that include data from different subgroups to examine when the impact of any capitalization effect may have occurred. Model 1 compares those housing transactions before the groundbreaking or beginning of construction, compared to those after the groundbreaking but before the station opened. Model 2 includes all housing transactions after the groundbreaking, comparing those houses sold before the line opened to those after it opened. Finally, Model 3 includes all transactions in the sample, where the treatment is the opening of the line. For each model, three different treatment distances are used, 0.25 miles, 0.5 miles, and 0.75 miles.

\footnotetext{
${ }^{28}$ The results of combining all stations together are included in Appendix A6. These results also provide the estimates of our key house characteristics and show that they are statistically significant and have their expected signs. For example, more bedrooms and square footage are associated with house price increases. We also present the results of combining all stations together using a continuous distance measure instead of treatment distances in Appendix A7. The interaction term between Post and Mi. to Station is statistically insignificant in all models, though not very surprising given that this estimate is the average effect between Gold and Expo station areas.
} 
Table 2.3. Results: Houses Near Gold Stations

\begin{tabular}{|c|c|c|c|c|c|c|c|c|c|}
\hline & \multicolumn{3}{|c|}{ Model 1} & \multicolumn{3}{|c|}{ Model 2} & \multicolumn{3}{|c|}{ Model 3} \\
\hline & \multicolumn{3}{|c|}{$\begin{array}{l}\text { Pre-Groundbreak and Post- } \\
\text { Groundbreak/Pre-Open }\end{array}$} & \multicolumn{3}{|c|}{ Post-Groundbreak/Pre-Open and Post-Open } & \multicolumn{3}{|c|}{ Pre-Open and Post-Open } \\
\hline & $(\leq 0.25 \mathrm{mi})$. & $(\leq 0.5 \mathrm{mi})$. & $(\leq 0.75$ mi. $)$ & $(\leq 0.25 \mathrm{mi})$. & $(\leq 0.5 \mathrm{mi})$. & $(\leq 0.75$ mi. $)$ & $(\leq 0.25 \mathrm{mi})$. & $(\leq 0.5 \mathrm{mi})$. & $(\leq 0.75 \mathrm{mi})$. \\
\hline Post & $\begin{array}{c}0.127 * * * \\
(0.0104)\end{array}$ & $\begin{array}{c}0.129 * * * \\
(0.0110)\end{array}$ & $\begin{array}{c}0.145 * * * \\
(0.0119)\end{array}$ & $\begin{array}{c}-0.266 * * * \\
(0.0094)\end{array}$ & $\begin{array}{c}-0.262 * * * \\
(0.0099)\end{array}$ & $\begin{array}{c}-0.273 * * * \\
(0.0108)\end{array}$ & $\begin{array}{c}-0.0589 * * * \\
(0.0073)\end{array}$ & $\begin{array}{c}-0.0582 * * * \\
(0.0076)\end{array}$ & $\begin{array}{c}-0.0418^{* * *} \\
(0.0083)\end{array}$ \\
\hline Treated & $\begin{array}{c}-0.0906 \text { *** } \\
(0.0171)\end{array}$ & $\begin{array}{c}-0.189^{* * *} * \\
(0.0105)\end{array}$ & $\begin{array}{c}-0.114 * * * \\
(0.0096)\end{array}$ & $\begin{array}{c}-0.0474 * * * \\
(0.0103)\end{array}$ & $\begin{array}{c}-0.131^{* * *} \\
(0.0071)\end{array}$ & $\begin{array}{c}-0.0966^{* * *} \\
(0.0065)\end{array}$ & $\begin{array}{c}-0.0541^{* * *} \\
(0.0101)\end{array}$ & $\begin{array}{c}-0.133^{* * *} \\
(0.0065)\end{array}$ & $\begin{array}{c}-0.0962 * * * \\
(0.0060)\end{array}$ \\
\hline Post $\mathrm{x}$ Treated & $\begin{array}{l}0.0349 * \\
(0.0184)\end{array}$ & $\begin{array}{l}0.00831 \\
(0.0098)\end{array}$ & $\begin{array}{l}-0.00179 \\
(0.0088)\end{array}$ & $\begin{array}{c}0.0428^{* * *} * \\
(0.0165)\end{array}$ & $\begin{array}{c}0.0343 * * * \\
(0.0090)\end{array}$ & $\begin{array}{l}0.00724 \\
(0.0080)\end{array}$ & $\begin{array}{c}0.0398 * * * \\
(0.0120)\end{array}$ & $\begin{array}{c}0.0449 * * * \\
(0.0065)\end{array}$ & $\begin{array}{l}0.00931 \\
(0.0058)\end{array}$ \\
\hline House Characteristics & Yes & Yes & Yes & Yes & Yes & Yes & Yes & Yes & Yes \\
\hline School FE & Yes & Yes & Yes & Yes & Yes & Yes & Yes & Yes & Yes \\
\hline Year FE & Yes & Yes & Yes & Yes & Yes & Yes & Yes & Yes & Yes \\
\hline Station FE & Yes & Yes & Yes & Yes & Yes & Yes & Yes & Yes & Yes \\
\hline Observations & 28,880 & 26,887 & 26,153 & 33,378 & 31,408 & 30,947 & 57,661 & 54,009 & 52,909 \\
\hline R-squared & 0.693 & 0.692 & 0.678 & 0.724 & 0.717 & 0.712 & 0.737 & 0.734 & 0.726 \\
\hline $\begin{array}{c}\text { Adjusted R-squared } \\
\text { Standard errors in } \\
\text { parentheses } \\
* * * \mathrm{p}<0.01, * * \mathrm{p}<0.05, \\
* \mathrm{p}<0.1\end{array}$ & 0.691 & 0.69 & 0.676 & 0.723 & 0.715 & 0.711 & 0.737 & 0.733 & 0.725 \\
\hline
\end{tabular}


In Table 2.3, we find some evidence that the opening of the new Gold Line was positively capitalized into nearby house prices. The interaction term between Post and Treated is positive and statistically significant for close treatment distances in all models. For example, with a treatment distance of 0.25 miles in Model 1 , the results indicate that houses in close proximity to a station once construction started sold for $3.49 \%$ more. Using the mean house price for treated houses near Gold stations that were purchased post-groundbreak but still pre-open, this suggests that houses sold for approximately $\$ 9,539$ more. It appears that residents saw benefits of the line in the future. However, this effect becomes statistically insignificant with larger treatment distances, suggesting only those residents in very close proximity appeared to value the future benefit. There is also evidence that house prices increased once the line opened. For example, looking at Model 3, houses within 0.25 miles of a station sold for $3.98 \%$, or $\$ 13,338$, more than control houses. Overall, the results indicate that the new Gold Line was positively capitalized into houses in close proximity of the station, regardless if the house was sold during the construction phase or after it opened.

The results from only including houses in which the closest station is on the Expo Line are included in Table 2.4. While all of the interaction term estimates are statistically insignificant in Models 2 and 3, there does appear to be a negative anticipation effect for those houses that are very close to a station once construction started. Specifically, houses within 0.25 miles of an Expo station sold for approximately $5.62 \%$, or $\$ 12,689$, less once construction started. This suggests that residents negatively valued being in close proximity to the location of the stations post-groundbreak, perhaps because they knew they would be living next to construction sites until the line opened. However, once the anticipation effects decreased prices, no further price decreases happened. 
Table 2.4. Results: Houses Near Expo Stations

\begin{tabular}{|c|c|c|c|c|c|c|c|c|c|}
\hline & \multicolumn{3}{|c|}{$\begin{array}{c}\text { Model } 1 \\
\text { Pre-Groundhreak and Poct-Groundhreak/Pre }\end{array}$} & \multicolumn{3}{|c|}{ Model 2} & \multicolumn{3}{|c|}{ Model 3} \\
\hline & \multicolumn{3}{|c|}{$\begin{array}{l}\text { Pre-Groundbreak and Post-Groundbreak/Pre- } \\
\text { Open } \\
\end{array}$} & \multicolumn{3}{|c|}{ Post-Groundbreak/Pre-Open and Post-Open } & \multicolumn{3}{|c|}{ Pre-Open and Post-Open } \\
\hline & $(\leq 0.25 \mathrm{mi})$. & $(\leq 0.5$ mi. $)$ & $(\leq 0.75$ mi. $)$ & $(\leq 0.25$ mi. $)$ & $(\leq 0.5 \mathrm{mi})$. & $(\leq 0.75 \mathrm{mi})$. & $(\leq 0.25$ mi. $)$ & $(\leq 0.5 \mathrm{mi})$. & $(\leq 0.75 \mathrm{mi})$. \\
\hline Post & $\begin{array}{c}0.321 * * * \\
(0.0127)\end{array}$ & $\begin{array}{c}0.312 * * * \\
(0.0133)\end{array}$ & $\begin{array}{c}0.324 * * * \\
(0.0134)\end{array}$ & $\begin{array}{c}-0.283 * * * \\
(0.0159)\end{array}$ & $\begin{array}{c}-0.309 * * * \\
(0.0171)\end{array}$ & $\begin{array}{c}-0.312 * * * \\
(0.0179)\end{array}$ & $\begin{array}{c}0.659 * * * \\
(0.0156)\end{array}$ & $\begin{array}{c}0.637 * * * \\
(0.0168)\end{array}$ & $\begin{array}{c}0.651 * * * \\
(0.0173)\end{array}$ \\
\hline Treated & $\begin{array}{c}-0.116^{* * * *} \\
(0.0211)\end{array}$ & $\begin{array}{c}-0.124 * * * \\
(0.0123)\end{array}$ & $\begin{array}{c}-0.0723 * * * \\
(0.0110)\end{array}$ & $\begin{array}{c}-0.0732 * * \\
(0.0349)\end{array}$ & $\begin{array}{c}-0.102 * * * \\
(0.0207)\end{array}$ & $\begin{array}{c}-0.0424 * * \\
(0.0194)\end{array}$ & $\begin{array}{c}-0.0860^{* *} \\
(0.0346)\end{array}$ & $\begin{array}{c}-0.129 * * * \\
(0.0184)\end{array}$ & $\begin{array}{c}-0.0542 * * * \\
(0.0157)\end{array}$ \\
\hline Post $x$ Treated & $\begin{array}{c}-0.0562 * * \\
(0.0230)\end{array}$ & $\begin{array}{l}-0.00234 \\
(0.0117)\end{array}$ & $\begin{array}{c}0.000856 \\
(0.0098)\end{array}$ & $\begin{array}{c}0.0213 \\
(0.0389)\end{array}$ & $\begin{array}{l}0.00045 \\
(0.0198)\end{array}$ & $\begin{array}{c}0.0174 \\
(0.0166)\end{array}$ & $\begin{array}{l}-0.0214 \\
(0.0354)\end{array}$ & $\begin{array}{l}-0.0094 \\
(0.0180)\end{array}$ & $\begin{array}{c}0.0159 \\
(0.0148)\end{array}$ \\
\hline House Characteristics & Yes & Yes & Yes & Yes & Yes & Yes & Yes & Yes & Yes \\
\hline School FE & Yes & Yes & Yes & Yes & Yes & Yes & Yes & Yes & Yes \\
\hline Year FE & Yes & Yes & Yes & Yes & Yes & Yes & Yes & Yes & Yes \\
\hline Station FE & Yes & Yes & Yes & Yes & Yes & Yes & Yes & Yes & Yes \\
\hline Observations & 28,884 & 27,524 & 27,977 & 8,472 & 8,102 & 8,242 & 33,000 & 31,410 & 31,937 \\
\hline R-squared & 0.685 & 0.685 & 0.682 & 0.713 & 0.711 & 0.696 & 0.694 & 0.693 & 0.692 \\
\hline $\begin{array}{c}\text { Adjusted R-squared } \\
\text { Standard errors in } \\
\text { parentheses } \\
\text { *** }<<0.01, * * \mathrm{p}<0.05, \\
* \mathrm{p}<0.1 \\
\end{array}$ & 0.684 & 0.684 & 0.681 & 0.71 & 0.708 & 0.694 & 0.693 & 0.692 & 0.691 \\
\hline
\end{tabular}




\subsection{Sensitivity Analysis}

\subsection{1 - Robustness Check: Alternative Control Group}

To isolate the effect of living near the physical location of a station compared to living in close proximity to a line, we use an alternate set of control houses. Specifically, we used ArcGIS to identify houses that were close to the line, but not a station. For example, using a treatment distance of 0.25 miles, control houses must be further than 0.5 miles from a station, but within 0.25 miles of the line. Since living near a line but not a station may leave a resident with the cost of noise but not the benefits and costs of close proximity to the station, this analysis should provide further insight into the capitalization effect of living in close proximity to the stations.

Consistent with Table 2.3, the results for houses near Gold stations using the different control group in Table 2.5, suggest that for houses close to a station there is a positive capitalization effect. Specifically, house prices increased approximately 5-7\% in each stage of the process. This implies that it is the access to the station that is driving the positive capitalization effect.

Table 2.6 contains the results using our new set of control houses for houses near Expo stations. Like in Table 2.3, we get a negative capitalization effect, overall, but it is stronger. Perhaps this is because, unlike houses near the lines, there are additional negative externalities associated with proximity to stations (i.e. crime). 
Table 2.5. Alternative Control Group Results: Houses Near Gold Stations

\begin{tabular}{|c|c|c|c|c|c|c|c|c|c|}
\hline & \multicolumn{3}{|c|}{ Model 1} & \multicolumn{3}{|c|}{ Model 2} & \multicolumn{3}{|c|}{ Model 3} \\
\hline & \multicolumn{3}{|c|}{ Pre-Groundbreak and Post-Groundbreak/Pre-Open } & \multicolumn{3}{|c|}{ Post-Groundbreak/Pre-Open and Post-Open } & \multicolumn{3}{|c|}{ Pre-Open and Post-Open } \\
\hline & $(\leq 0.25 \mathrm{mi})$. & $(\leq 0.5 \mathrm{mi})$. & $(\leq 0.75 \mathrm{mi})$. & $(\leq 0.25 \mathrm{mi})$. & $(\leq 0.5$ mi. $)$ & $(\leq 0.75$ mi. $)$ & $(\leq 0.25 \mathrm{mi})$. & $(\leq 0.5 \mathrm{mi})$. & $(\leq 0.75 \mathrm{mi})$. \\
\hline Post & $\begin{array}{c}0.180 * * * \\
(0.0365)\end{array}$ & $\begin{array}{c}0.117 * * * \\
(0.0262)\end{array}$ & $\begin{array}{c}0.129 * * * \\
(0.0283)\end{array}$ & $\begin{array}{c}-0.397 * * * \\
(0.0352)\end{array}$ & $\begin{array}{c}-0.296 * * * \\
(0.0227)\end{array}$ & $\begin{array}{c}-0.279 * * * \\
(0.0237)\end{array}$ & $\begin{array}{c}-0.0862 * * * * \\
(0.0259)\end{array}$ & $\begin{array}{c}-0.0784 * * * \\
(0.0170)\end{array}$ & $\begin{array}{l}-0.0306^{*} \\
(0.0177)\end{array}$ \\
\hline Treated & $\begin{array}{c}-0.0523^{*} \\
(0.0304)\end{array}$ & $\begin{array}{c}-0.132 * * * \\
(0.0227)\end{array}$ & $\begin{array}{l}-0.0238 \\
(0.0256)\end{array}$ & $\begin{array}{c}0.017 \\
(0.0186)\end{array}$ & $\begin{array}{c}-0.0550^{* * * *} \\
(0.0148)\end{array}$ & $\begin{array}{c}-0.0395 * * * \\
(0.0151)\end{array}$ & $\begin{array}{l}-0.0174 \\
(0.0179)\end{array}$ & $\begin{array}{c}-0.0703 * * * \\
(0.0135)\end{array}$ & $\begin{array}{c}-0.0320^{* * *} \\
(0.0146)\end{array}$ \\
\hline Post x Treated & $\begin{array}{l}0.00587 \\
(0.0292)\end{array}$ & $\begin{array}{c}0.0719 * * * \\
(0.0213)\end{array}$ & $\begin{array}{c}0.0318 \\
(0.0261)\end{array}$ & $\begin{array}{c}0.0617 * * \\
(0.0242)\end{array}$ & $\begin{array}{c}0.0281 \\
(0.0178)\end{array}$ & $\begin{array}{l}-0.0145 \\
(0.0208)\end{array}$ & $\begin{array}{c}-0.00912 \\
(0.0177)\end{array}$ & $\begin{array}{c}0.0563^{* * *} \\
(0.0131)\end{array}$ & $\begin{array}{l}-0.00278 \\
(0.0156)\end{array}$ \\
\hline Constant & $\begin{array}{l}11.64 * * * \\
(0.0764)\end{array}$ & $\begin{array}{l}11.86 * * * \\
(0.1330)\end{array}$ & $\begin{array}{c}12.34 * * * \\
(0.0562)\end{array}$ & $\begin{array}{l}13.35^{* * * *} \\
(0.1850)\end{array}$ & $\begin{array}{c}12.22 * * * \\
(0.0649)\end{array}$ & $\begin{array}{l}12.25 * * * \\
(0.0404)\end{array}$ & $\begin{array}{c}13.46 * * * \\
(0.1760)\end{array}$ & $\begin{array}{l}12.07 * * * \\
(0.0607)\end{array}$ & $\begin{array}{l}12.20^{* * *} \\
(0.0343)\end{array}$ \\
\hline House Characteristics & Yes & Yes & Yes & Yes & Yes & Yes & Yes & Yes & Yes \\
\hline School FE & Yes & Yes & Yes & Yes & Yes & Yes & Yes & Yes & Yes \\
\hline Year FE & Yes & Yes & Yes & Yes & Yes & Yes & Yes & Yes & Yes \\
\hline Station FE & Yes & Yes & Yes & Yes & Yes & Yes & Yes & Yes & Yes \\
\hline Observations & 2,831 & 8,036 & 14,678 & 3,745 & 10,402 & 18,136 & 6,086 & 17,025 & 30,347 \\
\hline R-squared & 0.644 & 0.646 & 0.642 & 0.714 & 0.685 & 0.694 & 0.704 & 0.7 & 0.704 \\
\hline $\begin{array}{c}\text { Adjusted R-squared } \\
\text { Standard errors in } \\
\text { parentheses } \\
* * * \mathrm{p}<0.01, * * \\
\mathrm{p}<0.05, * \mathrm{p}<0.1\end{array}$ & 0.634 & 0.642 & 0.639 & 0.708 & 0.682 & 0.692 & 0.699 & 0.698 & 0.703 \\
\hline
\end{tabular}


Table 2.6. Alternative Control Group Results: Houses Near Expo Stations

\begin{tabular}{|c|c|c|c|c|c|c|c|c|c|}
\hline & \multirow{2}{*}{\multicolumn{3}{|c|}{$\begin{array}{l}\text { Model } 1 \\
\text { ak and Post-Groundbreak/Pre- } \\
\text { Open }\end{array}$}} & \multicolumn{3}{|c|}{ Model 2} & \multicolumn{3}{|c|}{ Model 3} \\
\hline & & & & \multicolumn{3}{|c|}{ Post-Groundbreak/Pre-Open and Post-Open } & \multicolumn{3}{|c|}{ Pre-Open and Post-Open } \\
\hline & $(\leq 0.25 \mathrm{mi})$. & $(\leq 0.5 \mathrm{mi})$. & $(\leq 0.75 \mathrm{mi})$. & $(\leq 0.25 \mathrm{mi})$. & $(\leq 0.5 \mathrm{mi})$. & $(\leq 0.75$ mi. $)$ & $(\leq 0.25$ mi. $)$ & $(\leq 0.5 \mathrm{mi})$. & $(\leq 0.75 \mathrm{mi})$. \\
\hline Post & $\begin{array}{l}0.397 * * * \\
(0.0368)\end{array}$ & $\begin{array}{l}0.429 * * * \\
(0.0269)\end{array}$ & $\begin{array}{l}0.449 * * * \\
(0.0248)\end{array}$ & $\begin{array}{c}-0.169 * * * \\
(0.0400)\end{array}$ & $\begin{array}{c}-0.251 * * * \\
(0.0347)\end{array}$ & $\begin{array}{c}-0.232 * * * \\
(0.0313)\end{array}$ & $\begin{array}{l}0.784 * * * \\
(0.0434)\end{array}$ & $\begin{array}{l}0.751 * * * \\
(0.0337)\end{array}$ & $\begin{array}{l}0.798 * * * \\
(0.0301)\end{array}$ \\
\hline Post $x$ Treated & $\begin{array}{c}-0.110^{* * *} \\
(0.0278)\end{array}$ & $\begin{array}{c}-0.0842^{* * *} \\
(0.0210)\end{array}$ & $\begin{array}{c}-0.125 * * * \\
(0.0209)\end{array}$ & $\begin{array}{l}-0.0313 \\
(0.0426)\end{array}$ & $\begin{array}{c}-0.038 \\
(0.0306)\end{array}$ & $\begin{array}{c}-0.0621 * * \\
(0.0288)\end{array}$ & $\begin{array}{c}-0.0830^{* *} \\
(0.0399)\end{array}$ & $\begin{array}{c}-0.0657 * * \\
(0.0279)\end{array}$ & $\begin{array}{c}-0.125^{* * *} \\
(0.0267)\end{array}$ \\
\hline Constant & $\begin{array}{l}11.34 * * * \\
(0.2470)\end{array}$ & $\begin{array}{l}12.13 * * * \\
(0.0682)\end{array}$ & $\begin{array}{l}11.11^{* * *} \\
(0.2040)\end{array}$ & $\begin{array}{l}12.73 * * * \\
(0.0388)\end{array}$ & $\begin{array}{l}13.18^{* * * *} \\
(0.1620)\end{array}$ & $\begin{array}{l}12.81 * * * \\
(0.1430)\end{array}$ & $\begin{array}{l}11.42 * * * \\
(0.2480)\end{array}$ & $\begin{array}{l}12.20 * * * \\
(0.0642)\end{array}$ & $\begin{array}{l}11.03 * * * \\
(0.2010)\end{array}$ \\
\hline House Characteristics & Yes & Yes & Yes & Yes & Yes & Yes & Yes & Yes & Yes \\
\hline School FE & Yes & Yes & Yes & Yes & Yes & Yes & Yes & Yes & Yes \\
\hline Year FE & Yes & Yes & Yes & Yes & Yes & Yes & Yes & Yes & Yes \\
\hline Station FE & Yes & Yes & Yes & Yes & Yes & Yes & Yes & Yes & Yes \\
\hline Observations & 3,213 & 8,224 & 14,870 & 1,199 & 2,674 & 4,565 & 3,793 & 9,475 & 17,081 \\
\hline R-squared & 0.714 & 0.731 & 0.688 & 0.707 & 0.722 & 0.693 & 0.717 & 0.733 & 0.699 \\
\hline $\begin{array}{c}\text { Adjusted R-squared } \\
\text { Standard errors in } \\
\text { parentheses } \\
* * * \mathrm{p}<0.01, * * \\
\mathrm{p}<0.05, * \mathrm{p}<0.1\end{array}$ & 0.71 & 0.729 & 0.687 & 0.698 & 0.717 & 0.69 & 0.713 & 0.732 & 0.698 \\
\hline
\end{tabular}




\subsection{2 - Quantile Regression}

Our main results provide evidence that the capitalization effect of metro rail access is different for the areas near the Gold and Expo Line stations. Additionally, as previously described, the demographics of the residents in these areas, as well as the characteristics of the houses are very different. Therefore, we use quantile regression to assess further how the capitalization effect differs based on different ranges of house prices, which act as a proxy for income levels.

We separate our sample into four different quantiles based on prices in the overall housing market. Specifically, we use the normalized house prices for all houses within 3 miles of any station in our study. We use this distance because it is more likely to be more representative of the overall housing market in the area, rather than only those houses very close to stations. This results in the following quantiles: under $\$ 170,000$ (below .25), $\$ 170,001-\$ 265,000$ (.25 to 0.50 ), $\$ 265,001$ - $\$ 410,000$ (.50 to 0.75 ), and above $\$ 410,001$ (above .75 ).

The results for the quantile analysis are contained in Table 2.7. In this analysis, we use the treatment distance of 0.5 miles and focus on the effect of the line opening (similar to Model 3 in the previous tables). ${ }^{29}$ Table 2.7 shows that there is a statistically significant and positive capitalization effect for houses near Gold stations in the lowest quantile, which suggests that lower income households are positively valuing the proximity to the stations. Thus, it appears that the positive capitalization effect represented in the main results for houses near Gold stations (Table 2.3) is being driven by the lower/middle income residents. Unlike the relatively wealthier

\footnotetext{
${ }^{29}$ We use a treatment distance of 0.5 miles to capture the effect of close proximity while also retaining a suitable number of transactions in each quantile. At closer distances, the number of observations per quantile is very small. The results using other treatment distances consistently show that lower income households positively value access. However, the results using other treatment distances provide some evidence that higher income households near Gold stations may negatively value living in close proximity to a station, further suggesting that the low/middle income communities are driving the positive capitalization effect found in our main results.
} 
homeowners, the lower/middle income residents in these communities may be more likely to use the lines to travel to downtown Los Angeles for their jobs and amenities. For example, a resident in this area (which is a relatively higher income area than the communities surrounding Expo Line stations) may have a job located downtown, but need the affordability of public transportation to justify living in the area.

For houses near the Expo Line stations, there is a positive and statistically significant price effect for the house in the highest quantile. However, there are much fewer higher valued properties near the Expo Line stations. For example, there were only 59 identifying observations in the highest quantile. Nonetheless, it appears that some residents throughout these very low income communities recognize the benefits of public transportation.

Table 2.7. Quantile Regression Results

Pre-Open and Post-Open $(\leq 0.5 \mathrm{mi}$.)

Below 25\% $\quad 25 \%-50 \% \quad 50 \%-75 \% \quad$ Above $75 \%$

Gold Stations

$\begin{array}{lllll}\text { Post x Treated } & 0.0219 * & 0.00291 & 0.00764 & -0.0255 \\ & (0.0132) & (0.00477) & (0.00522) & (0.0159)\end{array}$

Expo Stations

$\begin{array}{lllll}\text { Post } x \text { Treated } & 0.00882 & 0.00318 & -0.00603 & 0.0833 * *\end{array}$

$(0.0309) \quad(0.0104) \quad(0.0122) \quad(0.0336)$ 


\subsection{3 - Further Anticipation Analysis}

Our previous results indicate that house prices may have been impacted before the lines opened. To assess further how residents may have anticipated the opening, we use the "announcement" as the treatment year. Specifically, we use 1999 and 2003 as the treatment year for houses near Gold stations and Expo stations, respectively. This timeframe should capture the effect from the formation of the Metro Gold Line and Expo Line Construction Authorities and the "announcement" of the lines, rather than simply the start of construction.

Table 2.8 contains the "announcement" results for houses near Gold stations. Model 1 compares those housing transactions before the "announcement", compared to those after the "announcement" but before the station opened. Model 2 includes all transactions in the sample, where the treatment is the "announcement" of the line. Model 3, which is a combination of Models 1 and 2, includes both the "announcement" and opening. ${ }^{30}$ By combining these models, we can better determine the timing of the effects, as well as the overall impact.

Consistent with the parallel trends plot, the results in Model 1 suggest that there was a decrease in house prices once the "announcement" was made. However, this is only for the 0.75 mile treatment distance. Perhaps at this distance, homeowners did not expect to benefit from the close proximity to the station, but instead to only be negatively impacted by the externalities of congestion. However, when all house transactions sold post-“announcement" are included in Model 2, we find a positive and statistically significant difference-in-differences result using a 0.5 mile treatment distance. When we look at Model 3, we find no statistically significant difference-in-difference results for the "announcement" and positive and statistically significant

\footnotetext{
${ }^{30}$ In Model 3, the identifying observations are the treated houses sold post-“announcement but still pre-open and those sold post-open. Therefore, we do not have any double counting of the Post $x$ Treated groups.
} 
results for the opening. It appears there were no "announcement" effects for house prices near Gold stations and house prices did not increase until after the line opened.

The "announcement" results for houses near Expo stations are presented in Table 2.9. There is some evidence that residents purchasing homes near Expo stations positively valued being in close proximity to the stations after the "announcement" was made. For example, house prices increased approximately $3 \%$ once the "announcement" was made (using a treatment distance of 0.5 miles in Model 1). Unlike the "announcement" results for houses near Gold stations, the results in Model 3 indicate that the "announcement" generated positive capitalization effects. Since the Expo stations were "announced" after the first phase of the Gold stations opened, perhaps this positive "announcement" effect is from residents recognizing the positive benefits that the areas near the new Gold Line experienced, and anticipating to receive the same. Consistent with our main results (Table 2.4), we also find that there was no capitalization effect once the Expo stations opened. Overall, these results suggest that residents reacted as soon as the "announcement" was made and the market adjusted well in advance of the actual opening. 
Table 2.8. "Announcement" Results: Houses Near Gold Stations

\begin{tabular}{|c|c|c|c|c|c|c|c|c|c|}
\hline & \multicolumn{3}{|c|}{ Model 1} & \multicolumn{3}{|c|}{ Model 2} & \multicolumn{3}{|c|}{ Model 3} \\
\hline & \multicolumn{3}{|c|}{$\begin{array}{l}\text { Pre-"Announcement" and Post- } \\
\text { "Announcement"/Pre-Open } \\
\end{array}$} & \multicolumn{3}{|c|}{$\begin{array}{l}\text { Pre-"Announcement" and Post- } \\
\text { "Announcement" }\end{array}$} & \multicolumn{3}{|c|}{$\begin{array}{l}\text { Pre-"Announcement" and Post-"Announcement"/Pre- } \\
\text { Open and Pre-Open and Post-Open }\end{array}$} \\
\hline & $(\leq 0.25$ mi. $)$ & $(\leq 0.5 \mathrm{mi})$. & $(\leq 0.75 \mathrm{mi})$. & $(\leq 0.25 \mathrm{mi})$. & $(\leq 0.5 \mathrm{mi})$. & $(\leq 0.75 \mathrm{mi})$. & $(\leq 0.25 \mathrm{mi})$. & $(\leq 0.5 \mathrm{mi})$. & $(\leq 0.75 \mathrm{mi})$. \\
\hline Post-"Announcement" & $\begin{array}{l}0.482 * * * \\
(0.0194)\end{array}$ & $\begin{array}{l}0.498 * * * \\
(0.0196)\end{array}$ & $\begin{array}{l}0.497 * * * \\
(0.0218)\end{array}$ & $\begin{array}{l}0.640 * * * \\
(0.0112)\end{array}$ & $\begin{array}{c}0.646 * * * \\
(0.0118)\end{array}$ & $\begin{array}{l}0.653 * * * \\
(0.0123)\end{array}$ & $\begin{array}{l}0.676 * * * \\
(0.0132)\end{array}$ & $\begin{array}{l}0.678 * * * \\
(0.0138)\end{array}$ & $\begin{array}{l}0.673 * * * \\
(0.0145)\end{array}$ \\
\hline Treated & $\begin{array}{c}-0.107 * * * \\
(0.0152)\end{array}$ & $\begin{array}{l}-0.191 * * * \\
(0.00967)\end{array}$ & $\begin{array}{l}-0.112 * * * \\
(0.00863)\end{array}$ & $\begin{array}{c}-0.0905 * * * \\
(0.0142)\end{array}$ & $\begin{array}{l}-0.175^{* * * *} \\
(0.00830)\end{array}$ & $\begin{array}{c}-0.0992 * * * \\
(0.00733)\end{array}$ & $\begin{array}{c}-0.0902 * * * \\
(0.0142)\end{array}$ & $\begin{array}{l}-0.176 * * * \\
(0.00829)\end{array}$ & $\begin{array}{c}-0.0993 * * * \\
(0.00733)\end{array}$ \\
\hline $\begin{array}{l}\text { Post-"Announcement" } \\
\text { x Treated }\end{array}$ & $\begin{array}{c}0.0116 \\
(0.0172)\end{array}$ & $\begin{array}{l}-0.00227 \\
(0.00929)\end{array}$ & $\begin{array}{l}-0.0143 * \\
(0.00828)\end{array}$ & $\begin{array}{c}0.0204 \\
(0.0148)\end{array}$ & $\begin{array}{l}0.0262 * * * \\
(0.00778)\end{array}$ & $\begin{array}{l}-0.00383 \\
(0.00682)\end{array}$ & $\begin{array}{l}-0.00252 \\
(0.0163)\end{array}$ & $\begin{array}{c}0.00281 \\
(0.00876)\end{array}$ & $\begin{array}{l}-0.0133 * \\
(0.00773)\end{array}$ \\
\hline Post-Open & & & & & & & $\begin{array}{c}-0.0366 * * * \\
(0.00686)\end{array}$ & $\begin{array}{c}-0.0370 * * * \\
(0.00728)\end{array}$ & $\begin{array}{c}-0.0240 * * * \\
(0.00807)\end{array}$ \\
\hline Post-Open x Treated & & & & & & & $\begin{array}{c}0.0407 * * * \\
(0.0131)\end{array}$ & $\begin{array}{c}0.0416^{* * *} \\
(0.00727)\end{array}$ & $\begin{array}{l}0.0167 * * \\
(0.00653)\end{array}$ \\
\hline Constant & $\begin{array}{l}12.20 * * * \\
(0.0347)\end{array}$ & $\begin{array}{l}12.21 * * * \\
(0.0365)\end{array}$ & $\begin{array}{l}12.29 * * * \\
(0.0358)\end{array}$ & $\begin{array}{l}12.08 * * * \\
(0.0239)\end{array}$ & $\begin{array}{l}12.09 * * * \\
(0.0244)\end{array}$ & $\begin{array}{l}12.18 * * * \\
(0.0242)\end{array}$ & $\begin{array}{l}12.08 * * * \\
(0.0239)\end{array}$ & $\begin{array}{l}12.10^{* * * *} \\
(0.0244)\end{array}$ & $\begin{array}{l}12.18 * * * \\
(0.0242)\end{array}$ \\
\hline House Characteristics & Yes & Yes & Yes & Yes & Yes & Yes & Yes & Yes & Yes \\
\hline School FE & Yes & Yes & Yes & Yes & Yes & Yes & Yes & Yes & Yes \\
\hline Year FE & Yes & Yes & Yes & Yes & Yes & Yes & Yes & Yes & Yes \\
\hline Station FE & Yes & Yes & Yes & Yes & Yes & Yes & Yes & Yes & Yes \\
\hline Observations & 28,734 & 26,753 & 26,062 & 57,054 & 53,444 & 52,381 & 57,054 & 53,444 & 52,381 \\
\hline R-squared & 0.689 & 0.691 & 0.673 & 0.736 & 0.732 & 0.724 & 0.736 & 0.732 & 0.724 \\
\hline $\begin{array}{c}\text { Adjusted R-squared } \\
\text { Standard errors in } \\
\text { parentheses } \\
* * * \mathrm{p}<0.01, * * \\
\mathrm{p}<0.05, * \mathrm{p}<0.1 \\
\end{array}$ & 0.687 & 0.689 & 0.671 & 0.735 & 0.731 & 0.723 & 0.735 & 0.731 & 0.723 \\
\hline
\end{tabular}


Table 2.9. "Announcement" Results: Houses Near Expo Stations

\begin{tabular}{|c|c|c|c|c|c|c|c|c|c|}
\hline & \multicolumn{3}{|c|}{ Model 1} & \multicolumn{3}{|c|}{ Model 2} & \multicolumn{3}{|c|}{ Model 3} \\
\hline & \multicolumn{3}{|c|}{$\begin{array}{l}\text { Pre-"Announcement" and Post- } \\
\text { "Announcement"/Pre-Open }\end{array}$} & \multicolumn{3}{|c|}{$\begin{array}{l}\text { Pre-"Announcement" and Post- } \\
\text { "Announcement" }\end{array}$} & \multicolumn{3}{|c|}{$\begin{array}{l}\text { Pre-"Announcement" and Post- } \\
\text { "Announcement"/Pre-Open and Pre-Open and } \\
\text { Post-Open }\end{array}$} \\
\hline & $(\leq 0.25 \mathrm{mi})$. & $(\leq 0.5 \mathrm{mi})$. & $(\leq 0.75 \mathrm{mi})$. & $(\leq 0.25 \mathrm{mi})$. & $(\leq 0.5 \mathrm{mi})$. & $(\leq 0.75 \mathrm{mi})$. & $(\leq 0.25 \mathrm{mi})$. & $(\leq 0.5 \mathrm{mi})$. & $(\leq 0.75 \mathrm{mi})$. \\
\hline Post-"Announcement" & $\begin{array}{l}0.313 * * * \\
(0.0126)\end{array}$ & $\begin{array}{l}0.299 * * * \\
(0.0132)\end{array}$ & $\begin{array}{l}0.311 * * * \\
(0.0131)\end{array}$ & $\begin{array}{l}0.657 * * * \\
(0.0157)\end{array}$ & $\begin{array}{c}0.627 * * * \\
(0.0166)\end{array}$ & $\begin{array}{l}0.647 * * * \\
(0.0164)\end{array}$ & $\begin{array}{l}0.345^{* * * *} \\
(0.0127)\end{array}$ & $\begin{array}{c}0.333 * * * \\
(0.0132)\end{array}$ & $\begin{array}{l}0.346^{* * *} \\
(0.0133)\end{array}$ \\
\hline Treated & $\begin{array}{c}-0.0735^{* * * *} \\
(0.0141)\end{array}$ & $\begin{array}{l}-0.133 * * * \\
(0.00917)\end{array}$ & $\begin{array}{l}-0.0827 * * * \\
(0.00849)\end{array}$ & $\begin{array}{c}-0.0717 * * * \\
(0.0142)\end{array}$ & $\begin{array}{l}-0.133 * * * \\
(0.00899)\end{array}$ & $\begin{array}{l}-0.0820 * * * \\
(0.00832)\end{array}$ & $\begin{array}{c}-0.0716^{* * * *} \\
(0.0142)\end{array}$ & $\begin{array}{l}-0.133 * * * \\
(0.00899)\end{array}$ & $\begin{array}{c}-0.0819 * * * \\
(0.00832)\end{array}$ \\
\hline $\begin{array}{l}\text { Post-"Announcement" } \\
\text { x Treated }\end{array}$ & $\begin{array}{l}0.00908 \\
(0.0190)\end{array}$ & $\begin{array}{l}0.0301 * * * \\
(0.00976)\end{array}$ & $\begin{array}{l}0.0201 * * \\
(0.00812)\end{array}$ & $\begin{array}{l}0.00225 \\
(0.0181)\end{array}$ & $\begin{array}{c}0.0255^{* * *} * \\
(0.00921)\end{array}$ & $\begin{array}{l}0.0196 * * \\
(0.00767)\end{array}$ & $\begin{array}{l}0.00450 \\
(0.0187)\end{array}$ & $\begin{array}{c}0.0284 * * * \\
(0.00956)\end{array}$ & $\begin{array}{l}0.0182 * * \\
(0.00796)\end{array}$ \\
\hline Post-Open & & & & & & & $\begin{array}{c}0.312 * * * \\
(0.0154)\end{array}$ & $\begin{array}{c}0.298 * * * \\
(0.0165)\end{array}$ & $\begin{array}{c}0.297 * * * \\
(0.0172)\end{array}$ \\
\hline Post-Open x Treated & & & & & & & $\begin{array}{l}-0.0174 \\
(0.0370)\end{array}$ & $\begin{array}{l}-0.0209 \\
(0.0188)\end{array}$ & $\begin{array}{c}0.0103 \\
(0.0156)\end{array}$ \\
\hline Constant & $\begin{array}{c}10.80 * * * \\
(0.241)\end{array}$ & $\begin{array}{c}10.79 * * * \\
(0.243)\end{array}$ & $\begin{array}{c}10.77 * * * \\
(0.238)\end{array}$ & $\begin{array}{c}10.75^{* * * *} \\
(0.243)\end{array}$ & $\begin{array}{c}10.74 * * * \\
(0.245)\end{array}$ & $\begin{array}{c}10.72 * * * \\
(0.241)\end{array}$ & $\begin{array}{l}12.08 * * * \\
(0.0239)\end{array}$ & $\begin{array}{c}12.10^{* * * *} \\
(0.0244)\end{array}$ & $\begin{array}{l}12.18^{* * * *} \\
(0.0242)\end{array}$ \\
\hline House Characteristics & Yes & Yes & Yes & Yes & Yes & Yes & Yes & Yes & Yes \\
\hline School FE & Yes & Yes & Yes & Yes & Yes & Yes & Yes & Yes & Yes \\
\hline Year FE & Yes & Yes & Yes & Yes & Yes & Yes & Yes & Yes & Yes \\
\hline Station FE & Yes & Yes & Yes & Yes & Yes & Yes & Yes & Yes & Yes \\
\hline Observations & 28,601 & 27,219 & 27,722 & 32,451 & 30,920 & 31,402 & 57,054 & 53,444 & 52,381 \\
\hline R-squared & 0.700 & 0.701 & 0.701 & 0.694 & 0.694 & 0.692 & 0.736 & 0.732 & 0.724 \\
\hline $\begin{array}{l}\text { Adjusted R-squared } \\
\text { Standard errors in } \\
\text { parentheses } \\
\text { *** }<<0.01, * * \mathrm{p}<0.05 \\
* \mathrm{p}<0.1\end{array}$ & 0.700 & 0.700 & 0.700 & 0.693 & 0.693 & 0.691 & 0.735 & 0.731 & 0.723 \\
\hline
\end{tabular}




\subsection{Conclusion}

In our analysis, we examine the impact of the Gold and Expo metro lines on property values in Los Angeles. When we examine houses only near Gold Line stations, we find a positive capitalization effect after the stations opened. Our results suggest that on average, all houses in closer proximity to the stations sold for more and that the increase in house prices is primarily driven by the lower/middle income residents.

When examining only those houses near Expo Line stations, the results are a bit more mixed. However, one key takeaway is that these residents appear to be anticipating the opening. Perhaps this is because of the potential retail and commercial benefits that are also associated with new metro lines. For example, people may be willing to pay more for a house that is close to the location of a future station if it is expected that the new line will also spark commercial or retail developments from which residents can benefit (or if the new retail developments open prior to the line). Our findings suggest that the market adjusted well in advance of the actual opening, with little additional impact after the line opened. Therefore, it is important to consider the effects that may be occurring before a station opens when determining the impact on a community.

Overall, our results provide evidence that the value residents place on metro rail access varies differs based on their income levels and other demographics. This is especially important for the future success of rail development. For example, we find some evidence of a positive capitalization effect, particularly in lower/middle income communities. Residents in these communities may be more likely to use public transportation to travel to their jobs, which may be in downtown Los Angeles. According to the Los Angeles County Metropolitan 
Transportation Authority, 67 percent of all fiscal year 2019 Gold Line boardings by station were headed to downtown Los Angeles (towards Union Station).

At the same time, residents in very low income areas may not have a job downtown, but still rely on the affordability of a metro line for transportation, as it may be cheaper than driving. The Los Angeles County Metropolitan Transportation Authority reported that only 47 percent of the fiscal year 2019 Expo Line boardings by station were headed to downtown Los Angeles. However, the Expo Line currently also extends all the way to Santa Monica (displayed in Figure 2.1), providing access to both the jobs and amenities in that community as well as to other communities along the way. Perhaps this connectivity is one reason why the results for houses near Expo stations are less clear.

Metro lines are becoming a very popular method of public transportation in many major cities. When planning for future metro rail development, our results suggest that it may be beneficial to consider where the lines lead in addition to the population along where they are located. For example, it may be the case that public transportation infrastructure may lead to positive capitalization effects if the line leads to desirable areas (especially for commuting purposes), or if stations are located in communities that need cheap, accessible transportation. With metro lines requiring large financial investments, it is important to understand how residents in different communities value increased access. Our analysis not only provides insight into how residents in Los Angeles value metro access, but also how residents in other large cities may value it. 


\section{Chapter 3}

\section{The Amenity Value of Sports Facilities: Evidence from the Staples Center in Los Angeles}

\subsection{Introduction}

The United States has experienced a boom in professional sports facility construction over the past two decades. Fifty-seven new stadiums and arenas for professional baseball, basketball, football, and hockey teams were built from 2000 to 2020 (Drukker et al., 2020) and many more new facilities will likely open over the next 15 years (Humphreys, 2019). Proponents of these construction projects claim that new sports facilities provide many benefits to local residents, including income increases, job creation, and tax revenue increases (Humphreys and Zhou, 2015; Matheson, 2019).

Critics consistently point out that these claims, most of which come from economic impact studies conducted by consulting firms, are flawed and are based on unrealistic assumptions about multiplier effects, neglect opportunity costs, and underestimate the substitution effects (Humphreys, 2019). In fact, several econometric studies have found that sports facilities generated little to no, or even negative, tangible economic impacts in the local economy (Coates, 2007; Coates and Humphreys, 2003).

Recent evidence shows that games played in new sports facilities generate significant local urban congestion externalities like increased crime (Montolio and Planells-Struse, 2016; Pyun, 2019), traffic (Humphreys and Pyun, 2018), and pollution (Locke, 2019), as well as declines in the response time of police to emergency calls (Propheter, 2019a). However, sports facilities can also generate positive local externalities through aesthetic elements like architectural appearance (Ahlfeldt and Kavetsos, 2014) or through access to consumption 
opportunities that cluster around sports facilities (Humphreys and Zhou, 2015). In general, this literature shows that negative and positive externalities generated by sports facilities may be capitalized into nearby property values. Chikish et al. (2019a) contains a recent survey of the literature on the impact of professional sports facilities on local residential property values.

The Staples Center in downtown Los Angeles, California, represents one sports facility for which the value to local/nearby residents has not been established. The Staples Center opened in 1999 and is the most intensely utilized professional sports venue in the United States (Chikish et al., 2019b). The arena is home to multiple professional sports teams, including the Los Angeles Lakers and Clippers of the National Basketball Association (NBA), the Los Angeles Kings of the National Hockey League (NHL), and the Los Angeles Sparks of the Women's National Basketball Association (WNBA). Additionally, it hosts numerous concerts and other events. Between four professional sports teams (with approximately 141 games a year, not including playoffs), concerts, and other events, the Staples Center is used by thousands of people almost every day throughout the entire year. This intense use suggests that it could generate substantial local congestion externalities that other related studies were not able to consider.

The arena was privately financed and cost $\$ 375$ million to build; equivalent to approximately $\$ 580$ million in 2020 dollars. The complex contains approximately 950,000 square feet of event space and can seat up to roughly 20,000 people. The opening of the Staples Center also sparked other subsequent local development, such as the adjacent L.A. Live entertainment complex and renovations to the Los Angeles Convention Center.

This paper contributes to the empirical literature on sports facilities and housing prices by analyzing transactions price data from a novel setting, the opening of the Staples Center in Los Angeles, a highly utilized sports facility. Using data from before and after the new arena 
announcement and opening, we estimate hedonic spatial difference-in-differences models to assess how the presence of the Staples Center affects nearby house prices. Nearby house prices increase if residents value living in close proximity to a sports facility and the amenities generated by the facility; or decrease in the presence of associated negative externalities or disamenities.

Most related research using hedonic spatial difference-in-differences models focused on proximity to one or two specific new facilities in a single city hosting a single team. For example, Tu (2005), Dehring et al. (2007), Kavetsos (2012), Ahlfeldt and Kavetsos, (2014), Humphreys and Nowak (2017), and Chikish et al. (2019a) all focused on estimating the impact of a new facility home to a single team or event on nearby property values. Negative and positive local externalities likely increase with intensity of use. The focus on single teams in the previous literature sheds limited light on the impact of intensity of facility use on net local externalities. While other studies have examined the impact of multi-purpose arenas, such as Brooklyn's Barclays Center (Propheter, 2019b), they have mostly focused on commercial land rents. Our study on the capitalization effect of the intensely utilized Staples Center into residential property values addresses these issues.

In addition, we contribute to the literature in several other important ways. We control for important local factors that previous research generally ignored, such as local school quality and access to highways. Relatively few related hedonic housing price papers control for these local amenities, which have been shown to impact house prices (Black, 1999; Boarnet and Chalermpong, 2011; Hou, 2017).

We test for the presence of "anticipation" effects associated with the announcement of the new arena location and local government approval, extending the literature on this topic. 
Previous evidence of "anticipation" effects came only from the awarding of the 2012 Summer Olympic Games to London (Kavetsos, 2012) and the announcement of proposed stadium locations in Dallas, Texas (Dehring et al., 2007).

We also use local polynomial regression (LPR), which is a spatial innovation employed in Linden and Rockoff (2008) and Diao et al. (2017), to verify our choice of spatial treatment zones. Most prior research used ad hoc treatment zones when using the hedonic spatial difference-in-differences method. LPR fits housing prices on distances to the arena with a locally-weighted least squares estimator and allows for non-linear capitalization effects. The graphical evidence from the LPR provides support for our selection of the treatment distances that we use in our difference-in-differences analysis.

The evidence developed in this paper shows that both the announcement of the location of the Staples Center and its opening generated positive externalities subsequently capitalized into local residential property values. Specifically, we find that houses in close proximity to the arena and with transactions after the arena opened sold for approximately 5-6\% more than those transacted before opening. We also find evidence of substantial and positive "anticipation" effects. In our case, house prices increased after the arena deal was announced relative to before the announcement. We also show that positive estimates of the impact of proximity to new sports facilities remain robust to controls for other local amenities known to increase house prices like the quality of local schools and other amenities like access to highways, as well as the different treatment distances identified by the LPR. Overall, our results provide evidence that privatelyfunded sports and entertainment facilities may have a net-positive spillover effect on the surrounding urban neighborhood. 


\subsection{Existing Literature}

In addition to the established literature assessing tangible economic benefits generated by new sports facilities, scholars increasingly turn to estimation of the value of intangible benefits; for example, how proximity to a sports facility impacts local house prices. One method for doing so uses hedonic spatial difference-in-differences models to assess the willingness to pay for local characteristics. Assessing the extent to which the opening of a new sports facility gets capitalized into nearby house prices can provide insight into how local residents value proximity to the facility and other local externalities generated by the facility. A growing literature takes this approach.

The first research to assess the intangible benefits generated by a new sports facility, $\mathrm{Tu}$ (2005), examined how proximity to the newly built FedEx Field in Landover, Maryland, impacted house prices within 2.5 miles of the facility. Using a hedonic spatial difference-indifferences approach, he found that properties near the stadium sold at a discount before the stadium opening, but the price differential narrowed after the opening. Tu (2005) controlled for house characteristics and census tract economic and demographic characteristics like median income and the percentage minority residents but did not control for factors like local school quality or access to other locational amenities like highways.

Ahlfeldt and Maennig $(2009,2010)$ provided evidence that two new Olympic quality sports facilities built in the 1990s, a velodrome and a multi-purpose arena, generated significant positive impacts on undeveloped land values within a 3,000-meter radius in Berlin, Germany. Estimated impacts on nearby land values from hedonic spatial difference-in-differences models ranged from $+1.3 \%$ to $+8 \%$ depending on model specification. Ahlfeldt and Maennig (2009) only controlled for distance to the facilities and various spatial and temporal fixed effects; while 
Ahlfeldt and Maennig (2010) estimated a richer model containing a number of neighborhood characteristics along with a spatial lag model, and generally reported larger positive impacts.

Ahlfeldt and Kavetsos (2014) analyzed the impact of the opening of two new stadiums in London, England, in the 2000s using a hedonic spatial difference-in-differences model and found positive effects on transacted house prices within 3 miles after the opening of both the New Wembly Stadium and the Emirates Stadium. They reported substantial effects, about $+15 \%$, near New Wembly that declined with distance, and smaller effects near Emirates. The models estimated by Ahlfeldt and Kavetsos (2014) contained rich time and distance varying effects of the new stadiums along with control variables for neighborhood characteristics including access to public transit. The models also accounted for the architecture and visual appearance of the new stadiums and generated evidence of a positive willingness to pay for these features.

Humphreys and Nowak (2017) analyzed the departure of two NBA teams from Seattle, Washington, and Charlotte, North Carolina, and found that both team departures generated increases in residential property prices near the arenas where the teams had played, suggesting that the teams generated local disamenities in these markets. They reported impacts of about $+7 \%$ in Seattle and $+10 \%$ in Charlotte within 1 to 2 miles of the facilities based on both hedonic spatial difference-in-differences models and repeat sales models.

Chikish et al. (2019a) analyzed the opening of a new NBA-caliber arena without an NBA team playing in the arena, and the later arrival of an NBA team, on nearby residential property prices in Oklahoma City, Oklahoma, using both hedonic spatial difference-in-differences models and repeat sales models. This represents an interesting case compared to other research focused on the construction of new facilities for existing teams, as they effectively estimated a gross new facility and existing team impact. The paper reported evidence that both the opening of the new 
arena and the later arrival of the new team generated increases in nearby residential property prices within 2 to 5 miles of the arena of between $+3 \%$ and $+6 \%$.

Another line of work in this literature analyzes "anticipation effects" generated by announcements about the future construction of a new sports facility on current house prices. Analyzing announcement effects on property values provides important insights into the impact of information in real estate markets, since at the time of the announcement of a proposed new sports facility no construction activity or sports events exist. The first paper on this topic, Dehring et al. (2007), reported evidence that house prices near proposed locations of a new professional football stadium in suburban Dallas, Texas, decreased following two separate announcements about the proposed locations of the new stadium. Dehring et al. (2007) found a $1.5 \%$ decrease in house prices in the same tax jurisdictions as the proposed stadium at the time of the announcements.

Kavetsos (2012) exploited the announcement of the awarding of the 2012 Summer Olympic Games to London, England, to estimate the effect of proposed new sports facility construction projects on residential house prices in London, using hedonic spatial difference-indifferences models. The International Olympic Committee awards the rights to host the Olympic Games through a vote, the winner cannot be known until the vote occurs, and bids submitted by potential host cities contain details about the substantial new sports facility construction projects that will be undertaken if a city's bid succeeds. This setting generated a clear informational shock exploited by Kavetsos (2012).

Kavetsos (2012) reported increases in residential property values of between $+2 \%$ and $+5 \%$ following the awarding of the 2012 Games to London depending on model specification. Ahlfeldt and Kavetsos (2014) developed further suggestive evidence that anticipatory effects of 
proposed new sports facilities impact current house prices but lacked a clean information shock to exploit.

Other papers analyze the impact of new sports facilities on different outcomes related to real estate markets and use methods other than hedonic spatial difference-in-differences. Feng and Humphreys (2012) found evidence of higher residential housing prices near existing processional sports facilities. Using data from construction of 56 new professional sports facilities, Huang and Humphreys (2014) found that the opening of a facility increased residential mortgage applications in the local area, which may reflect increased demand for residential property. Past research also found evidence of positive effects of sports facilities (Carlino and Coulson, 2004; Agha and Coates, 2015) and sports mega-events (Coates and Matheson, 2011) on rents. Feng and Humphreys (2018) estimated the impact of proximity to two existing sports facilities in Columbus, Ohio, on property values and found a significant, positive, and distance decaying effect using spatial lag models. Using a panel study of sixteen minor league baseball stadiums throughout the United States, van Holm (2019) found that new stadiums can lead to increases in median home prices and housing construction, but can also concentrate redevelopment rather than create growth.

In addition to sports facilities, previous research has also addressed the valuation of other types of entertainment-focused urban development. For example, Huang et al. (2016) found that new casinos in Canada have negative effects on the growth of housing values and rent. However, private service entertainment amenities have been shown to increase house prices in Shanghai, China (Li et al., 2019).

Overall, the literature contains mixed results. While many studies contain evidence that sports facilities generate positive local amenities which are positively capitalized into house 
prices, others contain evidence supporting the generation of local disamenities, based on both team departures (Humphreys and Nowak, 2017) and announcement effects (Dehring et al., 2007). Also, this literature using hedonic spatial difference-in-differences models primarily contains case studies focusing on one or two sports facilities or events in both Europe and the United States. Thus, an analysis of a novel setting can make an important contribution to the literature when much of the existing evidence consists of case studies.

\subsection{Econometric Methods}

Economists commonly use hedonic price models to assess the capitalization of nonmarket amenities or disamenities into house prices (Rosen, 1974). This model disaggregates observable attributes of a house and reveals the marginal willingness to pay for each specific attribute (Taylor, 2003). A hedonic price model will allow us to assess how observable dwelling attributes like number of bedrooms, square footage, age, etc., as well as local characteristics like proximity to a sports facility, impact house prices.

To assess how the opening of the Staples Center impacted nearby property values, we utilize a hedonic spatial difference-in-differences framework, a method used extensively in the literature estimating the impact of new sports facilities on property values (i.e., Tu, 2005; Dehring et al., 2007; Alfeldt and Maenning, 2009; Alfeldt and Maenning, 2010; Kavetsos, 2012; Ahlfeldt and Kavetsos, 2014, Humphreys and Nowak, 2017). This approach helps minimize the potential bias in estimating the impacts of locational amenities and disamenities generated by sports facilities (Ahlfeldt and Kavetsos, 2012). Specifically, we estimate the following hedonic model:

$$
\log (\text { Price })_{i t}=\beta_{0}+\beta_{1} \text { Post }+\beta_{2} \text { Treated }+\beta_{3}(\text { Post } x \text { Treated })+\beta_{4} H_{i t}+\beta_{5} \omega_{i t}+\theta_{j}+\eta_{t}+\varepsilon_{i j t}
$$


where $\log (\text { Price })_{i t}$ is the natural $\log$ of the normalized price of house $i$ in time $t$, and the vector $H_{i t}$ contains observable dwelling attributes (bedrooms, square feet, age, age squared, and a new construction dummy variable). We use the natural log of the transaction price to address theoretical concerns with using linear pricing (Rosen, 1974), to minimize the influence of outliers, and so that factors result in percent changes in the price. For example, while the addition of a new bedroom would likely increase the price of houses by about the same percent, we would not expect an additional bedroom to increase the price of a $\$ 200,000$ house by the same dollar amount as a $\$ 1.2$ million house.

Our model also includes a number of control variables that many of the previous related studies have omitted. For example, the variable $\omega_{i t}$ reflects other locational characteristics, such as distances to the closest highway, open metro rail station, and the University of Southern California (USC), the only large university in the area of analysis, which would all be expected to affect housing prices. Indicator variables for elementary school attendance zones, $\theta_{j}$, are also included to control for heterogeneity in local school quality since school quality has been found to be an important determinant of house prices (Black, 1999). Elementary school attendance zone indicator variables should also help control for any unobservable time-invariant spatial factors affecting house prices. The attendance zones are relatively small and houses that are close to each other may be in different zones. Also included is an indicator variable for the year the house was sold, $\eta_{t}$, to address any unobservable temporal heterogeneity.

The variable Post indicates houses transacted after the Staples Center opened. To ensure that Post partitions the sample into houses sold before and after the arena opened, houses sold in the same year the arena opened are excluded from the sample. Additionally, since house prices 
may increase or decrease after a future amenity/disamenity generating event is announced (McMillen and McDonald, 2004; Dehring et al., 2007; Kavetsos, 2012), we also assess whether residents "anticipated" the opening by examining the capitalization effect before the arena opened and either before or after the new arena location was announced. The exact location where the Staples Center would be built was announced in 1997 following a vote by the Los Angeles City Council (Plaschke, 1997), so for our anticipation analysis, we consider houses sold after 1997 as occurring Post arena announcement, and exclude sales from 1997 in those models.

A house is considered Treated if it is located within a certain treatment distance from the arena site. To support our selection of treatment distances, we use graphical evidence from a local polynomial regression (LPR) following the approach outlined in Diao et al. (2017). ${ }^{31}$ LPR is a non-parametric technique that uses a locally-weighted least squares estimator to smooth scatter plots, and is a spatial innovation that can improve the hedonic difference-in-differences estimates by identifying appropriate treatment zones (Diao et al., 2017; Linden and Rockoff, 2008).

\footnotetext{
${ }^{31}$ The LPR figure was generated using lpoly in STATA. lpoly performs a kernel-weighted local polynomial regression and displays a graph of the smoothed values. We used the Epanechnikov kernel function, rule-of-thumb (ROT) bandwidth estimator, and a polynomial smoothing degree of 0 , meaning local-mean smoothing.
} 


\section{Figure 3.1. Local Polynomial Regression (LPR) and Treatment Zone}

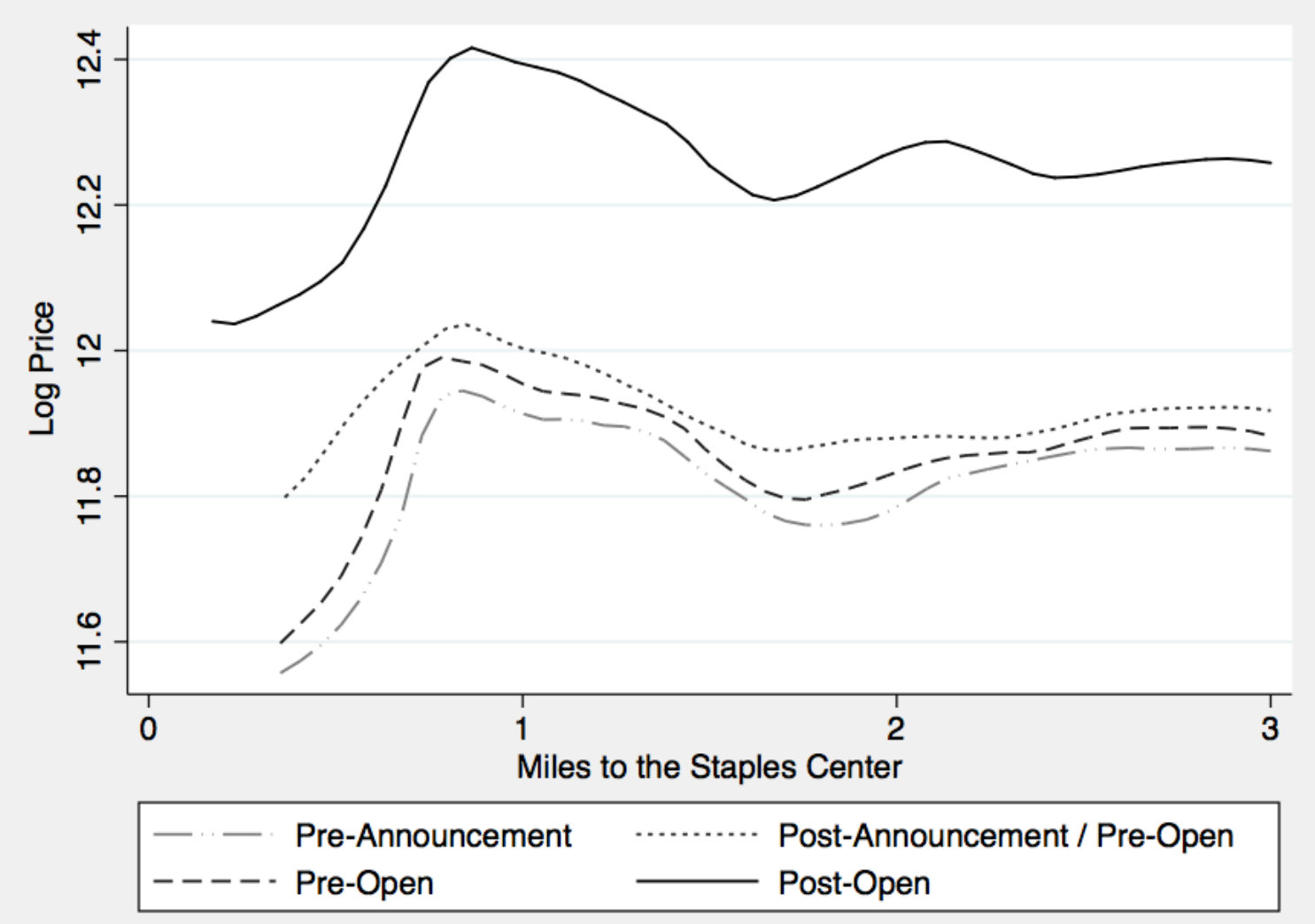

Notes: The figure shows price gradients for the pre-announcement, post-announcement/pre-open, pre-open, and postopen periods with respect to the distance to the Staples Center.

Based on the LPR, Figure 3.1 shows average price gradients for all houses sold during the pre-announcement, post-announcement but pre-opening of the arena, along with the full preopening and post-opening periods with respect to distance to the Staples Center. The figure shows that while single-family home transaction prices follow similar gradients, postannouncement/pre-open and post-open houses sold at a premium, regardless of distance from the Staples Center. Additionally, Figure 3.1 indicates that the most movement occurs within the 2mile distance, with a peak around the 0.75-mile mark. Therefore, we use two different treatment distances, 1 mile and 2 miles, since previous studies have suggested that sports facilities have relatively larger impact areas (Ahlfeldt and Maennig, 2010; Tu, 2005) and there may be distance- 
decaying effects (Feng and Humphreys, 2018). ${ }^{32}$ The use of LPR verifies the use of these distances in our analysis, which are consistent with distances used in many other similar studies.

Additionally, to ensure that there is a distinct difference between treated and control houses, we use a 0.25-mile buffer area around each treatment distance and those houses are excluded from our analysis. For example, a house that is 1 mile from the Staples Center would be treated and only those houses that were at least 1.25 miles away would be considered control observations. This buffer area should ensure that we have a valid control group and are not comparing treated houses to houses that are barely outside of the treatment distance. ${ }^{33}$

The variable of interest is the interaction term between Post and Treated and the coefficient represents the difference-in-differences parameter of interest in this setting. A positive and statistically significant coefficient estimate would suggest that the Staples Center generated (net) positive amenities for nearby homeowners; a negative and statistically significant estimate would mean that residents would be willing to pay more to live farther away from the arena because the negative amenities outweigh the positives.

\subsection{Data}

Los Angeles housing price data come from the firm DataQuick and include transactions from 1995 to 2004 . This timeframe should be sufficient to identify the impact of the Staples Center opening on house prices, as the arena opened in 1999. Additionally, by only including observations through 2004, we alleviate concerns that other subsequent local developments bias our results. For example, the Staples Center is located adjacent to L.A. Live, an entertainment

\footnotetext{
${ }^{32}$ We also use closer treatment distances, such as 0.5 miles and 0.75 miles, and find similar, distance decaying results.

${ }^{33}$ We also conduct analyses without a buffer area and find similar results.
} 
complex of over 5 million square feet. However, the first phase of L.A. Live opened in October, 2007, which is after the timeframe of our study. ${ }^{34}$ Including housing transactions from 1995 to 2004 should be a long enough time period to identify capitalization effects, while also minimizing potential bias from other nearby development projects. ${ }^{35}$

The housing data contain information on the number of bedrooms, square feet, year built, year sold, location (latitude and longitude), and the sale price. Several data cleaning procedures were performed, such as converting house prices to 2000 dollars using the S\&P/Case-Shiller Home Price Index. We only include arms-length single-family home transactions. ${ }^{36}$ Additionally, outliers as well as those observations with missing or zero values were removed. We use approximately the $1^{\text {st }}$ and $99^{\text {th }}$ percentiles as the limits of the bounds for each characteristic of those transactions we retain, as suggested by Humphreys and Nowak (2017) and others. Data on the Staples Center come from the Staples Center's official website and include information on the location of the arena and the opening date.

Using ArcGIS software, we determine the distance from each transacted house to the Staples Center. Once the distances are calculated, we remove observations that are farther than a certain distance from the stadium to avoid boundary discontinuity issues. Since Ahlfeldt and Kavetsos (2014), Ahlfeldt and Maenning (2010), and Tu (2005) suggest a sphere of influence of sports facilities within approximately 3 miles, we limit our control group to houses sold within 3 miles of the Staples Center. ${ }^{37}$ We also determine the distance to the closest open rail station,

\footnotetext{
${ }^{34}$ L.A. Live opened in three different phases between 2007 and 2009 . The first phase included the opening of the Microsoft Theatre, a concert and awards show venue; Xbox Plaza (formerly Microsoft Square), a 40,000 square foot open air space; and an underground parking garage (L.A. Live website).

${ }^{35}$ In sensitivity analysis, we further ensure that we are isolating the impact of the arena by only including observations through 2003.

36 The housing data that we obtained from DataQuick contain indicators for single-family residences and armslength transactions.

${ }^{37}$ We also limit our control group to houses sold within 4 miles, and find similar results.
} 
since several metro stations are located near the Staples Center. Additionally, we determine the distance to the closest highway and to the University of Southern California (USC). ${ }^{38}$ Figure 3.2 presents the spatial distributions of the identifying observations (houses considered Post-Open and Treated using a 1-mile treatment distance) and the control houses. As Figure 3.2 shows, a majority of the identifying and control houses are to the west of the Staples Center on the opposite side of two elevated highways. The area to the east of the arena is zoned as commercial, industrial, or mixed medium residential, which is why almost no single-family residential transactions occurred there.

\footnotetext{
${ }^{38}$ USC (enrollment 44,000) is the only large university in the sample area. It has a 10,000 seat basketball arena on campus. There are also many restaurants, bars, and shops in the nearby area; thus, proximity to the university may affect house prices.
} 
Figure 3.2. Spatial Distributions of the Sample

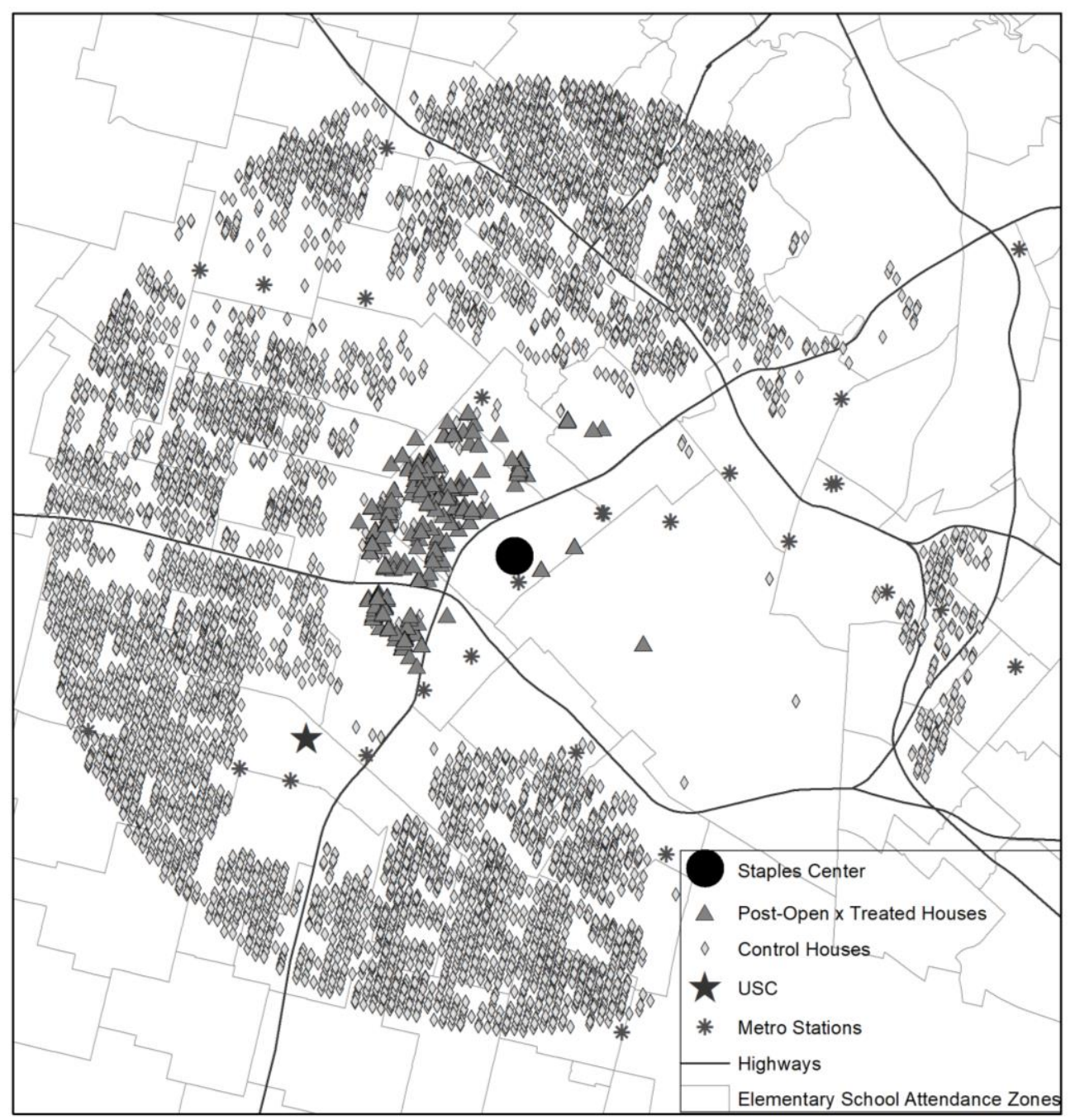

Notes: The figure shows the spatial distributions of the identifying observations (houses considered PostOpen and Treated using a 1-mile treatment distance) and control houses.

Table 3.1 includes the means of key variables for the treated and control house transactions using a treatment distance of 1 mile. We also separate the summary statistics into different subsamples based on when the houses were sold to show how the prices and characteristics of the houses changed over time. Specifically, we present the means for only those houses sold pre-announcement, those sold post-announcement but still pre-open, those sold pre-open, and those sold post-open. As the table indicates, the mean prices and characteristics between treated and control houses sold pre-announcement were very different. For example, on 
average, control houses sold for approximately $\$ 20,533$ more, have more bedrooms and square feet, and are older than treated houses. However, once the location of the Staples Center was announced, the differences between the treated and control houses narrowed. For example, when looking at the means for houses that were sold post-announcement but still pre-open, prices were much more comparable between the two groups, with treated houses selling for approximately $\$ 4,567$ more. Additionally, although the mean prices between the treated and control houses for those sold pre-open were fairly different, they were much more comparable once the arena opened. 
Table 3.1. Means of Key Variables for Treated and Control Groups

\begin{tabular}{|c|c|c|c|c|c|c|c|c|c|c|c|c|}
\hline & \multicolumn{3}{|c|}{ Pre-Announcement } & \multicolumn{3}{|c|}{ Post-Announcement/Pre-Open } & \multicolumn{3}{|c|}{ Pre-Open } & \multicolumn{3}{|c|}{ Post-Open } \\
\hline & $\begin{array}{l}\text { Treated } \\
(\mathrm{n}=171)\end{array}$ & $\begin{array}{c}\text { Control } \\
(\mathrm{n}=2,634)\end{array}$ & $\begin{array}{c}\operatorname{Pr}(|\mathrm{T}|> \\
|t|)\end{array}$ & $\begin{array}{l}\text { Treated } \\
(\mathrm{n}=78)\end{array}$ & $\begin{array}{c}\text { Control } \\
(\mathrm{n}=2,227)\end{array}$ & $\begin{array}{c}\operatorname{Pr}(|T|>> \\
|t|)\end{array}$ & $\begin{array}{l}\text { Treated } \\
(\mathrm{n}=333)\end{array}$ & $\begin{array}{c}\text { Control } \\
(\mathrm{n}=6,457)\end{array}$ & $\begin{array}{c}\operatorname{Pr}(|T|> \\
|t|)\end{array}$ & $\begin{array}{l}\text { Treated } \\
(\mathrm{n}=557)\end{array}$ & $\begin{array}{c}\text { Control } \\
(\mathrm{n}=10,100)\end{array}$ & $\begin{array}{c}\operatorname{Pr}(|\mathrm{T}| \\
>|\mathrm{t}|)\end{array}$ \\
\hline " House Price & $10132,724.70$ & $10153,258.20$ & 0.003 & $10168,379.90$ & $10163,812.50$ & 0.664 & $10146,884.40$ & $1588,350.00$ & 0.020 & $2325,055.30$ & $238,595.10$ & 0.527 \\
\hline Bedrooms & 3.08 & 3.71 & 0.000 & 3.71 & 3.80 & 0.650 & 3.30 & 3.77 & 0.000 & 3.29 & 3.70 & 0.000 \\
\hline $\begin{array}{l}\text { Square Feet } \\
\text { (thous) }\end{array}$ & 2.04 & 2.06 & 0.762 & 2.49 & 2.16 & 0.012 & 2.23 & 2.13 & 0.098 & 2.16 & 2.08 & 0.111 \\
\hline Age & 51.09 & 71.77 & 0.000 & 73.81 & 72.84 & 0.748 & 60.66 & 72.19 & 0.000 & 64.50 & 74.33 & 0.000 \\
\hline $\begin{array}{c}\text { Mi. to } \\
\text { Nearest Hwy }\end{array}$ & 0.29 & 0.64 & 0.000 & 0.32 & 0.65 & 0.000 & 0.30 & 0.65 & 0.000 & 0.29 & 0.65 & 0.000 \\
\hline $\begin{array}{l}\text { Mi. to } \\
\text { Nearest } \\
\text { Metro } \\
\text { Station }\end{array}$ & 0.49 & 1.45 & 0.000 & 0.56 & 1.21 & 0.000 & 0.51 & 1.31 & 0.000 & 0.53 & 1.13 & 0.000 \\
\hline Mi. to USC & 1.74 & 2.30 & 0.000 & 1.73 & 2.33 & 0.000 & 1.73 & 2.30 & 0.000 & 1.74 & 2.42 & 0.000 \\
\hline $\begin{array}{l}\text { Mi. to } \\
\text { Staples } \\
\text { Center }\end{array}$ & 0.56 & 2.35 & 0.000 & 0.64 & 2.37 & 0.000 & 0.60 & 2.35 & 0.000 & 0.59 & 2.34 & 0.000 \\
\hline
\end{tabular}

Notes: The table presents the means and a t-test for difference in the means of the treated houses (using a treatment distance of 1-mile) and control houses (houses more than 1.25-

miles from the arena) during several different time periods. Specifically, houses sold pre-announcement, those sold post-announcement but still pre-open, all those sold pre-open, and those sold post-open. 
Overall, the summary statistics show that while there are differences in prices and characteristics between treated and control houses, the announcement and opening of the arena appeared to narrow the gap. Figure 3.3 contains a month/year parallel trends plot for average inflation-adjusted house prices of the treated and control groups (using a 1-mile treatment distance) with vertical lines at the announcement month/year (May 1997) and open month/year (October 1999), providing further descriptive evidence. ${ }^{39}$ As the figure shows, treated houses that were purchased pre-announcement sold at a discount compared to control houses.

However, the average treated house price increased once the announcement was made in 1997 and followed a similar trend to that of control houses until the Staples Center opened. Once the arena opened in 1999, there appears to be an immediate price decrease, followed by house prices well surpassing pre-open levels. Therefore, the figure shows that house prices followed similar trends pre-announcement and pre-open with changes during the announcement and open year, which suggests that those two events are driving the changes in house prices. Also, while there may have been other shocks to the downtown Los Angeles area during this timeframe, we have no reason to believe that they would have been highly localized in close proximity to the Staples Center.

\footnotetext{
${ }^{39}$ While the arena was initially approved in January 1997, the final vote took place in May 1997 . Therefore, we use May 1997 as the announcement month/year to ensure that we capture the actual finalized date.
} 


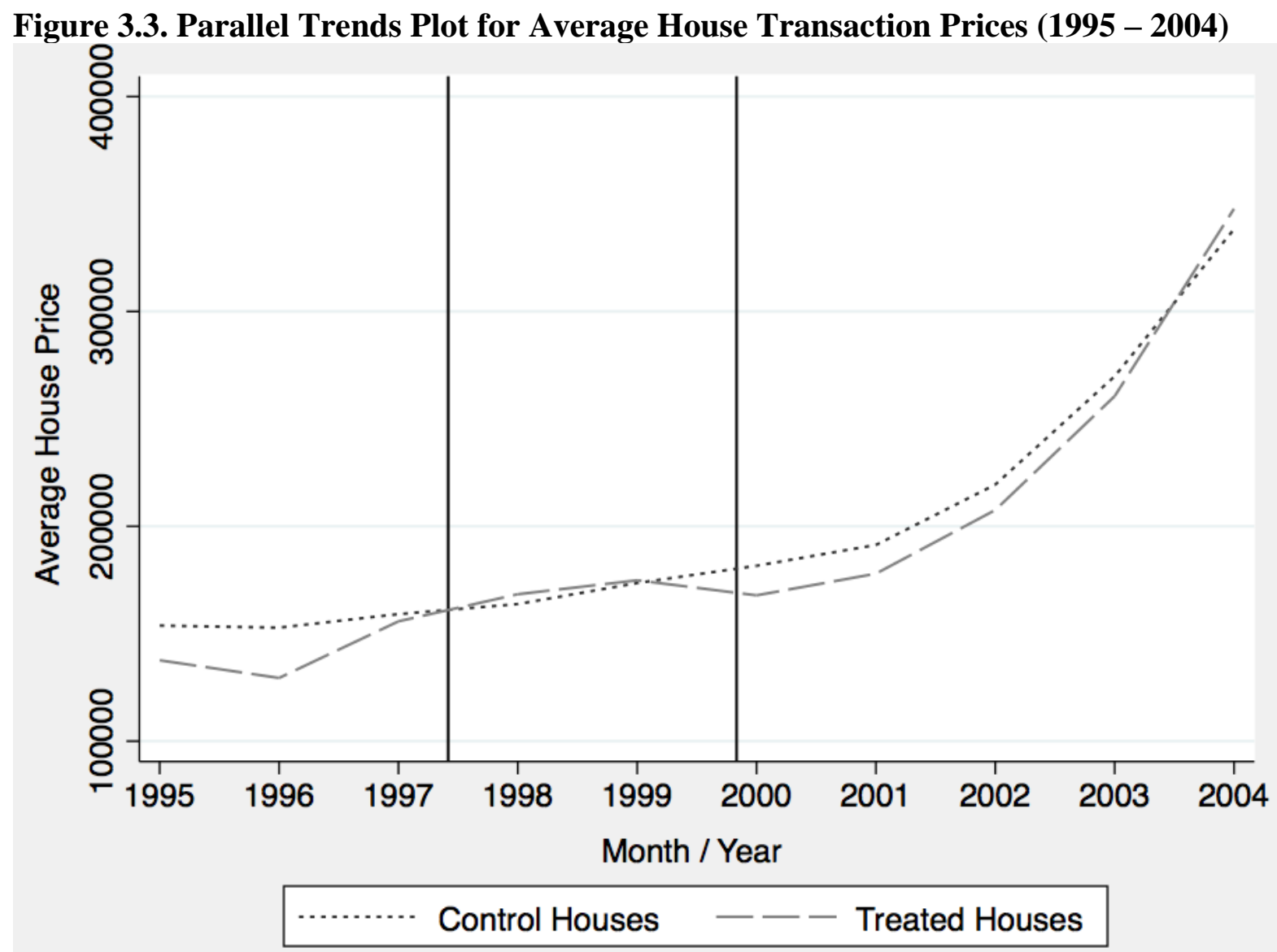

Notes: The figure presents a month/year parallel trends plot for average inflation-adjusted house prices of the treated and control groups (using a 1-mile treatment distance) with vertical lines at the announcement month/year (May 1997) and open month/year (October 1999).

\subsection{Results}

The results of our estimation of the hedonic spatial difference-in-differences models appear in Table 3.2. We estimate four alternative models that include different temporal and spatial treatments to assess the impact of any capitalization effects from the arena. Model 1 includes housing transactions sold before the arena announcement compared to those sold postannouncement but before the new arena opened. Model 2 includes all housing transactions before the new arena announcement compared to houses sold after the announcement. 
Model 3 includes transactions after the announcement but before the new arena opened and those sold after the new arena opened. Model 4 includes all transactions in the sample, where the treatment is the opening of the arena. We employ two different treatment distances: all transactions 1 mile or less from the arena site and another including all transactions 2 miles or less from the arena site. The first group constitutes a subset of the second group. Table 3.2 also shows the number of identifying observations (those considered Post and Treated) for each model and treatment distance.

For completeness, we present the full regression results including the parameter estimates on all house characteristics and location variables in Appendix A8. As Appendix A8 shows, parameter estimates on all house characteristics are statistically different from zero and have their expected signs. For example, additional bedrooms and square footage are associated with prices increases. Appendix A8 also shows that some of our other location variables are statistically significant and thus controlling for them may be important to estimating the true effect of proximity to the Staples Center. 
Table 3.2. Results: Effect of the Staples Center on Log Housing Prices in Los Angeles

\begin{tabular}{|c|c|c|c|c|c|c|c|c|}
\hline & \multicolumn{2}{|c|}{ Model 1} & \multicolumn{2}{|c|}{ Model 2} & \multicolumn{2}{|c|}{ Model 3} & \multicolumn{2}{|c|}{ Model 4} \\
\hline & \multicolumn{2}{|c|}{$\begin{array}{l}\text { Pre-Announcement and Post- } \\
\text { Announcement/Pre-Open }\end{array}$} & \multicolumn{2}{|c|}{$\begin{array}{l}\text { Pre-Announcement and Post- } \\
\text { Announcement }\end{array}$} & \multicolumn{2}{|c|}{$\begin{array}{l}\text { Post-Announcement/Pre-Open and } \\
\text { Post-Open }\end{array}$} & \multicolumn{2}{|c|}{$\begin{array}{l}\text { Pre-Open and } \\
\text { Post-Open }\end{array}$} \\
\hline & $(\leq 1 \mathrm{mi})$. & $(\leq 2 \mathrm{mi})$. & $(\leq 1 \mathrm{mi})$. & $(\leq 2 \mathrm{mi})$. & $(\leq 1 \mathrm{mi})$. & $(\leq 2 \mathrm{mi})$. & $(\leq 1 \mathrm{mi})$. & $(\leq 2 \mathrm{mi})$. \\
\hline \multirow[t]{2}{*}{ Post } & $0.0379 * * *$ & $0.0392 * *$ & $0.753 * * *$ & $0.737 * * *$ & $0.776^{* * *}$ & $0.741 * * *$ & $0.758 * * *$ & $0.733 * * *$ \\
\hline & $(0.0143)$ & $(0.0176)$ & $(0.0134)$ & $(0.0157)$ & $(0.0117)$ & $(0.0137)$ & $(0.0134)$ & $(0.0152)$ \\
\hline \multirow[t]{2}{*}{ Treated } & $-0.124 *$ & $-0.0699 *$ & $-0.230 * * *$ & $-0.0818 * * *$ & $-0.160 * * *$ & $-0.0566 * * *$ & $-0.203 * * *$ & $-0.0779 * * *$ \\
\hline & $(0.0668)$ & $(0.0372)$ & $(0.0412)$ & $(0.0225)$ & $(0.0425)$ & $(0.0219)$ & $(0.0358)$ & $(0.0194)$ \\
\hline \multirow[t]{2}{*}{ Post $\mathrm{x}$ Treated } & $0.116^{* *}$ & $-9.10 \mathrm{e}-05$ & $0.112 * * *$ & $0.0649 * * *$ & -0.00593 & $0.0582 * * *$ & $0.0523 * *$ & $0.0698 * * *$ \\
\hline & $(0.0533)$ & $(0.0251)$ & $(0.0314)$ & $(0.0167)$ & $(0.0321)$ & $(0.0150)$ & $(0.0256)$ & $(0.0128)$ \\
\hline \multicolumn{9}{|l|}{ Housing and Locational } \\
\hline & Yes & Yes & Yes & Yes & Yes & Yes & Yes & Yes \\
\hline School FE & Yes & Yes & Yes & Yes & Yes & Yes & Yes & Yes \\
\hline Year FE & Yes & Yes & Yes & Yes & Yes & Yes & Yes & Yes \\
\hline $\begin{array}{l}\text { Identifying } \\
\text { Observations }\end{array}$ & 78 & 629 & 734 & 4,728 & 557 & 3,347 & 557 & 3,347 \\
\hline Observations & 5,110 & 4,504 & 18,219 & 15,957 & 14,660 & 12,809 & 17,465 & 15,308 \\
\hline R-squared & 0.281 & 0.276 & 0.518 & 0.513 & 0.540 & 0.536 & 0.522 & 0.516 \\
\hline Adjusted R-squared & 0.272 & 0.265 & 0.516 & 0.510 & 0.538 & 0.533 & 0.520 & 0.514 \\
\hline \multicolumn{9}{|l|}{$\begin{array}{l}\text { Robust standard errors } \\
\text { in parentheses }\end{array}$} \\
\hline $\begin{array}{c}* * * \mathrm{p}<0.01, * * \mathrm{p}<0.05 \\
* \mathrm{p}<0.1\end{array}$ & & & & & & & & \\
\hline
\end{tabular}

Notes: All models include housing characteristics; miles to the closest highway, open metro rail station, and USC; elementary school attendance zone fixed effects; and year fixed effects. The coefficient for the interaction term (Post x Treated) in Model 1 using the 2-mile treatment distance is displayed in scientific notation (we have multiplied by 10 to the relevant power to avoid numerous leading zeros). 
In general, the results in Table 3.2 indicate that house prices were higher for all Post transactions in all models relative to transactions in the Pre periods. We also find that houses in close proximity to the arena (Treated) sold for less than houses farther from the arena site.

For the difference-in-differences results, we find that houses in close proximity to the arena sold for more after announcement of the approval of the Staples Center location. Specifically, the interaction term parameter estimates in Model 2 suggest that prices increased 6$11 \%$ for houses in close proximity to the arena purchased post-announcement. Using the mean pre-open house price for a treated home that was sold post-announcement, this represents a $\$ 10,928$ increase in value (using the more conservative 6 percent estimate).

Model 1 provides similar "anticipation" results for the 1-mile treatment distance. However, there were a limited number of transactions that were considered both Post and Treated in this subsample (i.e., 629 identifying observations in Model 1 using a treatment distance of 2 miles compared to 4,728 identifying observations in Model 2), since there was only one year between the announcement and open year. Therefore, while we do find a positive capitalization effect for those houses in close proximity that were purchased post-announcement but still pre-open, Model 2 provides a more complete picture of the "anticipation" effects.

Overall, the results from Model 1 and 2 indicate that there are positive "anticipation" effects. It appears that house prices increased before the Staples Center even opened based on residents positively valuing the potential benefit of living near the arena in the future.

We also find positive effects after the arena opened, as indicated in Model 4. Specifically, house prices increased for those houses that are in close proximity to the arena and were purchased post-open by approximately 5-6\%. Using the mean house price for treated houses sold post-open, this is equivalent to approximately $\$ 12,293$, using the more conservative 5 percent 
estimate. Tu (2004) reported similar evidence for houses near an NFL stadium in Washington, DC.

Examining Model 3, we find similar results to that of Model 4 for the 2-mile treatment distance. While the estimate is statistically insignificant for the 1-mile treatment distance, this is most likely because of the limited number of transactions. For example, there were only 2,305 houses sold post-announcement but still pre-open. Nonetheless, the results in both Model 3 and Model 4 provide evidence that the opening of the arena is positively capitalized into house prices.

Additionally, our "anticipation" and main results suggest that the effect varies by distance to the arena. For example, the capitalization effect appears to become larger as houses come in closer proximity to the Staples Center. Similar distance decaying effects have also been found in related studies (Feng and Humphreys, 2018).

To assess further the capitalization effect, we run a number of robustness checks, with results shown in Table 3.3. First, we estimate models in which we include both the announcement and opening. Specifically, we combine Model 1 and Model 4 from Table 3.2. ${ }^{40}$ By combining these models, we can better determine the timing of the effects, as well as the overall impact. Additionally, to ensure that we are isolating the effect from the opening of the arena, rather than other subsequent local developments, we restrict our data to only include observations through 2003 (these are shown in Model 5). For comparison, Model 6 includes observations through 2004.

\footnotetext{
${ }^{40}$ We combine Model 1 and Model 4 to prevent any double counting of the Post $x$ Treated groups.
} 
Table 3.3. Combined Models Results: Effect of the Staples Center on Log Housing Prices in Los Angeles

\begin{tabular}{|c|c|c|c|c|}
\hline & \multirow{2}{*}{\multicolumn{2}{|c|}{$\begin{array}{c}1995-2003 \\
\text { Model } 5 \\
\end{array}$}} & \multicolumn{2}{|c|}{$1995-2004$} \\
\hline & & & \multirow{2}{*}{\multicolumn{2}{|c|}{$\begin{array}{c}\text { Model } 6 \\
\text { Pre-Announcement and Post-Announcement / } \\
\text { Pre-Open and Pre-Open and Post-Open }\end{array}$}} \\
\hline & \multicolumn{2}{|c|}{$\begin{array}{l}\text { Pre-Announcement and Post-Announcement / } \\
\text { Pre-Open and Pre-Open and Post-Open }\end{array}$} & & \\
\hline & $(\leq 1 \mathrm{mi})$. & $(\leq 2 \mathrm{mi})$. & $(\leq 1 \mathrm{mi})$. & $(\leq 2 \mathrm{mi})$. \\
\hline Post-Announcement / Pre-Open & $\begin{array}{l}0.00945 \\
(0.0130)\end{array}$ & $\begin{array}{l}0.00718 \\
(0.0159)\end{array}$ & $\begin{array}{l}0.00935 \\
(0.0129)\end{array}$ & $\begin{array}{l}0.00649 \\
(0.0157)\end{array}$ \\
\hline Post-Open & $\begin{array}{c}0.507 * * * \\
(0.0136)\end{array}$ & $\begin{array}{l}0.476 * * * \\
(0.0159)\end{array}$ & $\begin{array}{c}0.748 * * * \\
(0.0134)\end{array}$ & $\begin{array}{c}0.723 * * * \\
(0.0158)\end{array}$ \\
\hline Treated & $\begin{array}{c}-0.266 * * * \\
(0.0444)\end{array}$ & $\begin{array}{c}-0.0891 * * * \\
(0.0245)\end{array}$ & $\begin{array}{c}-0.254 * * * \\
(0.0425)\end{array}$ & $\begin{array}{c}-0.0967 * * * \\
(0.0233)\end{array}$ \\
\hline Post-Announcement / Pre-Open x Treated & $\begin{array}{c}0.154 * * * \\
(0.0499)\end{array}$ & $\begin{array}{c}0.0281 \\
(0.0231)\end{array}$ & $\begin{array}{c}0.155 * * * \\
(0.0495)\end{array}$ & $\begin{array}{c}0.0291 \\
(0.0229)\end{array}$ \\
\hline Post-Open x Treated & $\begin{array}{c}0.0949 * * * \\
(0.0334)\end{array}$ & $\begin{array}{c}0.0806 * * * \\
(0.0178)\end{array}$ & $\begin{array}{c}0.117 * * * \\
(0.0322)\end{array}$ & $\begin{array}{c}0.0862 * * * \\
(0.0173)\end{array}$ \\
\hline Housing and Locational Characteristics & Yes & Yes & Yes & Yes \\
\hline School FE & Yes & Yes & Yes & Yes \\
\hline Year FE & Yes & Yes & Yes & Yes \\
\hline $\begin{array}{c}\text { Identifying Observations (Post- } \\
\text { Announcement/Pre-Open x Treated) } \\
\text { Identifying Observations (Post-Open x Treated) }\end{array}$ & $\begin{array}{c}78 \\
440\end{array}$ & $\begin{array}{c}629 \\
2,634\end{array}$ & $\begin{array}{c}78 \\
557\end{array}$ & $\begin{array}{c}629 \\
3,347\end{array}$ \\
\hline $\begin{array}{c}\text { Observations } \\
\text { R-squared } \\
\text { Adjusted R-squared } \\
\text { Robust standard errors in parentheses } \\
* * * \mathrm{p}<0.01, * * \mathrm{p}<0.05, * \mathrm{p}<0.1 \\
\end{array}$ & $\begin{array}{c}13,664 \\
0.456 \\
0.453\end{array}$ & $\begin{array}{c}12,033 \\
0.451 \\
0.447\end{array}$ & $\begin{array}{c}15,767 \\
0.535 \\
0.533\end{array}$ & $\begin{array}{c}13,839 \\
0.530 \\
0.527\end{array}$ \\
\hline
\end{tabular}


Table 3.3 continues to find evidence of positive "anticipation" effects. Specifically, we find that once the announcement was made, houses within 1 mile of the arena sold for approximately $15 \%$ more in both Model 5 and Model 6 . We also find that, even after controlling for these anticipation effects, house prices also increased after the arena opened. When we only include observations through 2003 (Model 5), we find that house prices increased 8-9\%. This is in comparison to when we include observations through 2004 (Model 6), in which it appears that house prices increased $8-11 \%$. While the magnitudes of the estimates when we extend our timeframe are relatively larger (which is consistent with our parallel trends plot), there do not appear to be any other local developments that may be biasing our results. Overall, our results indicate that there is a positive effect from both the announcement, as well as the opening.

\subsection{Conclusion}

In our analysis, we examine the impact of the Staples Center on property values in Los Angeles. This analysis is one of the first to look at a high-intensity use facility that is home to four professional sports teams and used for many concerts and other events, resulting in almost daily use by thousands of people. To deal with potential bias arising from locational amenities and disamenities generated by sports facilities, we implement hedonic difference-in-differences models. Additionally, we use a novel local polynomial regression approach to verify the most appropriate treatment distances, and we control for other locational attributes that previous research has omitted. Despite the high-intensity of use, which could have negative capitalization effects due to congestion and noise, our results indicate that the announcement of the Staples Center is positively capitalized into house prices. Specifically, we find that the announcement of the Staples Center increased property values 6-11\%. We also find that houses in close proximity 
that were purchased after the Staples Center opened sold at a premium; the opening of the arena increased property values by $5-6 \%$.

In addition to the capitalization effect from the opening of the arena, our results reveal important "anticipation" effects of the announcement of the arena location in 1997. In other words, nearby house prices increased after the announcement of the new arena due to anticipation of the positive future benefits from a new sports facility. This suggests that the positive valuation of the new facility was partially realized before it opened. At the same time, it is also important to note that the local area prior to the announcement and construction of the arena contained low-income apartments housing approximately 250 people, primarily minority residents (Rivera, 1999). This area was razed during the construction of the arena and replaced with parking lots and a parking structure. However, the displacement of 250 residents is not likely to change the purchase price of a house by a substantial amount. At a minimum, our "anticipation" effects are the net average impacts considering both the announcement of the amenity (the Staples Center) and removal of a potential disamenity (older, low-income housing). The importance of "anticipation" effects has also been analyzed in the context of other types of urban development (Hyun and Milcheva, 2019).

The Staples Center was primarily built using private financing. If public funds were used, then the narrative behind the benefits may be different. For example, if we estimate the impact of the increase in house prices across all treated houses sold post-opening using the $6 \%$ estimated increase, we find a net increase of a little over $\$ 9$ million in total local housing values. Although this impact is a conservative estimate because it only considers houses that were sold, it is considerably lower than the $\$ 375$ million cost of building the arena. While we find that the opening of a sports facility increased nearby property values, using public funds to finance 
similar projects may not be justified, which has also been suggested in other studies (Coates et al., 2006).

Overall, the results of this study using data from Los Angeles are comparable to those using data from other cities. For example, Ahlfeldt and Kavetsos (2014) and Ahlfeldt and Maennig (2010) found that a new sports facility increased property values by $15 \%$ and $7.5 \%$ in London and Berlin, respectively. Finding comparable results is important given that this is the first study to consider the construction of a facility with such intensive and frequent use. It is also important because of the different housing markets that are being examined. For example, there is some friction built into the Los Angeles housing market because of Proposition $13 .{ }^{41}$ Thus, we provide additional important evidence that sports facilities, along with other large entertainment centers (the Staples Center also hosts concerts and other events), may be a positive amenity for nearby homeowners. This is especially important for sports facilities or large entertainment centers that are heavily utilized and those located in extremely dense, or populated areas.

One potential new project for which our findings may be applicable is SoFi Stadium, the home of the Los Angeles Rams and Chargers of the National Football League (NFL), which just opened on August 23, 2020. The $\$ 2.6$ billion venue is located in Inglewood, California, a city in southwestern Los Angeles County. While the stadium was built with private funding, it is still important to understand the impacts that the stadium could have on the nearby community. Our results provide insight into how residents in similar communities, such as Inglewood, may value living near a new sports facility or other types of urban development. Based on our findings,

\footnotetext{
${ }^{41}$ Adopted by California voters in 1978, Proposition 13 rolled back most real estate assessments to 1975 market value levels, mandates a property tax rate of one percent, and allows assessments to rise by no more than two percent per year until the next sale. Houses are only reassessed once a house is sold. This creates a "lock-in" effect since residents pay less in taxes if they remain in their current house than they would if they moved to a different house of the same value.
} 
perhaps some of the benefit has already been built into higher housing prices due to the "anticipation effect." 


\section{Appendix}

\section{A1. Example House and Matching Strata}

\begin{tabular}{|c|c|c|}
\hline & Example House & Matching Strata \\
\hline \multicolumn{3}{|c|}{ House Specific Variables } \\
\hline Bedrooms & 3 & $3-4$ \\
\hline Bathrooms & 3 & $3-4$ \\
\hline Square Feet & 1,725 & $1,634-2,263$ \\
\hline Acres & 0.5 & $0.42-0.61$ \\
\hline Age & 14 & $10-20$ \\
\hline \multicolumn{3}{|l|}{ Spatial Control } \\
\hline $\begin{array}{l}\text { Commuting Zone } \\
\text { (Exact match) }\end{array}$ & North Central & North Central \\
\hline \multicolumn{3}{|c|}{$\begin{array}{l}\text { Notes: This table includes an example of a treated house included in our analysis and the matching } \\
\text { strata for each variable (using Specification 2). In this example, a non-treated house would only be } \\
\text { considered a match to the example house if it had } 3-4 \text { bedrooms, } 3-4 \text { bathrooms, } 1,634-2,263 \\
\text { square feet, } 0.42 \text { - } 0.61 \text { acres, was } 10-20 \text { years old, and was in the north central commuting zone. If } \\
\text { even one variable was not in the matching strata, it would not be considered a match. }\end{array}$} \\
\hline
\end{tabular}




\section{A2. Hedonic Results: Effect of Drilling Activity on Log Housing Prices in West Virginia} (2006-2015)

\section{Specification 1}

(1)

No. of Wells Within 4 Miles
Groundwater Dependent
No. of Wells Within 4 Miles
x Groundwater Dependent

No. of Wells Within 4 Miles

x

\begin{abstract}
Bedrooms
\end{abstract}
$0.0310 * * *$

(0.0064)

$0.149^{* * * *}$

(0.0069)

$0.000301^{* * *}$

$0.000301^{* * *}$

Square Feet

$(0.0000)$

$0.00548^{* * * *}$

(0.0009)

$-0.00687 * * *$

(0.0002)

Acres

Age
$-0.0034$

(0.0052)

$0.0310 * * *$

(0.0064)

$0.149 * * *$

(0.0069)

(0.0000)

$0.00550 * * *$

(0.0009)

-0.00687 ***

(0.0002)
Specification 2

(1)

(2)

$-0.00123$

$-0.00119$

$(0.0011)$

$(0.0011)$

$-0.000579$

(0.0150)

$-0.00118$

$(0.0050)$

$0.0281 * * *$

$0.0281 * * *$

(0.0063)

(0.0063)

$0.131^{* * * *}$
$(0.0069)$

$0.131 * * *$

(0.0069)

$0.000296 * * *$

$0.000297 * * *$

(0.0000)

$(0.0000)$

$0.00612 * * *$

$0.00612 * * *$

(0.0009)

(0.0009)

\begin{tabular}{ccccc} 
Age & $-0.00687 * * *$ & $-0.00687 * * *$ & $-0.00647 * *$ & $-0.00647 * * *$ \\
& $(0.0002)$ & $(0.0002)$ & $(0.0002)$ & $(0.0002)$ \\
\hline Observations & 15,165 & 15,165 & 15,165 & 15,165 \\
R-squared & 0.576 & 0.576 & 0.6 & 0.6 \\
$\begin{array}{c}\text { Adjusted R-squared } \\
\text { Standard errors in } \\
\text { parentheses }\end{array}$ & 0.575 & 0.575 & 0.599 & 0.599 \\
*** $\mathrm{p}<0.01, * * \mathrm{p}<0.05, *$ \\
$\mathrm{p}<0.1$
\end{tabular}

Notes: All models include housing characteristics; miles to the closest MSA, major city, and interstate; mining employment; county fixed effects and year fixed effects. Additionally, the Specification 2 models control for tract-level characteristics, including population density and the average number of bedrooms, bathrooms, square feet, acres, and age for all single-family houses in the tract in which the house is located. 


\section{A3. CEM County and Year-of-Sale Interaction Results: Effect of Drilling Activity on Log Housing Prices in West Virginia (2006-2015)}

\begin{tabular}{|c|c|c|c|c|}
\hline & \multicolumn{2}{|c|}{ Specification 1} & \multicolumn{2}{|c|}{ Specification 2} \\
\hline & $(1)$ & (2) & (1) & $(2)$ \\
\hline No. of Wells Within 4 Miles & $\begin{array}{r}-0.00732 \\
(0.0068)\end{array}$ & $\begin{array}{l}-0.00758 \\
(0.0069)\end{array}$ & $\begin{array}{c}-0.00238^{*} \\
(0.0013)\end{array}$ & $\begin{array}{r}-0.00207 \\
(0.0013)\end{array}$ \\
\hline Groundwater Dependent & & $\begin{array}{c}0.0288 \\
(0.0482)\end{array}$ & & $\begin{array}{l}0.0395 * \\
(0.0238)\end{array}$ \\
\hline $\begin{array}{l}\text { No. of Wells Within } 4 \text { Miles x } \\
\text { Groundwater Dependent }\end{array}$ & & $\begin{array}{c}0.0055 \\
(0.0173)\end{array}$ & & $\begin{array}{r}-0.00751 \\
(0.0056)\end{array}$ \\
\hline Observations & 1,378 & 1,378 & 6,424 & 6,424 \\
\hline R-squared & 0.603 & 0.603 & 0.606 & 0.607 \\
\hline Adjusted R-squared & 0.59 & 0.589 & 0.599 & 0.599 \\
\hline
\end{tabular}

Standard errors in parentheses

$* * * \mathrm{p}<0.01, * * \mathrm{p}<0.05, * \mathrm{p}<0.1$

Notes: All models include housing characteristics, miles to the closest MSA, major city, and interstate, mining employment, and a county and year-of-sale interactions. Additionally, the Specification 2 models control for tract-level characteristics, including population density and the average number of bedrooms, bathrooms, square feet, acres, and age for all single-family houses in the tract in which the house is located, since these variables were not used in matching. To control for the matched pairs, CEM weights are also included in the regressions. 


\section{A4. CEM Census Tract Fixed Effect Results: Effect of Drilling Activity on Log Housing Prices in West Virginia (2006-2015)}

Specification 1

(1)

$$
-0.00968
$$$$
\text { (0.0067) }
$$

No. of Wells Within 4 Miles

Groundwater Dependent

No. of Wells Within 4 Miles x

Groundwater Dependent
Specification 2

(1)

(2)

0.00288

(0.0022)

(0.0021)

$0.0459^{*}$

(0.0259)

(0.0535)

$-0.0156^{* * *}$

(0.0059)
Observations

R-squared

Adjusted R-squared

$\begin{array}{ll}1,378 & 1,378 \\ 0.616 & 0.616 \\ 0.598 & 0.597\end{array}$

6,424

0.616

0.616

0.605

Standard errors in parentheses $* * * \mathrm{p}<0.01, * * \mathrm{p}<0.05, *$ $\mathrm{p}<0.1$

Notes: All models include housing characteristics, miles to the closest MSA, major city, and interstate, mining employment, and census tract fixed effects. Additionally, the Specification 2 models control for tract-level characteristics, including population density and the average number of bedrooms, bathrooms, square feet, acres, and age for all single-family houses in the tract in which the house is located, since these variables were not used in matching. To control for the matched pairs, CEM weights are also included in the regressions. 


\section{A5. CEM Two Year Lags Results: Effect of Drilling Activity on Log Housing Prices in West Virginia (2006-2015)}

Specification 1

(1)
Specification 2

\begin{tabular}{|c|c|c|c|c|}
\hline No. of Wells Within 4 Miles & $\begin{array}{l}-0.0158 \\
(0.0103)\end{array}$ & $\begin{array}{l}-0.0180 * \\
(0.0105)\end{array}$ & $\begin{array}{c}-0.00346^{* *} \\
(0.0015)\end{array}$ & $\begin{array}{r}-0.00329 * * \\
(0.0015)\end{array}$ \\
\hline Groundwater Dependent & & $\begin{array}{c}0.0193 \\
(0.0575)\end{array}$ & & $\begin{array}{c}0.0524 * * \\
(0.0260)\end{array}$ \\
\hline $\begin{array}{l}\text { No. of Wells Within } 4 \text { Miles } \\
\text { x Groundwater Dependent }\end{array}$ & & $\begin{array}{c}0.0256 \\
(0.0220)\end{array}$ & & $\begin{array}{l}-0.00602 \\
(0.0079)\end{array}$ \\
\hline Observations & 1,043 & 1,043 & 5,636 & 5,636 \\
\hline R-squared & 0.61 & 0.612 & 0.592 & 0.593 \\
\hline $\begin{array}{c}\text { Adjusted R-squared } \\
\text { Standard errors in } \\
\text { parentheses } \\
* * * \mathrm{p}<0.01, * * \mathrm{p}<0.05, * \\
\mathrm{p}<0.1\end{array}$ & 0.601 & 0.602 & 0.589 & 0.589 \\
\hline
\end{tabular}

(1)

(2)

(2)

0.0193

(0.0079) pairs, CEM weights are also included in the regressions. 
A6. Full Results: All Houses Combined (Both Gold and Expo Stations)

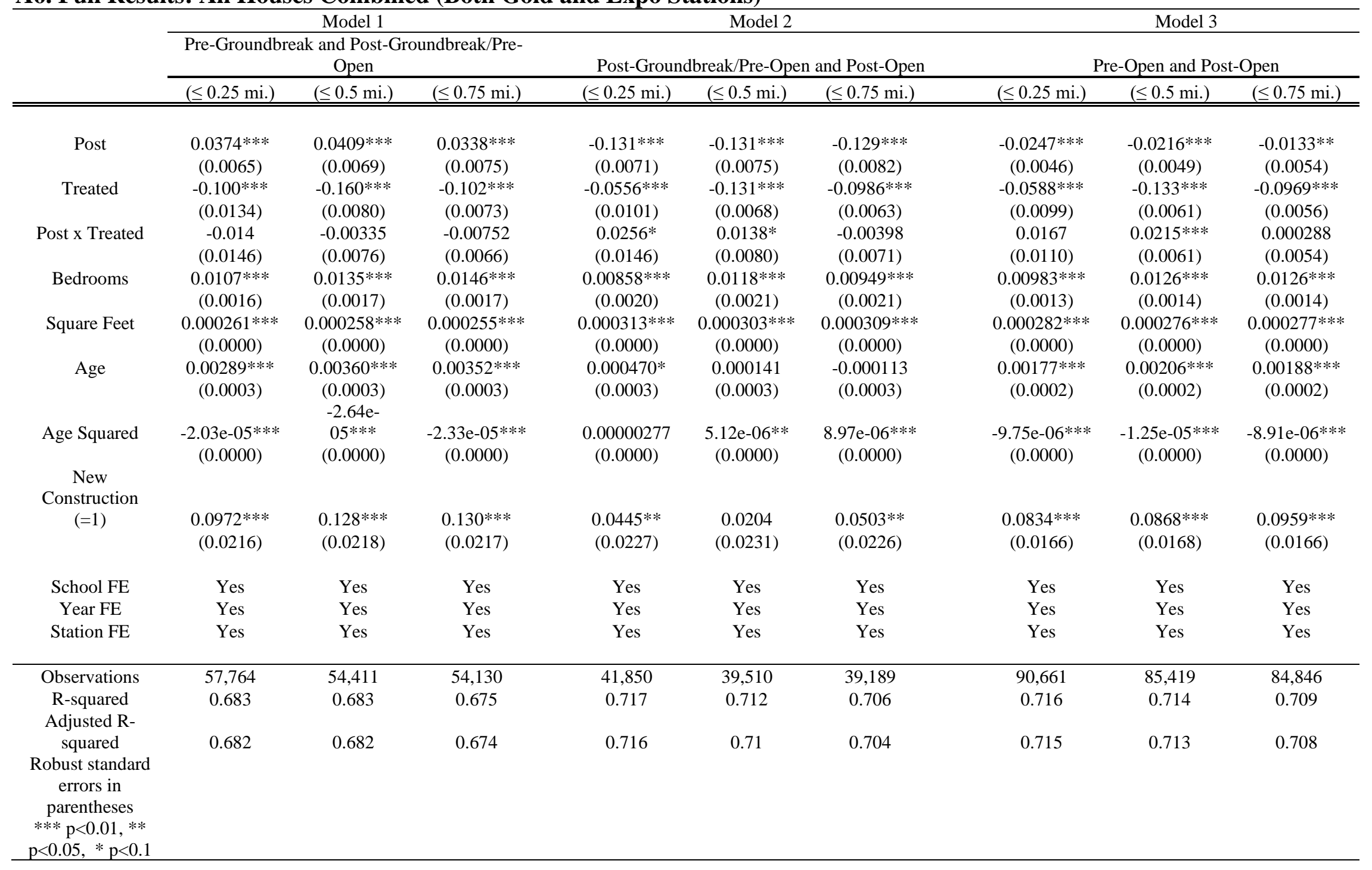


A7. Full Results (Continuous Distance): All Houses Combined (Both Gold and Expo Stations)

\begin{tabular}{|c|c|c|c|}
\hline & $\begin{array}{c}\text { Model } 1 \\
\text { Pre-Groundbreak and Post- } \\
\text { Groundbreak/Pre-Open }\end{array}$ & $\begin{array}{c}\text { Model } 2 \\
\text { Post-Groundbreak/Pre-Open and } \\
\text { Post-Open }\end{array}$ & $\begin{array}{c}\text { Model } 3 \\
\text { Pre-Open and Post- } \\
\text { Open } \\
\end{array}$ \\
\hline Post & $\begin{array}{c}0.0285^{* * * *} \\
(0.00896)\end{array}$ & $\begin{array}{l}-0.131 * * * \\
(0.00978)\end{array}$ & $\begin{array}{c}-0.0105 \\
(0.00689)\end{array}$ \\
\hline Mi. to Station & $\begin{array}{l}0.157 * * * \\
(0.00656)\end{array}$ & $\begin{array}{l}0.142 * * * \\
(0.00887)\end{array}$ & $\begin{array}{l}0.151 * * * \\
(0.00532)\end{array}$ \\
\hline Post $\mathrm{x}$ Mi. to Station & $\begin{array}{c}0.00834 \\
(0.00793)\end{array}$ & $\begin{array}{c}0.00149 \\
(0.00857)\end{array}$ & $\begin{array}{l}-0.00713 \\
(0.00649)\end{array}$ \\
\hline Bedrooms & $\begin{array}{c}0.0126 * * * \\
(0.00149)\end{array}$ & $\begin{array}{c}0.00994 * * * \\
(0.00182)\end{array}$ & $\begin{array}{c}0.0114 * * * \\
(0.00123)\end{array}$ \\
\hline Square Feet & $\begin{array}{c}0.000261 * * * \\
(2.34 \mathrm{e}-06)\end{array}$ & $\begin{array}{c}0.000311 * * * \\
(2.90 \mathrm{e}-06)\end{array}$ & $\begin{array}{c}0.000282 * * * \\
(1.94 \mathrm{e}-06)\end{array}$ \\
\hline Age & $\begin{array}{c}0.00327 * * * \\
(0.000255)\end{array}$ & $\begin{array}{l}-0.000123 \\
(0.000238)\end{array}$ & $\begin{array}{c}0.00172 * * * \\
(0.000183)\end{array}$ \\
\hline Age Squared & $\begin{array}{c}-2.20 \mathrm{e}-05^{* * *} \\
(2.27 \mathrm{e}-06)\end{array}$ & $\begin{array}{c}8.72 \mathrm{e}-06 * * * \\
(2.03 \mathrm{e}-06)\end{array}$ & $\begin{array}{c}-8.18 \mathrm{e}-06 * * * \\
(1.60 \mathrm{e}-06)\end{array}$ \\
\hline New Construction $=1$ & $\begin{array}{c}0.120^{* * *} \\
(0.0196)\end{array}$ & $\begin{array}{c}0.0450 * * \\
(0.0207)\end{array}$ & $\begin{array}{c}0.0925^{* * * *} \\
(0.0151)\end{array}$ \\
\hline School FE & $\mathrm{Y}$ & $\mathrm{Y}$ & $\mathrm{Y}$ \\
\hline Year FE & $\mathrm{Y}$ & $\mathrm{Y}$ & $\mathrm{Y}$ \\
\hline Station FE & $\mathrm{Y}$ & $\mathrm{Y}$ & $\mathrm{Y}$ \\
\hline Constant & $\begin{array}{c}12.22^{* * * *} \\
(0.0308)\end{array}$ & $\begin{array}{c}12.10^{* * *} \\
(0.0259)\end{array}$ & $\begin{array}{l}12.07 * * * \\
(0.0210)\end{array}$ \\
\hline $\begin{array}{c}\text { Observations } \\
\text { R-squared } \\
\text { Adjusted R-squared } \\
\text { Robust standard errors in } \\
\text { parentheses } \\
* * * \mathrm{p}<0.01, * * \mathrm{p}<0.05, * \mathrm{p}<0.1\end{array}$ & $\begin{array}{c}68,096 \\
0.673 \\
0.672\end{array}$ & $\begin{array}{c}49,820 \\
0.706 \\
0.705\end{array}$ & $\begin{array}{c}107,302 \\
0.708 \\
0.707\end{array}$ \\
\hline
\end{tabular}


A8. Full Results: Effect of the Staples Center on Log Housing Prices in Los Angeles

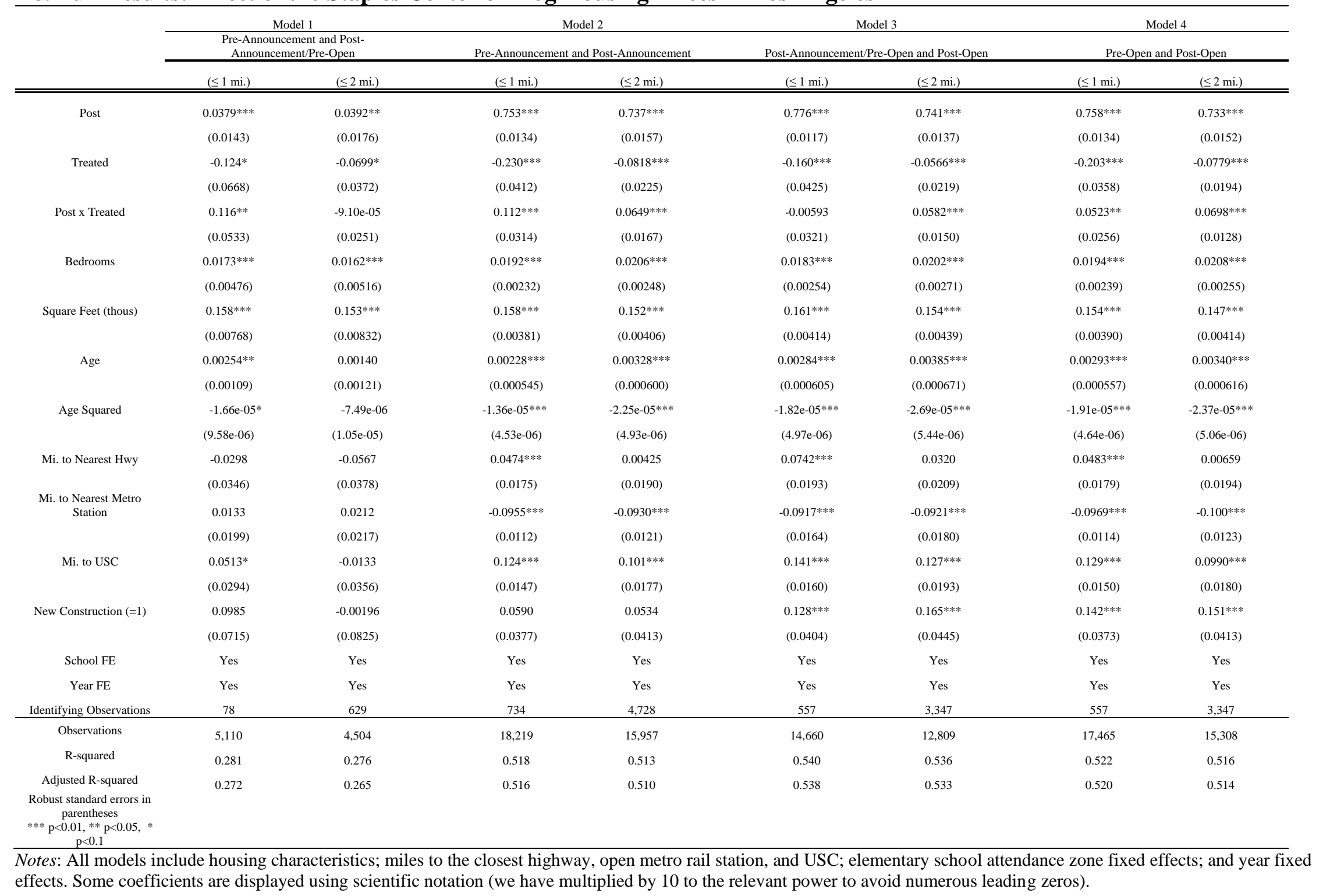




\section{References}

Abdalla, C., Drohan, J., Rahm, B., Jacquet, J., Becker, J., Collins, A., Klaiber, A., Poe, G., \& Grantham, D. (2012). Water's Journey through the Shale Gas Drilling and Production Processes in the Mid-Atlantic Region. Penn State Extension: College of Agricultural Sciences, Pennsylvania State University.

Agha, N. \& Coates, D. (2015). A compensating differential approach to valuing the social benefit of minor league baseball. Contemporary Economic Policy, 33(2): 285-299.

Ahlfeldt, G. \& Kavetsos, G. (2012). Outlook, progress and challenges of stadium evaluation. In Maennig, W., Zimbalist, A. (Eds.), International handbook on the economics of mega sporting events (pp. 279-294). Cheltenham, England: Edward Elgar Publishing.

Ahlfeldt, G. \& Kavetsos, G. (2014). Form or function? The effect of new sports stadia on property prices in London. Journal of the Royal Statistical Society, 177(Part 1): 169-190.

Ahlfeldt, G. \& Maennig, W. (2009) Arenas, arena architecture and the impact on location desirability: The case of 'olympic arenas' in Prenzlauer Berg, Berlin. Urban Studies, 46(7): $1343-1362$.

Ahlfeldt, G. \& Maennig, W. (2010). Impact of sports arena on land values: Evidence from Berlin. Annals of Regional Science, 44: 205-227.

Akbar, D., Rolfe, J., \& Kabir, Z. (2013). Predicting impacts of major projects on housing prices in resource based towns with a case study application to Gladstone, Australia. Resources Policy, 38: 481-489.

Bae, C.H., Jun, C., \& Park, H., (2003). The Impact Of Seoul's Subway Line 5 On Residential Property Values. Transport Policy, 10(2): 85-94.

Bajic, V. (1983). The Effect Of A New Subway Line On Housing Prices In Metropolitan Toronto. Urban Studies, 20: 147-158.

Balthrop, A. \& Hawley, Z. (2017). I can hear my neighbors' fracking: The effect of natural gas production on housing values in Tarrant County, TX. Energy Economics, 61: 351-362.

Barth, J. (2013). The economic impact of shale gas development on state and local economies: Benefits, costs, and uncertainties. New Solutions: A Journal of Environmental and Occupational Health Policy, 23(1): 85-101.

Baum-Snow, N., \& Kahn, M.E. (2000). The Effects Of New Public Projects To Expand Urban Rail Transit. Journal of Public Economics, 77: 241-263. 
Betz, M., Partridge, M., Farren, M., \& Lobao, L. (2015). Coal mining, economic development, and the natural resources curse. Energy Economics, 50: 105-116.

Black, S. (1999). Do better schools matter? Parental valuation of elementary education. Quarterly Journal of Economics, 114(2): 577-599.

Black, K., McCoy, S., \& Weber, J. (2017). When Externalities Are Taxed: The Effects and Incidence of Pennsylvania's Impact Fee on Shale Gas Wells. Journal of the Association of Environmental and Resource Economists, 5(1): 107-153.

Blackwell, M., Iacus, S., King, G., \& Porro, G. (2009). CEM: coarsened exact matching in Stata. Stata Journal, 9(4): 524-546.

Brown, J., Fitzgerald, T., \& Weber, J. (2016). Capturing Rents from Natural Resource Abundance: Private Royalties from US Onshore Oil Gas Production. Resource and Energy Economics, 46: 23-38.

Brown, J. (2014). Production of natural gas from shale in local economies: a resource blessing or curse? Federal Reserve Bank of Kanas City Economic Review, 99(1): 5-29.

Boarnet, M., Chakrabarti, S., Bostic, R., Rodnyansky, S., Morrison-Hawkins, B., SantiagoBartolomei, R., \& Wang, X. (2015). Housing Affordability And Transit-Oriented Development In Los Angeles: A Challenge And An Opportunity. Working Paper.

Boarnet, M. \& Chalermpong, S. (2001). New highways, house prices, and urban development: A case study of toll roads in Orange County, CA. Housing Policy Debate, 12(3): 575-605.

Boslett, A., Guilfoos, T., \& Lang, C. (2016). Valuation of expectations: A hedonic study of shale gas development and New York's moratorium. Journal of Environmental Economics and Management, 77: 14-30.

Boslett, A., Guilfoos, T., \& Lang, C. (2019). Valuation of the External Costs of Unconventional Oil and Gas Development: The Critical Importance of Mineral Rights Ownership. Journal of the Association of Environmental and Resource Economists, 6(3): 531-561.

Boslett, A. \& Hill E. (2019). Shale gas transmission and housing prices. Resource and Energy Economics, 57: 36-50.

Bowes, D. \& Ihlanfeldt, K. (2001). Identifying The Impacts Of Rail Transit Stations On Residential Property Values. Journal of Urban Economics, 50(1): 1-25.

Boxall, P., Chan, W., \& McMillan, M. (2005). The impact of oil and natural gas facilities on rural residential property values: a spatial hedonic analysis. Resource and Energy Economics, 27(3): 248-269. 
Carlino, G. and Coulson, N. (2004). Compensation differentials and the social benefits of the NFL. Journal of Urban Economics, 56: 25-50.

Camins-Esakov, J., \& Vandegrift, D. (2018). Impact of a light rail extension on residential property values. Research in Transportation Economics, 67: 11-18.

Case, K., \& Shiller, R. (1989). The efficiency of the market for single-family homes. American Economic Review, 79(1): 125-137.

Chikish, Y., Humphreys, B., \& Nowak, A. (2019a). Sports arenas, teams and property values: Temporary and permanent shocks to local amenity flows. Journal of Regional Analysis \& Policy, 49(1): 1-12.

Chikish, Y., Humphreys, B., Liu, C., \& Nowak, A. (2019b). Sports-led tourism, spatial displacement, and hotel demand. Economic Inquiry, 57(4): 1859-1874.

Clark, D., Michelbrink, L., Allison, T., \& Metz, W. (1997). Nuclear Power Plants and Residential Housing Prices. Growth and Change, 28(4): 496-519.

Coates, D. (2007). Stadiums and arenas: Economic development or economic redistribution? Contemporary Economic Policy, 25: 565-577.

Coates, D. \& Humphreys, B. (2003). The effect of professional sports on earnings and employment in the services and retail sectors in US cities. Regional Science and Urban Economics, 33: 175-198.

Coates, D., Humphreys, B., \& Zimbalist, A. (2006). Compensating differentials and the social benefits of the NFL: A comment. Journal of Urban Economics, 60: 124-131.

Coates, D. \& Matheson, V. (2011). Mega-events and housing costs: Raising the rent while raising the roof? Annals of Regional Science, 46: 119-137.

Cohen, J. \& Coughlin, C. (2009). Changing Noise Levels and Housing Prices Near the Atlanta Airport. Growth and Change, 40(2): 287-313.

Collins, A. \& Nkansah, K. (2015). Divided Rights, Expanded Conflict: Split Estate Impacts on Surface Owner Perceptions of Shale Gas Drilling. Land Economics, 91(4): 688-703.

Damm, D., Lerman, S.R., \& Lerner-Lam, E. (1980). Response Of Urban Real Estate Values In Anticipation Of The Washington Metro. Journal of Transport Economics and Policy, 14: 315336.

Debrezion, G., Pels, E., \& Rietveld, P. (2011). The Impact Of Rail Transport On Real Estate Prices: An Empirical Analysis Of The Dutch Housing Market. Urban Studies, 48(5): 997-1015. 
Dehring, C., Depken, C., \& Ward, M. (2007). The impact of stadium announcements on residential property values: Evidence from a natural experiment in Dallas-Fort Worth. Contemporary Economic Policy, 25: 627-638.

Delgado, M., Guilfoos, T., \& Boslett, A. (2016). The cost of unconventional gas extraction: A hedonic analysis. Resource and Energy Economics, 46: 1-22.

Dewees, D.N. (1976). The Effect Of A Subway On Residential Property Values In Toronto. Journal of Urban Economics, 3: 357-369.

Diao, M., Leonard, D., \& Sing, T. (2017). Spatial-Difference-In-Differences Models For Impact Of New Mass Rapid Transit Line On Private Housing Values. Regional Science and Urban Economics, 67: 64-77.

Douglas, S. \& Walker, A. (2016). Coal Mining and the Resource Curse in the Eastern United States. Journal of Regional Science, 57(4): 568-590.

Drohan, P., Finley, J., Roth, P., Schuler, T., Stout, S., Brittingham, M., \& Johnson, N. (2012). Perspectives from the field: Oil and gas impacts on forest ecosystems: findings gleaned from the 2012 Goddard Forum at Penn State University. Environmental Practice, 14(4): 394-399.

Drukker, AJ., Gayer, T., \& Gold, AK. (2020). Tax-exempt municipal bonds and the financing of professional sports stadiums. National Tax Journal, 73(1): 157-9.

Esposito, A. \& Wimmer, P. (2003). The Boomtown Phenomenon: Effects on Housing, Transportation and the Economic Development of the Region. In: LaLone, M., Wimmer, P., \& Hartle, A. (Eds.) The Radford Arsenal: Impacts and Cultural Change in an Appalachian Region, 2nd Ed., Brightside Press.

Feng, X. \& Humphreys, B. (2012). The impact of professional sports facilities on housing values: Evidence from census block group data. City, Culture \& Society, 3(3): 189-200

Feng, X. \& Humphreys, B. (2018). Assessing the economic impact of sports facilities on residential property values: A spatial hedonic approach. Journal of Sports Economics, 19(2): 188-210.

Ferreira, S., Liu, H., \& Brewer, B. (2018). The Housing Market Impacts of Wastewater Injection Induced Seismicity Risk. Journal of Environmental Economics and Management, 92: 251-269.

Fesselmeyer, E., \& Liu, H. (2018). How Much Do Users Value A Network Expansion? Evidence From The Public Transit System In Singapore. Regional Science and Urban Economics, 71: 4661.

Fetzer, T. (2014). Fracking Growth. Center for Economic Performance Discussion Paper 1,278. 
Feyrer, J., Mansure, E., \& Sacerdote, B. (2017). Geographic Dispersion of Economic Shocks: Evidence from the Fracking Revolution, 107(4): 1313-1334.

Fitzgerald, T. \& Rucker, R. (2016). US Private Oil and Natural Gas Royalties: Estimates and Policy Relevance. Open Energy Review, 40: 3-15.

Frohlich, C. (2012). Two-year survey comparing earthquake activity and injection-well locations in the Barnett Shale, Texas. Proceedings of the National Academy of Sciences, 109(35): 1393413938.

Gatzlaff, D., \& Smith, M. (1993). The Impact Of The Miami Metrorail On The Value Of Residences Station Locations. Land Economics, 69: 54-66.

Gerton, M., Hartley, P., Medlock, K., \& Temzelides, T. (2017). Employment impacts of upstream oil and gas investment in the United States. Energy Economics, 62: 171-180.

Gibbons, S., \& Machin, S. (2005). Valuing Rail Access Using Transport Innovations. Journal of Urban Economics, 57: 148-169.

Glaeser, E., \& Gottlieb, J. (2009). The Wealth of Cities: Agglomeration Economies and Spatial Equilibrium in the United States. Journal of Economic Literature, 47(4): 983-1028.

Gopalakrishnan, S., \& Klaiber, H. A. (2013). Is the shale energy boom a bust for nearby residents? Evidence from housing values in Pennsylvania. American Journal of Agricultural Economics, 96(1): 43-66.

Haggerty, J., Gude, P., Delorey, M., \& Rasker, R. (2014). Long-Term Effects of Income Specialization in Oil and Gas Extraction: The US West, 1980-2011. Energy Economics, 45: 186195.

Hainmueller, J. (2012). Entropy Balancing for Causal Effects: A Multivariate Reweighting Method to Produce Balanced Samples in Observational Studies. Political Analysis, 20: 25-46.

Hajkowicz, A., Heyenga, S., \& Moffat, K. (2011). The relationship between mining and socioeconomic well being in Australia's regions. Resources Policy, 36: 30-38.

Han, L., Wei YD., Wu, Y., \& Tian, G. (2019). Analyzing housing prices in Shanghai with open data: Amenity, accessibility and urban structure. Cities, 91: 165-179.

Harleman, M. \& Weber, J. (2017). Natural resource ownership, financial gains, and governance: The case of unconventional gas development in the UK and the US. Energy Policy, 111: 281296.

Hartley, P., Medlock, K., Temzelides, T., \& Zhang, X. (2015). Local employment impact from competing energy sources: Shale gas versus wind generation in Texas. Energy Economics, 49: 610-619. 
Heintzelman, M., \& Tuttle, C. (2012). Values in the Wind: A Hedonic Analysis of Wind Power Facilities. Land Economics, 88(3): 571-588.

Hou, Y. (2017). Traffic congestion, accessibility to employment, and housing prices: A study of single-family housing market in Los Angeles County. Urban Studies, 54(15): 3423-3445.

Huang, H. \& Humphreys, B. (2014). New sports facilities and residential housing markets. Journal of Regional Science, 54(4): 629-663.

Huang, H., Humphreys, B., \& Zhou, L. (2016). Do urban casinos affect nearby neighbourhoods? Evidence from Canada. Papers in Regional Science, 97(3): 757-784.

Hughes, D. (2014). Drilling Deeper: A Reality Check on U.S. Government Forecasts for a Lasting Tight Oil \& Shale Gas Boom. Post-Carbon Institute Paper.

Humphreys, B. (2019). Should the construction of new professional sports facilities be subsidized? Journal of Policy Analysis and Management, 38(1): 264-270.

Humphreys, B. \& Nowak, A. (2017). Professional Sports Facilities, Teams and Property Values: Evidence from NBA Team Departures. Regional Science and Urban Economics, 66: 39-51.

Humphreys, B. \& Pyun, H. (2018). Professional sporting events and traffic: Evidence from US cities. Journal of Regional Science, 58(5): 869-886.

Humphreys, B. \& Zhou, L. (2015). Sports facilities, agglomeration, and public subsidies. Regional Science and Urban Economics, 54: 60-73.

Hyun, D. \& Milcheva, S. (2019). Spatio-temporal effects of an urban development announcement and its cancellation on house prices: A quasi-natural experiment. Journal of Housing Economics, 43: 23-36.

Iacus, S., King, G., \& Porro, G. (2011). Multivariate matching methods that are monotonic imbalance bounding. Journal of American Statistical Association, 106(493): 345-361.

Kavetsos, G. (2012). The impact of the London Olympics announcement on property prices. Urban Studies, 49: 1453-1470.

Iacus, S., King, G., \& Porro, G. (2012). Causal Inference without balance checking: coarsened exact matching. Political Analysis, 20(1): 1-24.

Jackson, R., Vengosh, A., Darrah, T., Warner, N., Down, A., Poreda, R., Osborn, S., Zhao, K., \& Karr, J. (2013). Increased stray gas abundance in a subset of drinking water wells near Marcellus Shale gas extraction. Proceedings of the National Academy of Sciences, 110(28): 11250-11255.

James A. \& Aadland, D. (2011). The Curse of Natural Resources: An Empirical Investigation of 
U.S. Counties. Resource and Energy Economics, 33(2): 440-453.

James, A. \& James, J. (2014). A canary near a gas well: Gas booms and housing market busts in Colorado. Working Paper.

Kargbo, D., Wilhelm, R., \& Campbell, D. (2010). Natural gas plays in the Marcellus Shale: challenges and potential opportunities. Environmental Science and Technology, 44(15): 56795684.

Kelsey, T., Shields, M., Ladlee, J., \& Ward, M. (2011). Economic Impacts of Marcellus Shale in Pennsylvania: Employment and Income in 2009. Penn State Extension and Penn College.

King, G. \& Nielsen, R. (2019). Why Propensity Scores Should Not Be Used for Matching. Political Analysis, 27(4): 435-454.

Klaiber, H. A. (2008). Valuing open space in a locational equilibrium model of the Twin Cities. (Ph.D. dissertation) Retrieved from North Carolina State University.

Komarek, T. (2018). Crime and Natural Resource Booms: Evidence from Unconventional Natural Gas Production. The Annals of Regional Science, 61(1): 113-137.

Kuminoff, N., Parmeter, C., \& Pope, J. (2010). Which Hedonic Models Can We Trust to Recover the Marginal Willingness to Pay for Environmental Amenities? Journal of Environmental Economics and Management, 60(3): 145-160.

Kuminoff, N. \& Pope, J. (2014). Do “capitalization effects" for public goods reveal the public's willingness to pay? International Economic Review, 55(4): 1227-1250.

L.A. Metro - a. https://www.metro.net/news/ridership-statistics/. Last accessed February, 2019.

L.A. Metro - b. https://www.metro.net/news/facts-glance/. Last accessed February, 2019.

Landis, J., Cervero, R., Guhathukurta, S., Loutzenheiser, D., \& Zhang, M. (1995). Rail Transit Investments, Real Estate Values, And Land Use Change: A Comparative Analysis Of Five California Rail Transit Systems. Institute of Urban and Regional Studies, University of California at Berkeley, Berkeley, CA, 48.

Li, S., Yang, J., Qin, P., \& Chonabayashi, S. (2016). Wheels Of Fortune: Subway Expansion And Property Values In Beijing. Journal of Regional Science, 56(5): 792-813.

Lin, J.-J., \& Hwang, C.H. (2003). Analysis Of Property Prices Before And After The Opening Of The Taipei Subway System. The Annals of Regional Science, 38: 687-704.

Linden, L. \& Rockoff, J. (2008). Estimates of the impact of crime risk on property values from Megan's Law. American Economic Review, 98(3): 1103-1127. 
Lim, S. (2018). Does Shale Energy Development Mean More Crime? The Case of the Bakken Oil Boom. Growth and Change, 49(3): 413-441.

Litovitz, A., Curtright, A., Abramzon, S., Burger, N., \& Samaras, C. (2013). Estimation of regional air-quality damages from Marcellus Shale natural gas extraction in Pennsylvania. Environmental Research Letters, 8(1): 1-8.

Locke, SL. (2019). Estimating the impact of Major League Baseball games on local air pollution. Contemporary Economic Policy, 37(2): 236-244.

Lutz, B., Lewis, A., \& Doyle, M. (2013). Generation, transport, and disposal of wastewater associated with Marcellus Shale gas development. Water Resources Research, 49(2): 647-656.

Maguire, K. \& Winters, J. (2017). Energy Boom and Gloom? Local Effects of Oil and Natural Gas Drilling on Subjective Well-Being. Growth and Change, 48(4): 590-610.

Marcos-Martinez, R., Measham, T., \& Fleming-Muñoz, D. (2019). Economic impacts of early unconventional gas mining: Lessons from the coal seam gas industry in New South Wales, Australia. Energy Policy, 125: 338-346.

Matheson, V. (2019). Is there a case for subsidizing sports stadiums?. Journal of Policy Analysis and Management, 38(1): 271-277.

McKenzie, L., Witter, R., Newman, L., \& Adgate, J. (2012). Human health risk assessment of air emissions from development of unconventional natural gas resources. Science of the Total Environment, 424: 79-87.

McMillen, D. \& McDonald, J. (2004). Reaction of house prices to a new rapid transit line: Chicago's midway line, 1983-1999. Real Estate Economics, 32(3): 463-486.

McMillen, D. \& Redfearn, C. (2010). Estimation and Hypothesis Testing for Nonparametric Hedonic House Price Function. Journal of Regional Science, 50(3): 712-733.

Mense, A. (2017). A Real Options Approach to Amenity Valuation: The Role of Uncertainty and Risk Aversion. Journal of Regional Science, 58(2): 315-329.

Metro Developer. https://developer.metro.net/introduction/gis-data/download-gis-data/. Last accessed February, 2019.

Metro Primary Resources. metroprimaryresources.info. Last accessed February, 2019.

Mohammad, Sara I., Graham, Daniel J., Melo, Patricia C., Anderson, \& Richard J. (2013). A Meta-Analysis Of The Impact Of Rail Projects On Land And Property Values. Transportation Research Part A: Policy and Practice, 50: 158-170. 
Montolio, D. \& Planells-Struse, S. (2016). How time shapes crime: The temporal impacts of football matches on crime. Regional Science and Urban Economics, 61: 99-113.

Muehlenbachs, L., Spiller, E., \& Timmins, C. (2013). Shale Gas Development and the Costs of Groundwater Contamination Risk. Resources for the Future Discussion Paper, RFF DP 12-40REV 12-40.

Muehlenbachs, L., Spiller, E., \& Timmins, C. (2015). The Housing Market Impacts of Shale Development. The American Economic Review, 105(12): 3633-3659.

Munasib, A., \& Rickman, D. (2015). Regional economic impacts of the shale gas and tight oil boom: A synthetic control analysis. Regional Science and Urban Economics, 50: 1-17.

Nelson, A. (1992). Effects Of Elevated Heavy-Rail Transit Stations On House Prices With Respect To Neighborhood Income. Transportation Research Record, 1359: 127-132.

Olmstead, S., Muehlenbachs, L., Shih, J., Chu, Z., \& Krupnick, A. (2013). Shale gas development impacts on surface water quality in Pennsylvania. Proceedings of the National Academy of Sciences, 110(13): 4962-4967.

Palmquist, R. (2005). Property Value Models. In: Maler, K-G. \& Vincent, J. (Eds.) Handbook of Environmental Economics, vol. 2, North Ireland Press, Amsterdam.

Papyrakis, E. (2017). The Resource Curse - What Have We Learned from Two Decades of Intensive Research: Introduction to the Special Issue. Journal of Development Studies, 53(2): 175-185.

Papyrakis, E. \& Gerlagh, R. (2007). Resource Abundance and Economic Growth in the United States. European Economic Review, 51(4): 1011-1039.

Paredes, D., Komarek, T., \& Loveridge, S. (2015). Income and Employment Effects of Shale Gas Extraction Windfalls: Evidence from the Marcellus Region. Energy Economics, 47: 112120.

Patrick, C. \& Mothorpe, C. (2017). Demand for new cities: Property value capitalization of municipal incorporation. Regional Science and Urban Economics, 67: 78-89.

Plaschke, B. (1997). Arena means downtown will party when it's 1999. Los Angeles Times, www.latimes.com.

Propheter, G. (2019a). Do urban sports facilities have unique social costs? An analysis of eventrelated congestion on police response time. International Journal of Urban Sciences, 24(2): 271281.

Propheter, G. (2019b). Estimating the effect of sports facilities on local area commercial rents: Evidence from Brooklyn's Barclays Center. Journal of Sports Economics, 20(1): 91-114. 
Pyun, H. (2019). Exploring causal relationship between Major League Baseball games and crime: a synthetic control analysis. Empirical Economics, 57(1): 365-383.

Rahm, B., Bates, J., Bertoia, L., \& Riha, S. (2013). Wastewater Management and Marcellus Shale Gas Development: Trends, Drivers, and Planning Implications. Journal of Environmental Management, 120: 105-113.

Redfearn, C. (2009). How Informative Are Average Effects? Hedonic Regression And Amenity Capitalization In Complex Urban Housing Markets. Regional Science and Urban Economics, 39: 297-306.

Rich, A., Grover, J., \& Sattler, M. (2014). An exploratory study of air emissions associated with shale gas development and production in the Barnett Shale. Journal of the Air \& Waste Management Association, 64(1): 61-72.

Rickman, D., Wang, H., \& Winters, J. (2017). Is Shale Development Drilling Holes in the Human Capital Pipeline? Energy Economics, 62: 283-290.

Rivera, C. (1999). Staples Center's displaced have new homes and new worries. Los Angeles Times, www.latimes.com.

Roback, J. (1982). Wages, Rents, and the Quality of Life. Journal of Political Economy, 90(6): 1257-1278.

Rosen, S. (1974). Hedonic Prices and Implicit Markets - Product Differentiation in Pure Competition. Journal of Political Economy, 82(1): 34-55.

Sadayuki, T. (2018). Measuring The Spatial Effect Of Multiple Sites: An Application To Housing Rent And Public Transportation In Tokyo, Japan. Regional Science and Urban Economics, 70: 155-173.

Stephens, H. \& Deskins, J. (2018). Economic Distress and Labor Market Participation. American Journal of Agricultural Economics, 100(5): 1336-1356.

Stephens, H. \& Partridge M. (2011). Do Entrepreneurs Enhance Economic Growth in Lagging Regions? Growth and Change, 42(4): 431-465.

Stephens, H., Partridge M., \& Faggian A. (2013). Innovative entrepreneurship and economic growth in lagging regions. Journal of Regional Science, 53(5): 778-812.

Stephens, H. \& Weinstein, W. (2019). Household valuation of energy development in amenityrich regions. Growth and Change, 50(4): 1375-1410. 
Taylor, L. (2003). The hedonic method. In: Champ, A., Boyle, K., \& Brown, T. (Eds.) A Primer on Nonmarket Valuation. The Economics of Non-Market Goods and Resources, vol. 3, Springer, Dordrecht.

Tsvetkova, A. \& Partridge, M. (2016). Economics of modern energy boomtowns: do oil and gas shocks differ from shocks in the rest of the economy? Energy Economics, 59: 81-95.

Tu, C. (2005). How does a new sports stadium affect housing values? The Case of FedEx Field. Land Economics, 81(3): 379-396.

U.S. Bureau of Economic Analysis (BEA). https://www.bea.gov/. Last accessed September 2018.

U.S. Bureau of Labor Statistics (BLS). https://www.bls.gov/. Last accessed September 2018.

U.S. Census Bureau (Census). https://www.census.gov/. Last accessed September 2018.

U.S. Department of Energy (DOE). (2013). Natural Gas From Shale: Questions and Answers. Office of Fossil Energy. https://www.energy.gov/sites/prod/files/2013/04/f0/complete_brochure.pdf.

U.S. Energy Information Administration (EIA-A). West Virginia: Natural Gas Gross Withdrawals and Production. https://www.eia.gov/dnav/ng/ng_prod_sum_dc_swv_mmcf_m.htm. Last accessed December 2017.

U.S. Energy Information Administration (EIA-B). West Virginia: State Profile and Energy Estimates. https://www.eia.gov/state/analysis.php?sid=WV. Last accessed September 2018.

U.S. Geological Survey (USGS). How much gas is in the Marcellus Shale? http://energy.usgs.gov. Last accessed September 2018.

van Holm, EJ. (2019). Minor stadiums, major effects? Patterns and sources of redevelopment surrounding Minor League Baseball stadiums. Urban Studies, 56(4): 672-688.

Wagner, G., Komarek, T., \& Martin, J. (2017). Is The Light Rail “Tide” Lifting Property Values? Evidence From Hampton Roads, VA. Regional Science and Urban Economics, 65: 2537.

Wang, Z. \& Krupnick, A. (2013). A Retrospective Review of Shale Gas Development in the United States: What Led to the Boom? Economics of Energy and Environmental Policy, 4(1): 517.

Weber, J. (2012). The Effects of a Natural Gas Boom on Employment and Income in Colorado, Texas, and Wyoming. Energy Economics, 34(5): 1580-1588. 
Weber, J. (2014). A Decade of Natural Gas Development: The Makings of a Resource Curse? Resource and Energy Economics, 37: 168-183.

Weber, J., Burnett, W., \& Xiarchos, I. (2016). Broadening Benefits from Natural Resource Extraction: Housing Values and Taxation of Natural Gas Wells as Property. Journal of Policy Analysis and Management, 35(3): 587-614.

Weinstein, A. (2014). Local Labor Market Restructuring in the Shale Boom. The Journal of Regional Analysis and Policy, 44(1): 71-92.

Weinstein, A. \& Partridge, M. (2011). The Economic Value of Shale Natural Gas in Ohio. Swank Program in Rural-Urban Policy Summary and Report.

Weinstein A., Partridge, M., \& Tsvetkova, A. (2018). Follow the money: Aggregate, sectoral and spatial effects of an energy boom on local earnings. Resources Policy, 55: 196-209.

Wheaton, W. (1990). Vacancy, search, and prices in a housing market matching model. Journal of Political Economy, 98(6): 1270-1292. 